\title{
DEVELOPMENT OF NOVEL BREAST CANCER-TARGETED SPECT IMAGING PEPTIDES BY PHAGE DISPLAY
}

\section{A Dissertation Presented to the Faculty of the Graduate School University of Missouri-Columbia}

In Partial Fulfillment of the Requirements for the Degree Doctor of Philosophy

\section{by \\ BENJAMIN M. LARIMER}

Dr. Susan L. Deutscher, Dissertation Supervisor

MAY 2014 



\section{ACKNOWLEDGMENTS}

I w ould like to begin by thanking my mentor, Sue. Sue has been instrumental in my development as a scientist, and I would not be the scientist I am today without her. She ha senerously s hared he $r$ kno wledge, $\mathrm{p}$ atience and t ime, and for that I a $\mathrm{m}$ tr uly grateful. I want to thank my committee for taking time to offer me advice and direction, and Dr. Jurisson in particular, who was kind en ough to accept me as a trainee on her training grant.

Also I w ould like to thank everyone in the lab. Marie has not only provided me with advice and help in the lab, but she has also coached me through a marathon and is always there to give me advice in life. Jess has helped me critique all of my ideas and taught me useful skills in the lab, and even discussed a little friendly bit of politics. Mette has made the graduate student journey together with me and has provided great insight and shared in my graduate student frustrations.

I want to thank my family, especially my parents, for teaching me that hard work and perseverance pay off. They have never hesitated to do anything to help me, and I will never be able to repay them.

Most importantly, I want to thank my wife and best friend, Carissa. A common theme with me is that patience is required, and she has had endless patience. She knows when I n eed s upport a nd when I need to be pu shed, and I can't thank her e nough. I couldn't have asked for anything more. 


\section{TABLE OF CONTENTS}

Acknowledgements........................................................

List of Tables and Figures................................................. vii

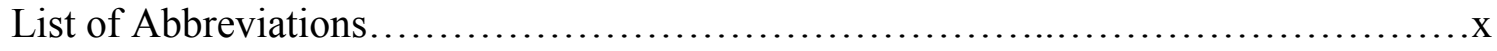

Abstract.............................................................................

Chapter 1

Introduction...................................................................

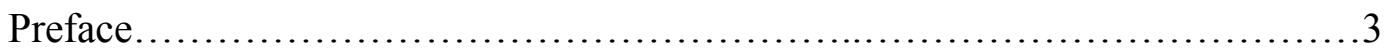

Cancer................................................................. 5

Breast Cancer...................................................................

Detection.........................................................11

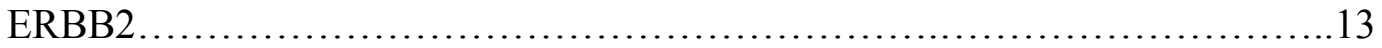

Phage Display.................................................... 17

Peptides............................................................ 21

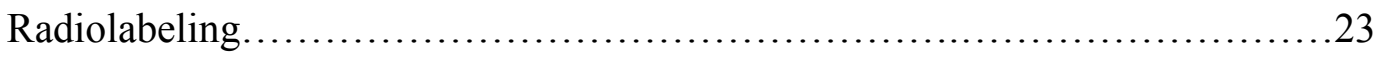

Conclusion.......................................................25

Chapter 2

Affinity Maturation of an ERBB2-Targeted S PECT Imaging P eptide by In Vivo Phage

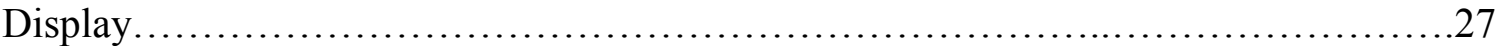


Introduction.

Materials and Methods................................................ 33

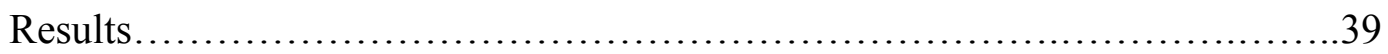

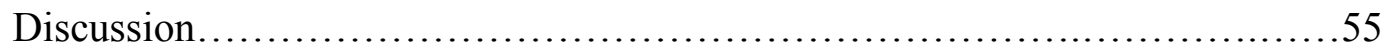

Conclusion......................................................6 61

Acknowledgments................................................6 63

Chapter 3

Identification of a $\mathrm{P}$ eptide $\mathrm{f}$ rom In $\mathrm{V}$ ivo Bacteriophage Display with $\mathrm{H}$ omology $\mathrm{t}$ o EGFL6, A Candidate Tumor Vasculature Ligand in Breast Cancer...................65

Introduction....................................................... 67

Materials and Methods............................................... 71

Results......................................................... 77

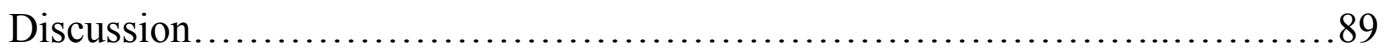

Conclusion..................................................... 95

Acknowledgments................................................97

\section{Chapter 4}

Development of a $\mathrm{P}$ eptide $\mathrm{b}$ y $\mathrm{P}$ hage $\mathrm{D}$ isplay $\mathrm{f}$ or $\mathrm{S}$ PECT Imaging of $\mathrm{R}$ esistanceSusceptible Breast Cancer....................................................99

Introduction..................................................... 101

Methods and Materials.............................................. 107

Results........................................................ 113

Discussion.......................................................... 127 
Conclusion.

Acknowledgments.

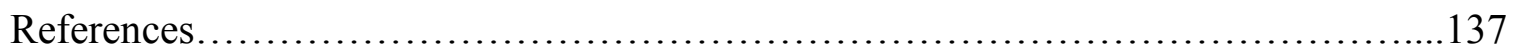

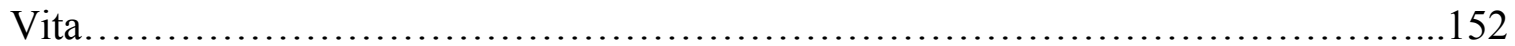




\section{LIST OF TABLES AND FIGURES}

Table

$2.1{ }^{111}$ In-DOTA-1-D03 Biodistribution................................... 47

2.2 Radiolabeled Tumor:Organ Uptake Ratios.............................48

2.3 Radiolabeled Peptide Kidney Retention...............................52

\section{Figure}

2.1 Phage cell binding ratio of MDA-435/184A.1 cells....................40

2.2 Phage ELISA for ERBB2 affinity..................................42

2.3 Confocal microscopy of KCCYSL and $2^{\text {nd }}$ generation peptides............43

2.4 Radiolabeled cell binding of KCCYSL, 1-D03 and 3-G03 ...............45

$2.5^{111}$ In-DOTA-1-D03 and KCCYSL biodistribution comparison...............51

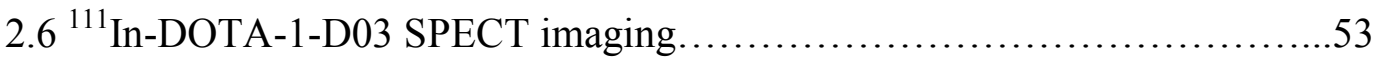

3.1 EGFL6 and 3-G03 sequence comparison............................ 78

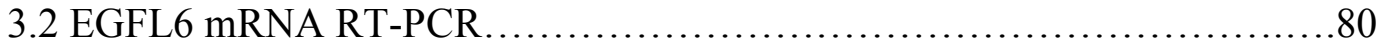

3.3 EGFL6 protein immunoblot....................................... 81

3.4 EGFL6 peptide confocal microscopy $\ldots \ldots \ldots \ldots \ldots \ldots \ldots \ldots \ldots \ldots \ldots \ldots . \ldots \ldots 2$ 
$3.5{ }^{111}$ In-DOTA-EGFL6 cell binding. .84

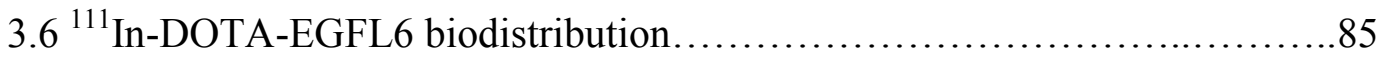

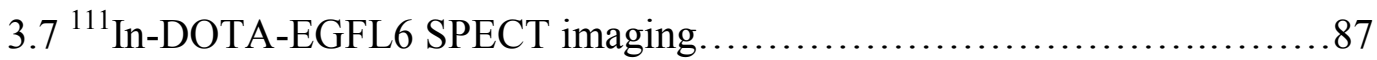

4.1 BT-474 in vivo selection sequences and cell binding.....................114

4.2 Peptide 51 confocal microscopy and flow cytometry.....................116

$4.3^{111}$ In-DOTA-51 cell binding competition assay...........................118

$4.4{ }^{111}$ In-DOTA-51 biodistribution.........................................119

$4.5{ }^{111}$ In-DOTA-51 SPECT imaging ........................................... 120

4.651 and V1 in vitro cell binding assays.................................122

4.7 Truncated 51 Cell Binding Comparison...................................125 


\section{LIST OF ABBREVIATIONS}

\%ID/g: percent injected dose per gram

184A.1: normal breast epithelial cell line

ATP: adenosine triphosphate

BLAST: basic local alignment search tool

BSA: bovine serum albumin

BT-474: human breast cancer cell line

CB-TE2A: 4,11-bis(carboxymethyl)-1,4,8,11-

tetraazabicyclo[6.6.2] hexadecane

CHAPS: 3-[(3-cholamidopropyl)dimethylammonio]-1-propanesulfonate

cpIII: coat protein III

CPM: counts per minute

DMEM: Dulbelcco's modified eagle medium

DOTA: 1,4,7,10-tetraazacyclododecane-1,4,7,10-tetraacetic acid

DOTATOC: DOTA labeled octreotide

DTPA: diethylenetriaminepentaacetic acid

$\mathrm{EC}_{50}$ : half maximal effective concentration

EDTA: ethylenediaminetetraacetic acid

EGF: epidermal growth factor 
EGFL6: epidermal growth factor-like ligand 6

EGFR: epidermal growth factor receptor

ELISA: enzyme-linked immunosorbent assay

FBS: fetal bovine serum

FDG: fluorodeoxyglucose

FI: fluorescent intensity

FMOC: fluorenylmethyloxycarbonyl

HEPES: 2-[4-(2-hydroxyethyl)piperazin-1-yl]ethanesulfonic acid

HER: human epidermal growth factor receptor

HYNIC: 6-hydrazinonicatonic acid

$\mathrm{IC}_{50}$ : half maximal inhibitory concentration

$\mathrm{KeV}$ : kiloelectron volt

LDS: lauryl doodecyl sulfate

MDA-MB-435: human breast cancer cell line

NOTA: 1,4,7-triazacyclononane-triacetic acid

Nrp1: Neuropilin-1

OV-CAR-3: human ovarian cancer cell line

PBS: phosphate buffered saline

PC-3: human prostate cancer cell line

PET: positron emission tomography

ReCCMSH: rhenium-cyclized melanocyte stimulating hormone peptide 
RP HPLC: reverse phase-high pressure liquid chromatography

SAROTUP: scanner and relator of target unrelated peptides

SCID: severe combined immunodeficient

SDS PAGE: sodium dodecyl sulfate polyacrylaminde gel electrophoresis

SPECT: single photon emission computed tomography

TBS: Tris buffered saline

TBST: Tris buffered saline and tween-20

TETA: 1,4,8,11-tetraazacyclotetradecane-1,4,8,11-tetraacetic acid

$\mathrm{TU} / \mathrm{mL}$ : tetracycline transducing units per milliliter

TU: tetracycline transducing units 


\title{
DEVELOPMENT OF NOVEL BREAST CANCER- \\ TARGETED SPECT IMAGING PEPTIDES BY PHAGE \\ DISPLAY
}

By: Benjamin M. Larimer

Dr. Susan L. Deutscher. Dissertation Supervisor

\begin{abstract}
Breast c ancer is the second leading cause of cancer and c ancer-related mortality among women. The survival rate of the malignancy declines considerably as the disease progresses, $w$ hich $n$ ecessitates $r$ apid discovery and $t$ reatment [1]. $\mathrm{C}$ urrent $\mathrm{m}$ ethods of detection including mammograms and breast exams have been successful, however they have limita tions [2]. B oth technologies r ely on the de tection of a large mass of $\mathrm{c}$ ells, which is not conducive to identifying aggressive cancer at an early stage. Additionally, these $m$ ethodologies cannot provide bi ological information that $m$ ay dictate the us of specific targeted therapies. As treatment for breast cancer continues to progress towards xiv
\end{abstract}


therapies targeted at specific carcinogenic antigens, an ability to detect these antigens will improve $\mathrm{p}$ atient $\mathrm{c}$ are a nd $\mathrm{p}$ revent in effective tr eatment $\mathrm{r}$ egimens. $\mathrm{T}$ argeted $\mathrm{i}$ maging agents not only provide the ability to detect breast cancer, but also allow for simultaneous non-invasive characterization.

The $\mathrm{c}$ hoice of $\mathrm{v}$ ector $\mathrm{f}$ or a ta rgeted ima ging a gent $\mathrm{d}$ ictates its $\mathrm{p}$ robability o $\mathrm{f}$ success. $\mathrm{P}$ eptides pr ovide $\mathrm{s}$ everal $\mathrm{p}$ roperties $\mathrm{t}$ hat $\mathrm{m}$ ake $\mathrm{t}$ hem a $\mathrm{s}$ trong $\mathrm{c}$ andidate $\mathrm{f}$ or imaging agents. A peptide is easily synthesized, and can be conjugated in a site specific manner with a molecule allowing for in vivo detection. For breast cancer detection, the use of a bifunctional chelator allows for binding of a radiometal, which in turn permits clear signal detection at an y depth of tissue $[3,4]$. A ra diolabeled peptide's s mall size provides it with rapid pharmacokinetics and enhanced tumor penetration, allowing for the peptide to quickly reach a tumor and bind, followed by clearance of unbound peptide [4]. This is especially important for radiolabeled imaging a gents, as circulating radionuclide can deliver an unwanted dose of radiation to radiosensitive organs such as the bone [5]. A major drawback of a peptide is its moderate affinity, how ever the use of bacteriophage (phage) display technology allows for the selection of peptides with suitable affinity for in vivo imaging.

Phage display, pioneered by George P. Smith here at the University of Missouri, utilizes the tolerance of phage particles to the insertion of random peptides into its coat proteins in order to select a di splayed peptide with a de sired function [6]. A library of phage particles displaying random peptides can be created by altering the phage genome, allowing for production of up to $10^{9}$ unique peptide sequences. Phages can be incubated 
with a $t$ arget of interest, and onl y those bound recovered. R ecovered $p$ hages a re then propagated in bacteria, creating an enriched subpopulation of phages displaying peptides with the desired function. Phage display can be used to select peptides with affinity for a purified a ntigen in vitro or a gainst $\mathrm{w}$ hole or gans or e ven $\mathrm{t}$ umors in vivo [7-9]. It is hypothesized in this dissertation that novel breast cancer targeted peptides can be selected by phage display for the purpose of imaging human breast tumors in vivo.

Development of a peptide for imaging purposes begins with the choice of a target. In $b$ reast can cer, E RBB2 i s a h ighly i mportant $t$ arget. E RBB2 is a m ember o f t he epidermal growth factor re ceptor (E GFR/ERBB) fa mily of $t$ ransmembrane $r$ eceptors, consisting of EGFR, E RBB2, ERBB3 and ERBB4. ERBB2 is over-expressed in up t o $30 \%$ of breast cancers, and is expressed in almost $90 \%$ of all tumors [10]. Not only is the receptor highly p revalent, but its presence co rrelates with increased a ggressiveness and decreased s urvival $r$ ates [11]. $S$ tability and pr omiscuity o $f E$ RBB2 a ccount $f$ or $i$ ts unfavorable phenotype. The receptor does not have a ligand, and is instead constitutively receptive to dimerization and mitogenic signaling [12]. Additionally, a dimer containing ERBB2 is highly stable and transmits signals longer th an other members of its family. Fortunately, h ighly s table cel $1 \mathrm{~s}$ urface $\mathrm{r}$ eceptors ar e an i deal $\mathrm{t}$ arget $\mathrm{f}$ or i maging an $\mathrm{d}$ therapy. Two cl inically approved therapeutic a ntibodies, trastuzumab and pe rtuzumab, are $\mathrm{u}$ sed $\mathrm{t} \mathrm{o} t$ reat $\mathrm{b}$ reast can cers $\mathrm{w}$ ith E RBB2 over-expression $[13,14]$. W hile bot $\mathrm{h}$ therapies $h$ ave $i$ ncreased disease $f$ ree survival $r$ ates of pa tients $w$ ith E RBB2 ove $r$ expressing b reast cancer by $5 \mathrm{~m}$ onths, $\mathrm{r}$ esistance to the exapy is common [15]. Currently, breast can cers are screened for potential treatment with an ti-ERBB2 therapy 
by biopsy. Biopsies may not be ideal due to pa tient pain and use of ex vivo detection, which $\mathrm{m}$ ay not be ph ysiologically relevant following r emoval from the patient [16]. A non-invasive i maging a gent, $s$ uch as a $r$ adiolabeled pe ptide, $w$ ould pr ovide $r$ eal-time detection of E RBB2, and e nsure $t$ hat $t$ he a ntigen i s bi ologically a ccessible $t$ o $t$ he therapeutic.

Previously, a 6 amino acid peptide (KCCYSL) was s elected by in vitro phage display for ERBB2 extracellular domain binding, and was consequently demonstrated to image ERBB2 expressing tumors in mice $[8,17]$. While tumor uptake was sufficient for SPECT i maging, non-target or gan uptake pos ed potential problems for further s tudies. The biodistribution indicated the peptide would be better suited for clinical applications with a decreased non-target organ uptake. Here, it was hypothesized that a microlibrary displaying the KCCYSL peptide flanked by random amino acids at both the $\mathrm{N}$ - and $\mathrm{C}$ termini c ould be us ed to s elect a pe ptide with improved in vivo tumor ta rgeting a nd pharmacokinetics. $\mathrm{T}$ his pr ocess, $\mathrm{t}$ ermed affinity $\mathrm{m}$ aturation, $\mathrm{i} \mathrm{s}$ a nalogous $\mathrm{t}$ o $\mathrm{t}$ he development of hi gh affinity antibodies b y the i mmune s ystem. The KC CYSL microlibrary was us ed for in vivo selections in mice bearing ERBB2-expressing MD AMB-435 hum an br east $\mathrm{x}$ enografts. S elected phages a nd $\mathrm{c}$ orresponding $\mathrm{s}$ ynthesized peptides were evaluated for ERBB2 and $\mathrm{c}$ ancer cell $\mathrm{b}$ inding affinity and specificity in vitro. Two target specific peptides were DOTA-conjugated and ${ }^{111}$ In-labeled for in vivo biodistribution and SPECT imaging analyses for comparison with previously published ${ }^{111}$ In-DOTA-KCCYSL. 
Phage cell bi nding a ssays $r$ evealed 9 pha ges with hi gher br east $\mathrm{c}$ arcinoma to breast e pithelial $\mathrm{c}$ ell bi nding $\mathrm{r}$ atios $(>1.56) \mathrm{t}$ han $\mathrm{K}$ CCYSL pha ge. $\mathrm{T}$ wo $\mathrm{s}$ ynthesized

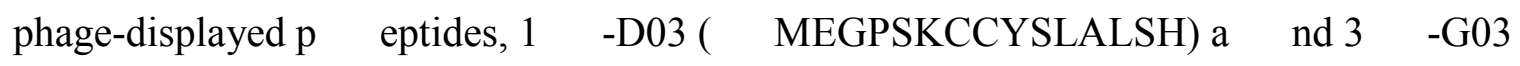
(SGTKSKCCYSLRRSS), d emonstrated affinities of $236 \mathrm{nM}$ and $289 \mathrm{n} \mathrm{M}$, respectively for recombinant ERBB2, compared to $351 \mathrm{nM}$ for KCCYSL. The corresponding SPECT probes, ${ }^{111}$ In-DOTA-1-D03 and ${ }^{111}$ In-DOTA-3-G03 bound w ith higher affinity to target cancer cells than KCCYSL. ${ }^{111}$ In-DOTA-1-D03 also demonstrated higher specificity for MDA-MB-435 c ells than ${ }^{111}$ In-DOTA-KCCYSL; h owever ${ }^{111}$ In-DOTA-3-G03 di d not retain its s pecificity. Thus, ${ }^{111}$ In-DOTA-1-D03 $\mathrm{w}$ as $\mathrm{c}$ hosen $\mathrm{f}$ or in vivo studies. Biodistribution a nalysis revealed tumor upt ake of $0.661 \% \mathrm{ID} / \mathrm{g}$ at $1 \mathrm{~h}$ po st-injection for ${ }^{111}$ In-DOTA-1-D03, s lightly 1 ess than ${ }^{111}$ In-DOTA-KCCYSL, which had a $0.78 \%$ ID/g uptake [17]. A s light diminishment o f tu mor u ptake w as a ccompanied b y greater reduction in non-target accu mulation, as ${ }^{111}$ In-DOTA-1-D03 di splayed higher tumor to organ $\mathrm{r}$ atios $f$ or the he art ( 5.11 ve rsus 3.54$), 1$ ung ( $1.64 \mathrm{v}$ ersus 0.95$)$, muscle ( 13.62 versus 8.67), bone (7.6 versus 3.9 ) and brain (39 versus 26 ) than ${ }^{111}$ In-DOTA-KCCYSL. At $2 \mathrm{~h}$ pos t-injection, the $\mathrm{r}$ apid bl ood c learance of ${ }^{111}$ In-DOTA-1-D03 1 ed to a hi gher tumor to blood ratio of 6.02:1 in comparison to $5.08: 1$ for ${ }^{111}$ In-DOTA-KCCYSL. Kidney retention of 1 -D03 was $4.75 \% \mathrm{ID} / \mathrm{g}$, a nearly 20 percent improvement over ${ }^{111} \mathrm{In}$-DOTAKCCYSL ( $5.75 \%$ ID/g) [17]. S PECT i maging revealed tumor-specific u ptake of ${ }^{111} \mathrm{In}$ DOTA-1-D03, which w as confirmed by blocking with unlabeled 1 -D03 peptide. These results $d$ emonstrate affinity $m$ aturation $f$ or en hanced $p$ harmacokinetics of a $t$ argeted peptide can be accomplished by in vivo phage display. The combination of E RBB2xviii 
specific $\mathrm{b}$ inding, rapid clearance an $\mathrm{d} t$ umor $\mathrm{s}$ pecificity $\mathrm{m}$ ay $\mathrm{m}$ ake 1 -D03 a vi able candidate for clinical imaging studies.

While it was successfully demonstrated that in vivo phage display can be used to improve the pharmacokinetics of a targeted peptide, selections can also be used to screen for pe ptides $w$ hich $\mathrm{m}$ imic na tural lig ands. $\mathrm{P}$ hage $\mathrm{d}$ isplay $\mathrm{h}$ as $\mathrm{b}$ een $\mathrm{u}$ tilized to $\mathrm{s}$ elect peptides which mimic natural binding sequences, such as the integrin binding sequence RGD, and in vivo phage display has been verified to select tumor-avid phages, allowing for both techniques to be combined to screen for tumor-associated peptide mimetics [7, $18,19]$. Currently, ex vivo high throughput screening techniques are employed to identify genes, $\mathrm{m}$ RNA a nd pr oteins t hat a re a berrantly e xpressed i $\mathrm{t}$ umor vasculature. $\mathrm{O}$ ne drawback of $\mathrm{s}$ uch $\mathrm{t}$ echniques i s the lack of f unctional in vivo data that they $\mathrm{p}$ rovide. While the p rimary focus of the in vivo KCCYSL mic rolibrary s election $\mathrm{w}$ as a ffinity maturation, a s econdary g oal $\mathrm{w}$ as to $\mathrm{s}$ creen for pe ptides $\mathrm{w}$ hich $\mathrm{m}$ imic na tural 1 igands associated $\mathrm{w}$ ith $\mathrm{t}$ umorigenesis. A $\mathrm{n}$ in vivo selection $\mathrm{f}$ or pha ge $\mathrm{w}$ hich $\mathrm{t}$ argeted hum an breast cancer xenografts was hypothesized to identify peptides with homology to cancerrelated proteins for in vivo imaging of breast cancer. For this, the recovered sequences of the K CCYSL mic rolibrary in vivo selection $\mathrm{w}$ ere $\mathrm{s}$ creened $\mathrm{f}$ or hom ology $\mathrm{t}$ o know $\mathrm{n}$ proteins, and one pe ptide, $3-\mathrm{G} 03$, shared significant hom ology with a secreted protein termed E GFL6 [20]. Egfl6 mRNA is u pregulated in s everal transcriptomic an alyses of human cancer biopsies, and the protein may play a role in tumor vascularization [21-23]. A c rucial s tep in tu morigenesis is the r ecruitment of nove 1 va sculature t o the site of 
neoplasia [24]. An i maging agent which could detect sites of n eovascularization w ould greatly enhance discovery, understanding and treatment of tumorigenesis.

While E GFL6 ha s be en i dentified i $\mathrm{n} t$ ranscriptomic a nalyses, $\mathrm{i}$ ts pr otein expression in b reast can cer had n ot b een analyzed. In o rder to further $\mathrm{c}$ haracterize the role of the put ative t umor va sculature protein E GFL6 in MDA-MB-435 hum an br east cancer, $\mathrm{m}$ RNA a nd pr otein e xpression $\mathrm{w}$ as a nalyzed. Egfl6 mRNA ex pression w as demonstrated in MDA-MB-435 c ells and E GFL6 w as s ecreted from these cel ls, which was expected based on the predicted sequence and structure of the protein. Due to the homology of 3-G03 to EGFL6, an EGFL6 peptide was synthesized and shown to target MDA-MB-435 c ells. EGFL6 peptide was conjugated to DOTA, radiolabeled with ${ }^{111}$ In and a nalyzed $\mathrm{f}$ or bi odistribution a nd $\mathrm{t}$ umor i maging $\mathrm{c}$ apabilities. S PECT i maging revealed upt ake of $t$ he pe ptide in a $\mathrm{m}$ anner $\mathrm{c}$ onsistent $\mathrm{w}$ ith o ther $\mathrm{t}$ umor va sculature targeting agents $[25,26]$. These results demonstrated that in vivo phage display provides a method for identifying potential peptide mimetics of tumor-associated proteins. Using in vivo phage display, a peptide with homology to EGFL6 was identified and successfully imaged t umor va sculature, i ndicating a role of EGFL6 in $t$ umor va scularization. The EGFL6 peptide and full length protein should be investigated further for potential uses in detecting and preventing tumor vascularization.

The in vivo selection that identified both an improved ERBB2 targeting peptide and a novel EGFL6 peptide mimetic yielded important imaging peptides, however using these type of peptides for ERBB2 imaging and therapy can have limited utility. One of the major o bstacles to s uccessful t reatment is the o ccurrence of $r$ esistance to $t$ argeted 
therapies. Development of a peptide which can detect resistance-susceptible breast cancer prior to treatment would greatly aid in treatment of these malignancies. BT-474 hum an breast $\mathrm{c}$ ancer $\mathrm{c}$ ells ove rexpress $\mathrm{E}$ RBB2, i n addition $\mathrm{t} \mathrm{o}$ a nother $\mathrm{r}$ esistance s usceptible target, the estrogen receptor. This cell line has been demonstrated to develop resistance to both $\mathrm{t}$ rastuzumab, w hich $\mathrm{t}$ argets $\mathrm{E} \mathrm{RBB} 2$, and tamoxifen, w hich $\mathrm{t}$ argets $\mathrm{t}$ he e strogen receptor $[27,28]$. A peptide which targets BT- 474 human breast tumors may serve as a potential detection agent for therapy resistant breast cancer. Thus, it was proposed that an in vivo selection for tumor-avid phage in mice bearing BT-474 xenografts would identify targeted peptides for the resistance-susceptible breast cancer cell line.

A phage library displaying random 15 amino acids from the tip of coat protein III was us ed for four rounds of in vivo selection in B T-474 x enografted mice. Following selection, 14 pha ges $w$ ere $i$ dentified $f$ or cell $b$ inding as says $d$ ue $t$ o $t$ he $p$ resence of multiple copies of the full length or partial sequence in the output of the selection, as this is often an indicator of a successfully s elected phage. One phage, clone 51 , had va stly superior B T-474 hum an br east c ancer bi nding, and w as s ynthesized for a nalysis a s a peptide. The peptide, 51 (ATWLPVPVVFMASA), bound BT-474 cells specifically with an $\mathrm{EC}_{50}=2.33 \mu \mathrm{M}$, an affinity previously demonstrated to allow for tumor imaging in vivo [29]. Peptide 51 was therefore radiolabeled with ${ }^{111}$ In, its retained affinity confirmed in vitro and examined for biodistribution and SPECT imaging in BT-474 tumor-bearing mice. While tumor uptake was moderate at $0.11 \% \mathrm{ID} / \mathrm{g}$, SPECT imaging revealed that the peptide was highly concentrated in the area surrounding the tumor, in a similar manner to vasculature targeted RGD peptides and anti-VEGF antibodies [25, 26]. Since vasculature $\mathrm{xxi}$ 
binding can $b$ e m ediated by as few as three a mino aci ds an $d$ phage $d$ isplay ha $\mathrm{s}$ be en previously be en e stablished $t$ o $t$ arget $t$ umor va sculature, know $n$ va sculature $t$ argeting peptides reported in the literature were further examined for partial sequence identity to peptide 51 .

It was discovered that the $\mathrm{N}$-terminal 5 amino acids of 51 were identical to the $\mathrm{N}$ terminal 5 a mino a cids of a $\mathrm{p}$ eptide, $\mathrm{V} 1$ ( $\underline{\text { ATWLPPR }})$, s hown $\mathrm{t}$ o bi nd $\mathrm{t}$ he $\mathrm{t}$ umor vasculature receptor Nrp1 [30]. Nrp1 is expressed in both tumor vasculature and BT-474 cells [31], therefore it was a possible target of peptide 51. S urprisingly, only full length 51 bound bot h B T-474 and H UVEC e ndothelial c ells, w hile V 1 onl y b ound H UVEC cells. Additionally, comparison of the in vivo properties of peptide 51 and V 1 revealed that the peptides exhibited different biodistributions and V $1 \mathrm{w}$ as unable to differentiate tumor tissue by SPECT imaging [32]. The results suggested peptide $51 \mathrm{~b}$ inding was not mediated $\mathrm{b}$ y $\mathrm{i}$ ts $\mathrm{s}$ hared s equence $\mathrm{w}$ ith $\mathrm{V} 1$. $\mathrm{T}$ his $\mathrm{w}$ as $\mathrm{c}$ onsistent $\mathrm{w}$ ith pr evious characterization of the V1 peptide, which de termined that the critical binding sequence was the C-terminal LPPR [33]. Finally, it was determined that neither an $\mathrm{N}$-terminal nor C-terminal truncated form of peptide $51 \mathrm{c}$ ould bind to BT- $474 \mathrm{cells}$ with the same high affinity and specificity of the full length peptide. These results indicate that peptide 51 is a $n$ ovel $t$ umor i maging ag ent, cap able of i maging $r$ esistance s usceptible b reast $\mathrm{c}$ ancer xenografts in mice.

The work presented in this dissertation provides evidence of the utility of phage display for the discovery of novel breast cancer targeted peptides. Phage display can be used $t$ os elect $s$ econd ge neration pe ptides with i mproved pha rmacokinetics, a $s$ xxii 
demonstrated with peptide 1-D03 [19]. Additionally, in vivo selection allows for a highthroughput s creening of pe ptides w hich $\mathrm{m}$ ay mimic na tural 1 igands. Discovery o fa peptide hom ologous to EGFL6 and subsequent confirmation of EGFL6 expression and tumor vasculature targeting of the peptide has provided the foundation for future studies examining the role of E GFL6 in t umor va scularization a nd the a bility of the E GFL6 peptide t o de tect ne ovascularization. Lastly, pha ge di splay can be us ed to a ddress a disease phenotype, such as therapy resistant breast cancer. In vivo phage display selected a peptide which was able to bind BT-474 cells with good affinity in vitro and specifically target and image BT-474 human breast cancer xenografts in vivo. Development of three targeting peptides, while significant, is only a small fraction of what can be accomplished by phage display. 
CHAPTER 1

\section{INTRODUCTION}




\section{Preface}

From a ncient E gyptian surgery s crolls, t hrough $\mathrm{H}$ ippocrates, t o P aul E hrlich's "magic bullet", science has attempted to elucidate, describe, and eliminate c ancer. With more than $1.5 \mathrm{~m}$ illion cases of can cer diagnosed each year, the prevalence of $\mathrm{c}$ ancer is one of s ociety's gr eatest bur dens (1). $\mathrm{O}$ ne of th e $\mathrm{k}$ eys to e liminating the $\mathrm{d}$ isease is through a thorough und erstanding of its induction and progression. A s knowledge has progressed, cancers of various organs have been disseminated. Carcinomas of the breast, in particular, are one of the most common cancers a mong women, owing to the uni que biology of the or gan (2). Understanding the transformation from h ealthy to ma lignant tissue and the identifiable markers that accompany this transformation have allowed for more $\mathrm{p}$ recise $\mathrm{i}$ dentification an $\mathrm{d} t$ reatment of can cer. Incremental $\mathrm{s}$ teps $\mathrm{h}$ ave i mproved detection an d subsequently treatment, e nhancing outcome. S urgical removal, non invasive imaging, radiation, chemotherapeutics and targeted therapy have each advanced quality of care (3). It is the combination of these established techniques, along with the incorporation of a $\mathrm{n}$ ew $\mathrm{w}$ ave of $\mathrm{i}$ maging and $\mathrm{t}$ herapeutic $\mathrm{t}$ ools $\mathrm{t}$ hat will pus $\mathrm{h} t$ he boundaries of cancer treatment. 


\section{Cancer}

Cancer occurs as a progression of a cell with a defined paradigm for replication and a poptosis to a n un mitigated m ultiplying of a select gr oup of cells, which lack the controlled growth, programmed death, or a combination of both, present in surrounding tissues. The ex ternal causes of cancer, which include but a re not limited to chemicals, radiation, and viral infection, introduce a mutation in the cell's genetic code. Chemical and radiation induced genetic damage is random, and accumulates throughout the lifetime of an individual (4). Although single mutations may be phenotypically silent, a series of mutations may cause abnormal function of a gene or set of genes. The mutation of a gene that is critical to the regulation of cell division, growth or death can be the trigger point for carcinogenesis (5). Viral infection, on the other hand, can introduce a malignant gene to a normal cell, inducing cancer (6). Human papillomavirus, which has been detected in $99.7 \%$ of c ervical cancers, produces two onc oproteins, E 6 and E 7 which stimulate c ell growth a nd e liminate g rowth-related co ntrols (7). Viral-mediated production of these proteins is enough to drive cancer initiation. Whether the infection or mutation leads to an over-expression of a factor causing cell growth, or the loss of a control point inhibiting it, the end result is a population of cells multiplying outside of the normal developmental controls. In order to detect and eliminate cancer, it is important to identify the inherited phenotypic changes that lead to cancer initiation and progression.

Maintenance of a population of cells is an ongoing balance of replication and cell

death. Older cells are systematically destroyed, in a process known as apoptosis, while 
new cel ls a re created $t$ or eplace $t$ hem (8). I $\mathrm{n}$ a ddition to maintenance, $\mathrm{t}$ issues $\mathrm{m}$ ust respond to biological changes such as puberty, pregnancy or injury. A complex network of $\mathrm{r}$ eceptors act ivated and $\mathrm{r}$ epressed by $\mathrm{l}$ ocal a nd s ystematic $\mathrm{l}$ igands a cts as a car eful coordinator of normal physiological processes. Tumorigenesis occurs when one or more of the processes no 1 onger functions as it $\mathrm{w}$ as intended. One of the methods of $\mathrm{c}$ ancer formation is through the 1 oss of a poptosis. Proteins s uch a s p53, w hich regulates the production of proteins that are involved in a number of cellular viability c heckpoints, may be al tered or completely absent, resulting in an inability to produce controlled cell death (9). Growth $\mathrm{f}$ actors, $\mathrm{w}$ hich $\mathrm{t}$ ypically $\mathrm{f}$ unction dur ing de velopment a nd $\mathrm{w}$ ound repair, can be equally c arcinogenic if u ncontrolled. For ex ample, over-expression of a ligand such as ep idermal growth fa ctor (E GF), or i ts r eceptor EGFR, often results in malignancy (10). Over-expression of gr owth factors 1 eads to constitutive $m$ itogenesis, however this is only the first step in the progression of cancer. In addition to mitogenic signaling, continuous uncontrolled growth can only be sustained after the tumor reaches 1-2 $\mathrm{mm}$ in diameter through angiogenesis (11). As a group of tumor cells proliferate, the existing va sculature is no 1 onger s ufficient t o support ne $\mathrm{w}$ growth (12). In or der to continue to proliferate, the cells must release factors which promote growth of new blood vessels, creating a new supply line of nutrients for further growth (13). However, rapid and di sordered growth of a tumor a ffects the p rocess of va scularization, w ith the end result being a disorganized and permeable set of blood vessels (14). Uncontrolled growth, improper va sculature a nd a poor 1 ymphatic s ystem ul timately c ontribute t o a $t$ umor environment th at is $\mathrm{h}$ ypoxic, a cidic a nd $\mathrm{p}$ artially necrotic. In th is ma nner th e tu mor 
progresses until it me ets the $\mathrm{b}$ asement me mbrane, where it encounters a ne w level of resistance.

As the tumor grows to approach the basement membrane, it must pass through the extracellular ma trix a nd in to the s troma, in a process know $\mathrm{n}$ a s i nvasion (15). A fter invasion, it is has been demonstrated that only select subpopulations of cells will have the ability to circumvent the host immune system, implant in a secondary tissue, invade and establish a new tumor microenvironment (16). In fact, for most cancer patients, it is the progression of m etastatic le sions that will u ltimately lead to d eath (17). Elucidation of metastatic properties of these subpopulations is, therefore, an intense focus of research. The "seed and soil" hypothesis, first postulated by Stephen Paget in 1889, states a tumor cell may implant in a tissue based on the characteristics of its tissue of origin (the seed) and its destination tissue (the soil) (18). Evidence to support the hypothesis has continued to collect, and it is generally regarded today that the tissue of origin is an important factor in a ssessing tr eatment o ptions (19). Although t here is c ertainly ove rlap i n $m$ alignant development mechanisms, it is important to place emphasis on a specific tissue, due to shared characteristics of tissue-related cells among individual cancers. The scope of this dissertation focuses on b reast cancer and proteins, such as ERBB2 and EGFL6, defined in the proceeding chapters, which contribute to the growth and metastasis of the disease. 


\section{Breast Cancer}

Breast cancer is the number one cause of cancer among women, and the second leading cause of cancer-related death. Although it is not known why breast tissue is most susceptible to malignant transformation, its extensive use of growth factors and hormones is thought to be a possible link to increased cancer risk (20). Approximately one in eight women will develop breast cancer in her lifetime, one in 25 before age 60, and one in 200 before they are 40 . The relatively high probability of developing breast cancer before the age of 60 is co mpounded $b$ y the fact $t$ hat $b$ reast can cer i s t he $\mathrm{m}$ ost $d$ eadly fo $\mathrm{rm}$ of carcinoma in w omen of this a ge group (1). T he hi gh m ortality could be due t o the increased probability of aggressive, invasive tumors in young women (21). To understand the increased risks of cancer development and progression, it is important to examine the known bi ological functions of the br east and the conditions which facilitate malignant development.

Although br east t issue f ormation i nitially o ccurs dur ing f etal de velopment, the tissues unde rgo s everal pos tnatal c hanges. Remodeling of br east t issue during pube rty and a gain following pregnancy are elicited by growth hor mones, such as estrogen, and their c orresponding receptors (2). Deregulated es trogen s ignaling has 1 ong be en implicated i $\mathrm{n}$ c ancer $\mathrm{p}$ rogression, a nd clinically approved therapies that a ntagonize estrogen $\mathrm{f}$ unction, $\mathrm{s}$ uch a s t amoxifen, c an s uppress e strogen dr iven c ancers (22). However, the presence of es trogen receptors in the breast cannot solely account for the increased f requency of breast cancer d evelopment, as estrogen act s i n a s ystematic 
manner and plays a role in the development of several reproductive and non-reproductive tissues besides the breast. In addition to estrogen related transformation, the EGFR family of receptors (ERBB) has been shown to play a critical role in mammary maturation (23). The role of the ERBB proteins in development has been studied through tissue specific knockouts in de veloping m ouse $m$ ammary glands. Loss of a ny of the E RBB $f$ amily members results in in complete ma mmary development, ranging from incomplete ductal growth to impaired lactation (24). Like the e strogen receptor, improper signaling of the ERBB family is also a driver of br east cancer. Although $m$ alignant $t$ ransformation of breast tissue is a complex series of events undoubtedly involving many proteins, evidence has supported a major role of both the estrogen receptor and the epidermal growth factor receptors in breast can cer $(2,25)$. In fact, therapies targeting the estrogen receptor and ERBB family $\mathrm{m}$ ember, ERBB2, $\mathrm{h}$ ave both be en $\mathrm{s}$ uccessful as targeted $\mathrm{b}$ reast $\mathrm{c}$ ancer treatments $(22,26)$. It is clear that understanding the biological functions that drive breast tissue growth $\mathrm{h}$ as pr oven va luable i $\mathrm{n} 1$ ater $\mathrm{i}$ dentifying $\mathrm{t}$ he pos sible $\mathrm{m}$ echanisms of carcinogenesis. Additionally, de tection of a berrant expression of receptors found solely or in higher amounts on the surface of cancer cells can be used to characterize and direct a course of treatment for individualized breast cancers. 


\section{Breast Cancer Detection}

Knowledge of the biological development of breast cancer can be used to advance detection capabilities. Early detection is paramount in breast cancer treatment, as survival drops precipitously following progression of the disease (27). Current detection methods are largely based on breast exams and mammography. Both methods of detection provide a means to non-invasively detect tumors ba sed on a bnormal masses of c ells. Although both $\mathrm{m}$ ethods a re $\mathrm{v}$ aluable tools, they $\mathrm{h}$ ave at least tw o limita tions. The first is both technologies are biased towards the detection of slower growing, less aggressive tumors. The bias originates from the need for a significant mass of tumor cells for diagnosis. The window of opportunity for detection is much longer for a slow growing mass, whereas aggressive $t$ umors $m$ ay be $u$ ndetectable at $t$ he $t$ ime of $s$ creening, but p rogress $t$ o a $n$ advanced stage before a subsequent test. Therefore mammograms and breast ex ams are excellent detection methods, but will do little to detect the most dangerous malignancies at an e arly s tage. In addition $\mathrm{t} o \mathrm{a} n \mathrm{i}$ nherent growth $\mathrm{r}$ ate $\mathrm{b}$ ias, $\mathrm{t}$ he e ffectiveness of mammography and breast exams is diminished in younger or denser breast tissue (28). Unfortunately, the s ubpopulation of $\mathrm{w}$ omen $\mathrm{w}$ ho a re $\mathrm{m}$ ost pr one $\mathrm{t} \mathrm{o}$ aggressive $\mathrm{t}$ umor growth is a lso younger w omen o $\mathrm{r} w$ omen $\mathrm{w}$ ith de nse br east $\mathrm{t}$ issue (1). T he $\mathrm{s}$ econd detriment of breast exams and mammograms is that they do not provide any information about the biochemical nature of the tumors. The expression pattern of specific proteins, or biomarkers, is crucial to determining susceptibility to different therapeutic approaches. Current $\mathrm{m}$ ethodologies $\mathrm{s}$ imply $\mathrm{i}$ dentify $\mathrm{t}$ he presence of a $\mathrm{m}$ ass, $\mathrm{w}$ hich $\mathrm{m}$ ust $\mathrm{b}$ e 
characterized by other as says. While breast ex ams and mammograms are valuable tools in br east $\mathrm{c}$ ancer di agnosis, i dentification a nd de tection of cancer s pecific p roteins can serve to simultaneously $\mathrm{d}$ etect and $\mathrm{c}$ haracterize a ggressive $\mathrm{m}$ alignancies, at an earlier point than traditional methods.

In ad dition t o d etection b y physical ch aracteristics, $\mathrm{b}$ iochemical $\mathrm{d}$ iagnosis can also be a chieved. A w idespread non -invasive $\mathrm{c}$ ancer ima ging te chnique is the us e of ${ }^{18}$ fluorine $\left({ }^{18} \mathrm{~F}\right)$-labeled deoxyglucose (FDG). It is thought that the enhanced growth and, by necessity, m etabolism of can cer cel ls promotes en hanced uptake of the radiolabeled glucose a nalog us ed to diagnose many carcinomas (29). Unable to be broken down or released due to its altered chemical structure, the imaging agent collects in tissues of high glucose metabolism, e.g. tumor and brain. Concentration of FDG permits identification of small tumors and metastases through detection of a positron emitted during the decay of radioactive ${ }^{18} \mathrm{~F}$. The success of high resolution imaging provided by FDG-guided positron emission to mography (PET) has led to many more attempts to identify cancer based on concentration of an i maging a gent through d elivery facilitated by differences b etween cancer cells and their surrounding normal tissues (30-32). However not all cancers have increased F DG upt ake. An a dditional m ethod of de tecting $\mathrm{c}$ ancer $\mathrm{c}$ ells is through the differential e xpression of proteins a nd ot her m olecules a ssociated $w$ ith the bi ological processes $\mathrm{n}$ ecessary for $\mathrm{t}$ umor de velopment. $\mathrm{T}$ hese $\mathrm{c}$ ancer-related $\mathrm{m}$ olecules, $\mathrm{t}$ ermed biomarkers, provide a target for a $\mathrm{i}$ maging a gent. D etection of bi omarkers in cancer provides a twofold advantage. Not only are cancers detected at early stages and possibly before current methods of detection, but a key biological property is identified. 


\section{ERBB2}

In order to accomplish biomarker characterization, proteins must be identified that play a significant role in m alignant transformation, while be ing a bsent or expressed at lower levels in surrounding tissue. In the breast, the ERBB family of tyrosine kinases is essential for normal development (23). Deregulation of the receptors, however, has been implicated i $\mathrm{n} t$ he $\mathrm{d}$ evelopment o $\mathrm{fb}$ reast can cer (33). T he $\mathrm{f}$ amily consists of four members: E GFR (HER1), E RBB2 (HER2/neu), ERBB3 (HER3) and ERBB4 (HER4). The structure of each receptor includes an extracellular ligand binding domain, a single pass transmembrane domain, and an intracellular tyrosine kinase domain. Interactions in the e xtracellular dom ain dr ive $\mathrm{s}$ ignaling $\mathrm{t}$ hrough hom $\mathrm{o}-$ and he terodimerization $\mathrm{w}$ ith another EGFR family receptor (34). A typical EGFR receptor, in the absence of ligand, remains in a folded, closed state with a ligand binding portion of the extracellular domain exposed. Ligand binding by the receptor induces a conformational change in the external domain, e xposing a di merization arm $\mathrm{t}$ hat i s buried in $\mathrm{t}$ he non -liganded state. $\mathrm{T}$ wo receptors in the active conformation $\mathrm{c}$ an a djoin via in teractions between dimerization arms, unlocking the potential for tyrosine kinase activity within the intracellular domain. Unlike the extracellular domain, intracellular domain dimerization is asymmetrical. After dimerization, the $\mathrm{C}$-terminal tail of one receptor ex poses an A TP binding pocket on its partner receptor. Bound ATP catalyzes transphosphorylation of specific tyrosine residues, with phos phorylation patterns dependant on a ctivating ligands. P hosphorylated tyrosine residues s erve a s doc king poi nts $f$ or a daptor proteins used $t o$ i nitiate dow nstream 
signaling. Through various combinations of ligand and receptor expression, cells are able to facilitate a vast array of responses using the ERBB signaling pathways.

Although canonical ERBB family signaling pathways require a ligand, ERBB2 is unique $\mathrm{w}$ ithin $\mathrm{t}$ he $\mathrm{f}$ amily because $\mathrm{i}$ tha $\mathrm{s}$ no $\mathrm{k}$ nown 1 igand. $\mathrm{C}$ rystallographic $\mathrm{s}$ tudies indicate that this is most likely due to the fact that it $r$ emains fixed in the open, active state $\mathrm{w}$ ith its dimerization d omain ( domain II) exposed (35). D ue to its c onstitutive openness to dimerization, the receptor is the primary binding partner for all of the EGFR family (36). Additionally, di mers containing ERBB2 haves everal o ncogenic characteristics. Each pair remains at the cell surface longer than non-ERBB2 containing dimers, a llowing $\mathrm{f}$ or i ncreased s ignaling. $\mathrm{E}$ ven a fter e ndocytosis of a $\mathrm{n}$ ERBB2 heterodimer, the receptors are more likely to be recycled to the cell surface to continue signaling. In addition, the binding partner of ERBB2 retains its ligand longer than a dimer with no ERBB2. The enhanced formation, $s$ tability a nd s ignaling pot ency of E RBB2 dimers has made targeting the receptor an effective method of controlling breast cancers that overexpress ERBB2.

Two humanized, monoclonal antibodies, trastuzumab and pertuzumab, have been approved by the Food and D rug A dministration for the $t$ reatment of E RBB2-positive breast cancers $(26,37)$. Trastuzumab binds to a portion of ERBB2 near the cell wall, and it i s thought t $\mathrm{o}$ a ct t hrough a c ombination of steric hi ndrance and a ntibody-directed cellular c ytotoxicity (35). P ertuzumab bi nds E RBB2 i $\mathrm{n}$ i ts di merization dom ain, effectively inhibiting dimerization with other family members (38). Both receptors have altered t he pr ognosis of E RBB2-positive $b$ reast can cer, s ignificantly i ncreasing $t$ he disease free s urvival rates of $\mathrm{w}$ omen $\mathrm{w}$ ith these $\mathrm{m}$ alignancies. $\mathrm{C}$ urrently, de tection of 
ERBB2 in breast cancer is performed by immunohistochemistry and in situ hybridization, which require biopsies. Examining a tissue by biopsy is not ideal because the procedure can be painful for patients, and removing tissue from a person may alter the molecular expression patterns of cells (39). A non-invasive ERBB2 imaging agent would therefore alleviate $\mathrm{t}$ he ne ed $\mathrm{f}$ or biopsies, $\mathrm{w}$ hile $\mathrm{s}$ imultaneously de tecting $\mathrm{w}$ hether E RBB2 i s accessible from the blood stream, the delivery route of both trastuzumab and pertuzumab. Owing $t$ o $t$ he ne ed $f$ or nove $1 \mathrm{i}$ maging ve ctors, $t$ arget-specific $m$ olecules $h$ ave $b$ een developed by num erous methods, how ever on e of the most widely us ed and successful strategies is the use of bacteriophage (phage) display. 


\section{Phage Display}

Phage display is a combinatorial technology pioneered by Dr. George P. Smith in 1985 a $t \mathrm{t}$ he $\mathrm{U}$ niversity of $\mathrm{M}$ issouri (40). $\mathrm{T}$ he $\mathrm{t}$ echnology $\mathrm{w}$ as $\mathrm{d}$ eveloped using filamentous phage, a long rod shaped particle approximately $1 \mu \mathrm{m}$ in length and $30 \mathrm{~nm}$ in diameter. A p hage $\mathrm{p}$ article co nsists of s everal coat $\mathrm{p}$ roteins $\mathrm{t}$ hat en capsulate $\mathrm{s}$ inglestranded DNA encoding for production of the viral proteins. A phage is able to infect a host bacterial c ell, inject its genetic material, and generate many thousands of copies of itself. Phages are secreted out of the bacterial cell by assembly of coat proteins at the cell wall, insertion of the phage genome, and excretion. It was discovered that the outer coat proteins $\mathrm{c}$ ould $\mathrm{t}$ olerate $\mathrm{i}$ nsertion of $\mathrm{f}$ oreign peptides, a nd thus 1 ibraries of pha ge displaying random molecules could be generated by manipulating the phage genome with altered coat protein genes.

The structure of a phage is dictated by its genome. The body of the phage consists mainly of c oat protein VIII, which is present in $\sim 2700 \mathrm{c}$ opies a long the length of the phage. At each end of the phage are two pairs of proteins, at one tip coat proteins III and VI, and the other coat proteins VII and IX. The two most widely us ed coat proteins for phage display are coat protein VIII and III. Coat protein VIII is beneficial for displaying a targeted peptide because a phage can display $~ 100$ copies of an altered coat protein VIII in c ombination w ith native c oat protein V III. C oat protein III is onl y di splayed in 3-5 copies at the tip of the phage, how ever the protein is 1 ong (200 a mino acids) and can tolerate insertion of molecules as large as an antibody heavy chain. Coat protein III has 
been the primary site of foreign peptide display because of its flexibility, distance from the phage body, and low number of displayed foreign sequences allowing for selection of high af finity molecules. A p hage library can be created by ligating DNA en coding for random pe ptides into the coat protein III gene, and transfecting hos $t$ ba cteria $w$ ith the modified plasmids. The bacterial cells then produce thousands of each random sequence, creating a pool of phage displaying a highly diverse number of sequences.

A pha ge di splay s election ut ilizes $t$ he $t$ olerance of pha ge $t$ o f oreign peptide insertion, in addition to its self-replicating ability, to competitively isolate peptides for a desired function. A single phage library can contain up to $10^{9}$ unique peptide sequences present i $\mathrm{n}$ ap proximately 1000 copies each. $\mathrm{T}$ he en tire $\mathrm{p}$ hage $\mathrm{l}$ ibrary can $\mathrm{t}$ hen $\mathrm{b}$ e incubated $w$ ith a $t$ arget, a llowing s pecific pha ge to bi nd, a nd removing all unbound phage. The captured phage are then eluted and amplified by infection in bacteria, and the resulting purified phage pool is a subpopulation of phages with the capability of binding the desired target. This subpopulation of phage can then be subjected to another round of competitive s election, in w hich h igher a ffinity $\mathrm{p}$ eptides w ill o utcompete lower a ffinity peptides, e ffectively further e nriching $t$ he popu lation $w$ ith onl $y t$ he hi ghest affinity phages. A single phage library can be subjected to a number of rounds of selection, with careful co nsideration given $t$ o $t$ he $b$ alance $b$ etween s electing $t$ arget-avid pha ges a nd phages with a growth advantage, due to the iterative infections that are necessary with each round of selection, which lead to bias toward phage with more efficient propagation (41). P eptides s pecific for a given $\mathrm{f}$ unction $\mathrm{c}$ an $\mathrm{t}$ hen be de termined us ing $\mathrm{t}$ he genetic material of the pha ge for further refinement or characterization out side of the pha ge scaffolding. 
Isolation of peptides from phage display selections can be accomplished using a number of targets both in vitro and in vivo. In vitro, phage display has been utilized to select $\mathrm{p}$ eptides $\mathrm{t}$ hat $\mathrm{b}$ ind $\mathrm{t}$ ransmembrane $\mathrm{r}$ eceptors, glycoproteins, $\mathrm{i}$ ntegrins, carbohydrates, D NA, an d ev en m etals (42-46). The pe ptides a re hi ghly s pecific, a nd generally have moderate to high affinity for their target in the low $\mu \mathrm{M}$ to high $\mathrm{nM}$ range $(42,43)$. T he $t$ argeted $p$ eptides ha ve be en us ed in vivo, most relevantly to de tect and characterize human tumors in mice $(47,48)$. Recently, phage display technology has been translated to in vivo selections, in or der $\mathrm{t}$ o $\mathrm{c}$ apitalize on $\mathrm{t}$ he ph ysiologically a ccurate nature of target display an in vivo system presents. Selections have been accomplished in both $\mathrm{m}$ ice a nd hum ans, for $\mathrm{t}$ argets i ncluding $\mathrm{t}$ umors, $\mathrm{t}$ umor va sculature, a nd specific tissues $(49,50)$. T he s uccess of $t$ hese pe ptides de monstrates $t$ hat $t$ he 1 ibrary s ize, robustness, and r eplication a bility of pha ge di splay ha ve positioned this combinatorial technique at the forefront of targeted peptide discovery. 


\section{Peptides}

Typically, the initial choice for a targeting agent is a monoclonal antibody. The exquisite specificity and affinity of antibodies has made them a $\mathrm{h}$ ighly at tractive choice for mo lecular ta rgeting. $\mathrm{H}$ owever, a ntibodies ha ve ha $\mathrm{d} l$ imited s uccess $\mathrm{f}$ or $\mathrm{s}$ ome applications in vivo for s everal r easons. F irst, antibodies are large foreign o bjects, an d thus can el icit an immune response (51). Humanization of antibodies has lessened this response to s ome d egree, h owever clinical tr ials $\mathrm{w}$ ith a ntibodies $\mathrm{s}$ till $\mathrm{r}$ eport immu nerelated side effects (52). The large size of antibodies also poses an additional problem, in that their pharmacokinetics are of ten slow and result in high liver uptake. Additionally, the la rge mo lecular w eight of a ntibodies limit s t umor pe netration, s ince the i rregular vasculature o f a $\mathrm{t}$ umor pr events a ctive $\mathrm{t}$ ransport of bl ood-borne $\mathrm{m}$ olecules. Instead, diffusion is the main source of transport, and the size of an antibody limits its diffusion rate. Peptides, on the other hand, can overcome many of the obstacles encountered by the use of antibodies. A typical peptide has a molecular weight under $3 \mathrm{kD}$ a, approximately $50 \mathrm{t}$ imes s maller $\mathrm{t}$ han a $\mathrm{n}$ a ntibody. $\mathrm{T}$ he 1 ow $\mathrm{m}$ olecular $\mathrm{w}$ eight pr ovides $\mathrm{r}$ apid pharmacokinetics and unbound peptide is cleared from the bloodstream in under 1 hour (30). S ince di ffusion is inversely p roportional to m olecular w eight, a pe ptide a lso ha s superior $t$ umor pe netration. $\mathrm{P}$ eptides a re not $\mathrm{w}$ ithout dr awbacks, a nd the $\mathrm{t}$ rade-off fo $\mathrm{r}$ small size is typically a decreased affinity. The rapid pharmacokinetics also may result in the peptide be ing removed from the bloodstream too rapidly, de creasing overall t umor 
uptake. $\mathrm{D}$ espite $\mathrm{t}$ hese 1 imitations, pe ptides ha ve be en de monstrated to image hum an tumors in vivo, and thus are relevant for future targeting vectors.

Successful tumor imaging peptides can be derived from natural peptide ligands or combinatorial 1 ibraries. $\mathrm{P}$ eptides found in $\mathrm{N}$ ature that $\mathrm{b}$ ind to $\mathrm{r}$ eceptors $\mathrm{d}$ ifferentially expressed i $\mathrm{n} \mathrm{c}$ ancer $\mathrm{h}$ ave $\mathrm{h}$ ad $\mathrm{t}$ he $\mathrm{m}$ ost $\mathrm{s}$ uccess $\mathrm{cl}$ inically. T hese $\mathrm{p}$ eptides $\mathrm{i}$ nclude derivatives of somatostatin, gastrin releasing peptide, and $\alpha$-melanocyte s timulating hormone (53-55). The p eptides ha ve be en de monstrated to s uccessfully image t umors expressing their r eceptors in both $\mathrm{m}$ ice and hum ans. T argeted peptide di scovery is not limited to naturally occurring peptides. Combinatorial libraries, including phage peptide display libraries, can be selected to home to tumor targets. The only peptide applied thus far to bot h m ouse and human i maging is the a rg-gly-asp pe ptide, $\mathrm{t}$ ermed RGD (56). Although R GD i s a na tural i ntegrin bi nding s equence, pha ge di splay w as us ed t o elucidate $\mathrm{t}$ hat $\mathrm{t}$ he $\mathrm{p}$ eptide $\mathrm{w}$ as $\mathrm{m}$ ore $\mathrm{s}$ table an $\mathrm{d} \mathrm{h}$ ad $\mathrm{a} \mathrm{h}$ igher affinity i $\mathrm{n}$ a $\mathrm{c}$ ysteine constrained form (57). In a ddition to R GD, pha ge di splay has be en us ed to i dentify a number of peptides that successfully image tumors in mice. Peptides targeting ERBB2, galectin-3 and $\mathrm{pl}$ ectin, ha ve $\mathrm{b}$ een i solated $\mathrm{b} \mathrm{y}$ in vitro phage display, in a ddition $\mathrm{t} \mathrm{o}$ peptides targeting PC-3 prostate cancer, breast tumor vasculature, and a number of organs in vivo $(47-50,58)$. Ostensibly, any antigen can be targeted by phage-displayed peptides, providing a powerful tool for future applications in personalized medicine. 


\section{Radiolabeling}

Following the $\mathrm{d}$ evelopment of a ta rgeted $\mathrm{p}$ eptide, a $\mathrm{n}$ ima ging mo iety must be conjugated $t$ o t he pe ptide $t$ o a llow $f$ or $t$ racking of $t$ he pe ptide in vivo. $S$ everal considerations must be examined when choosing the type of radiolabeling system for a peptide, i ncluding c onjugation, $r$ adioactive $\mathrm{i}$ sotope, ha lf-life a nd t ype o f e mission. Conjugation of a radioactive molecule can be accomplished either directly or through the addition of a radiometal chelator. Direct conjugation is often accomplished using ${ }^{124 / 125} \mathrm{I}$, ${ }^{18} \mathrm{~F}$ and ${ }^{11} \mathrm{C}$. While di rect $\mathrm{c}$ onjugation $\mathrm{w}$ ith $\mathrm{r}$ adioactive fluorine or $\mathrm{c}$ arbon produces a stable, radiolabeled peptide, the chemistry is often complex, and the half-life of ${ }^{18} \mathrm{~F}(110$ $\min )$ and ${ }^{11} \mathrm{C}(20 \mathrm{~min})$ require large quantities of radioactivity to complete the synthesis. Iodine of fers a s impler radiolabeling p rocedure, however the 1 abel c an b e m ore 1 abile, resulting in dissociation from the targeted vector. The addition of a radiometal chelator allows for c onjugation of unl abeled chelator followed b y radiolabeling, a llowing for a simpler and more rapid approach to radiolabeling.

The $\mathrm{c}$ hoice of $\mathrm{c}$ helator dictates $\mathrm{t}$ he s tability of the $\mathrm{r}$ adiolabel a nd opt ions for radiometal. Chelators ma y be acyclic, such as (DTPA) and 6-hydrazinonicatonic acid (HYNIC), or c yclic, i ncluding 1,4,7,10 -tetraazacyclododecane-1,4,7,10-tetraacetic aci d (DOTA), 1,4,7-triazacyclononane-triacetic aci $\quad \mathrm{d}(\quad$ NOTA $), \quad 1,4,8,11-$ tetraazacyclotetradecane-1,4,8,11-tetraacetic acid (TETA) and (CB-TE2A) (48, 59-62). Although a cyclic chelators of fer $\mathrm{r}$ apid a nd 1 abile 1 abeling $\mathrm{c}$ onditions, th eir s tability is often not suitable for in vivo use (63). Cyclic chelators are ideal for peptides because they 
provide stable chelation, are able to bind a wide variety of radiometals, and their harsher labeling chemistry usually does not alter the properties of the peptide.

Often chelators may bind several radiometals, requiring on e specific label to be chosen. The choice of a radiometal is based on the type of emission and half-life desired. Single phot on e mission c omputed tomography ( SPECT) i s a widely us ed i maging platform, relying on the detection of gamma emission from specific radioisotopes (64). Radiometals used for SPECT imaging include ${ }^{99 \mathrm{~m}} \mathrm{Tc},{ }^{111} \mathrm{In}$ and ${ }^{203} \mathrm{~Pb}(55,65)$. These are often employed because their gamma energies are low $(140 \mathrm{keV}-270 \mathrm{keV})$ and their halflives ( 6-52 h) a re s uited $\mathrm{f}$ or bi ological i maging a pplications. $\mathrm{P}$ ositron e mission tomography (PET) has received much attention of late because its sensitivity is 1-2 orders of $\mathrm{m}$ agnitude greater $\mathrm{t}$ han $\mathrm{S}$ PECT a nd $\mathrm{i} t$ allows $\mathrm{f}$ or qua ntification (66). $\mathrm{S}$ everal radiometals, including ${ }^{64} \mathrm{Cu},{ }^{68} \mathrm{Ga}$ and ${ }^{89} \mathrm{Zr}$ are commonly utilized for PET imaging. PET imaging o perates $\mathrm{b} y \mathrm{~d}$ etecting th e c oincident $\mathrm{g}$ amma $\mathrm{p}$ articles e mitted following a $\mathrm{n}$ annihilation of a positron emitted by the radionuclide and a surrounding electron (67). The half-lives range from $68 \mathrm{~m}$ in for ${ }^{68} \mathrm{Ga}$ to $78 \mathrm{~h}$ for ${ }^{89} \mathrm{Zr}$, allowing for a wide range of time scales. The choice of PET or SPECT imaging can be made based on availability of imaging equipment, cost and half-life however both moieties offer sensitive detection in vivo. Together, S PECT a nd P ET i maging provide s everal opt ions for in vivo imaging applications, a llowing $\mathrm{f}$ or a hos $\mathrm{t}$ of $\mathrm{i}$ maging ve ctors $\mathrm{f}$ or $\mathrm{i}$ mproved de tection a nd characterization of cancer. 


\section{Conclusion}

A ne ed e xists $f$ or nov el a nd i mproved i maging a gents $f$ or $d$ etection a nd characterization of $\mathrm{b}$ reast cancer. It $\mathrm{w}$ as $\mathrm{h}$ ypothesized in $\mathrm{t}$ his di ssertation $\mathrm{t}$ hat $\mathrm{ph}$ age display could be us ed to select peptides with optimal pharmacokinetics that $t$ arget and image human breast cancers based on a s pecific target or phenotype. Herein, the w ork presented describes the development of these targeted peptides for molecular imaging of breast cancer. The targets include the receptor ERBB2, tumor vasculature, and resistancesusceptible $\mathrm{h}$ uman $\mathrm{b}$ reast can cer $\mathrm{x}$ enografts. $\mathrm{E}$ ach $\mathrm{p}$ eptide $\mathrm{w}$ as $\mathrm{s}$ elected using in vivo phage display, and completely characterized in vitro prior to biodistribution and imaging analysis. In order to accomplish in vivo characterization, peptides were conjugated with DOTA and $\mathrm{r}$ adiolabeled $\mathrm{w}$ ith ${ }^{111} \mathrm{In}$. A $\mathrm{n}{ }^{111}$ In-DOTA ch elation strategy was ch osen because it is highly stable and well characterized. The data presented will demonstrate that in vivo phage display is capable of selecting peptides that are capable of imaging a wide variety of targets, and thus is a powerful tool for future imaging agent discovery. 


\section{CHAPTER 2}

\section{AFFINITY MATURATION OF AN ERBB2-TARGETED SPECT}

IMAGING PEPTIDE BY IN VIVO PHAGE DISPLAY 


\section{Introduction}

It is estimated that 1 in 8 women will develop breast cancer in their lifetime (1). Early d etection and c haracterization of br east $\mathrm{c}$ arcinomas w ill a llow for a $\mathrm{n}$ i mproved understanding of $\mathrm{i}$ ndividual $\mathrm{m}$ alignancy and $\mathrm{p}$ roper course of $\mathrm{t}$ reatment. $\mathrm{T}$ hus, ne $\mathrm{w}$ methods to visualize tumor associated antigens are being sought. The epidermal growth factor $\mathrm{t}$ yrosine kinase $\mathrm{r}$ eceptors $\mathrm{i}$ ncluding: e pidermal gr owth $\mathrm{f}$ actor $\mathrm{r}$ eceptor (EGFR)/HER1, E RBB2/HER2/neu, E RBB3/HER3 a nd E RBB4/HER4 ha ve received particular attention $\mathrm{b}$ ecause $\mathrm{o} f \mathrm{t}$ heir roles in $\mathrm{p}$ roliferation, $\mathrm{m}$ igration a nd $\mathrm{s}$ urvival signaling (10). ERBB2 acts p referentially as a dimerization partner, and breast tu mors over-expressing $\mathrm{t}$ he $\mathrm{r}$ eceptor are associated $\mathrm{w}$ ith $\mathrm{i}$ ncreased $\mathrm{m}$ alignancy and $\mathrm{p}$ oor prognosis (36). In breast cancer, ERBB2 is over-expressed in $20-30 \%$ of cases, and 80 $90 \%$ of breast cancers express the protein to some extent $(25,33)$.

The ability to differentiate tumors based on a molecular marker, such as ERBB2, would allow for detection and categorization of individual breast carcinomas based on the molecular composition of $t$ he $t$ umor. A lthough m onoclonal a ntibodies and a ntibody fragments $h$ ave high s pecificity and a ffinity for their $t$ argets, $s$ low cl earance and $p$ oor tumor penetration can hinder their effectiveness as imaging agents $(68,69)$. Peptides, in contrast, demonstrate rapid clearance and tumor penetration, but are limited by low target affinity (70). However, development of hi gh affinity, $t$ arget-specific $p$ eptides $h$ as $b$ een accomplished $t$ hrough $b$ acteriophage ( phage) di splay (71). E nrichment of $r$ are, hi gh affinity peptides is achieved through successive rounds of selection and amplification of 
phages di splaying target-avid pe ptides $(44,72)$. P reviously, a s ix a mino a cid pe ptide, KCCYSL, was discovered by phage di splay after in vitro selection with a recombinant ERBB2 ex tracellular d omain (43). $\mathrm{T}$ he a ffinity o $\mathrm{fK}$ CCYSL fo $\mathrm{r} i$ ts $\mathrm{t}$ arget $\mathrm{w}$ as approximately $300 \mathrm{nM}$, and it was able to clearly delineate ERBB2-expressing tumors in mice bearing MDA-MB-435 human breast carcinoma xenografts (48). The radiolabeled peptide was us ed to image ERBB2-expressing o varian and prostate carcinomas as well $(48,73)$. Biodistribution $\mathrm{s}$ tudies $\mathrm{r}$ evealed m odest $\mathrm{t}$ umor upt ake i $\mathrm{n}$ br east $\mathrm{c}$ arcinoma xenografts at $0.66 \%$ injected dose (ID)/g 2 h pos t-injection. However, non-target organ uptake, including kidney retention at 5.75\% ID/g 2 h pos t-injection, was likely too high for clinical applications. Thus, a means to improve the pharmacokinetic properties of the KCCYSL peptide was needed.

One method to improve the desired qualities of a peptide is through combinatorial evolution. $\mathrm{C}$ ombinatorial e volution is a $\mathrm{t}$ echnique ba sed on $\mathrm{t}$ he principle of a ffinity maturation in a ntibodies. In affinity maturation, primary a ntibodies produced w ith low intrinsic ta rget a ffinity a re $\mathrm{s}$ ubsequently $\mathrm{m}$ utated $\mathrm{i} \mathrm{n} \mathrm{t}$ heir $\mathrm{h}$ ypervariable $\mathrm{r}$ egions, ultimately leading to higher affinity antibodies (74). Addition of random amino acids to a core binding s equence $\mathrm{c}$ an be us ed to $\mathrm{m}$ imic the $\mathrm{m}$ utation of $\mathrm{h}$ ypervariable regions of antibodies in t he pur suit of hi gher a ffinity. $\mathrm{U}$ nlike a ffinity $\mathrm{m}$ aturation, c ombinatorial evolution is not limited to selection for increased affinity. Previously, a peptide with high target affinity for a disaccharide with low solubility was selectively evolved in vitro from a phage display lib rary with greater s olubility while ma intaining ta rget a ffinity (75). It follows that combinatorial evolution could be used to select for a novel property, such as in vivo target recognition, without impeding the original function of the core peptide. In 
order $\mathrm{t}$ o i mprove the in vivo pharmacokinetics a nd ima ging ability of the ERBB2targeting pe ptide, a novel pha ge $m$ icrolibrary, $t$ ermed "KCCYSL $m$ icrolibrary", $w$ as engineered. The phages in the microlibrary display the targeted peptide flanked by five and four random amino acids on the $\mathrm{N}$ - and C-termini, respectively. It was hypothesized that second generation peptides could be selected in vivo from the KCCYSL microlibrary with e nhanced pha rmacological pr operties i ncluding s pecific $t$ umor a ccumulation, reduced non-target organ uptake, and rapid clearance. 


\section{Materials and Methods}

\section{Materials}

Cell culture materials were purchased from Invitrogen (Carlsbad, CA). All other materials w ere pu rchased from S igma Chemical Co. ( St. Louis, MO) unless ot herwise specified.

\section{Mouse Strains and Handling}

Four- to 6 -week-old s evere combined i mmunodeficient ( SCID) o utbred mic e (Taconic, Germantown, NY) were maintained in a pproved pa thogen-free in stitutional housing. Animal studies were conducted as outlined in the NIH Guidelines for the Care and Use of Laboratory Animals and the Policy and Procedures for Animal Research of the Harry S. Truman Veterans Memorial Hospital. To establish solid tumors, MDA-MB435 hum an breast cancer c ells $\left(5 \times 10^{6}\right)$ were subcutaneously injected into the flank of SCID mice. Visible tumors $\left(\sim 1-3 \mathrm{~mm}^{3}\right)$ formed after approximately 5 weeks.

\section{Phage Selection and Characterization}

A 1 ibrary of doubl e-stranded o ligonucleotide cas settes $\mathrm{w}$ as co mmercially synthesized ( Sigma-Genosys, Inc., W oodlands, T X). E ach c assette $r$ etained the c ore ERBB2-binding a mino acid s equence K CCYSL, w hile di splaying additional 5 a nd 4 random amino acids adjacent to the parent peptide on the $\mathrm{N}$ - and $\mathrm{C}$-termini, respectively. Cassettes ligated into the fUSE5 vector, for display on the p III coat protein. Following 
ligation, the pha ge 1 ibrary $\mathrm{w}$ as $\mathrm{t}$ ransfected i nto $E$. coli and pr opagated a s de scribed previously (76).

\section{In Vivo Affinity Selection}

Phages with a propensity to bind nor mal tissues and proteins that are not tumor specific w ere c leared from the library in a nor mal m ouse, per pr evious m ethods (50). Briefly, $1 \times 10^{12}$ TU of the KCCYSL microlibrary were injected into normal CF-1 mice, incubated $15 \mathrm{~m}$ in, sacrificed, blood c ollected a nd injected phages recovered an $\mathrm{d}$ amplified. The pre-cleared phage pool then served as the starting library for subsequent selection pr ocesses. A $100 \mu \mathrm{L}$ s olution of $1 \times 10^{12}$ TU K CCYSL mic rolibrary w as intravenously injected in to MDA-MB-435 x enografted SCID mice. After 1h, mice were perfused to clear the tumor vasculature of unbound phage particles. Tumors were excised and homogenized be fore e xtraction of ph ages w ith a 2.5\% (w:v) $3-[(3-$ cholamidopropyl)dimethylammonio]-1-propanesulfonate (CHAPS) solution at $4^{\circ} \mathrm{C}$ for 2 h. The extracted phages were amplified and purified as previously described (50). In vivo selection was repeated for a total of four rounds of selection. A portion of the recovered phage $\mathrm{c}$ lones from the final s election were sequenced to as certain the foreign peptide sequences. P eptide s equences $\mathrm{w}$ ere an alyzed $\mathrm{b} y \mathrm{t}$ he $\mathrm{b}$ asic $\mathrm{l}$ ocal a lignment search $\mathrm{t}$ ool (BLAST) a nd sequence c omposition c omparison a nd s canner a nd $\mathrm{r}$ eporter of $\mathrm{t}$ arget unrelated proteins ( SAROTUP) to obt ain c lones of interest for further c haracterization $(77,78)$. Selected phage binding to MDA-MB-435 and 184A.1 cells w as performed as described previously (50). 


\section{Peptide Synthesis}

All pe ptides $\mathrm{w}$ ere s ynthesized us ing a n A dvanced $\mathrm{C}$ hem $\mathrm{T}$ ech 396 multiple peptide s ynthesizer by solid p hase F MOC ch emistry. B iotin and 1,4,7,10tetraazacyclododecane-1,4,7,10-tetraacetic a cid (DOTA) (Macrocyclic, Inc. D allas, TX) were covalently 1 inked to pe ptides t hrough the $\mathrm{N}$-terminus of a Gly-Ser-Gly (GSG) spacer.

\section{ERBB2 Peptide Binding Assay}

Recombinant human ERBB2 extracellular domain was produced and purified as previously described (43). In order to analyze peptide binding, $20 \mathrm{ng}$ of ERBB2 diluted in $\mathrm{Na}_{2} \mathrm{CO} 3$ buffer ( $\mathrm{pH}$ 9.6) was immobilized on Immulon ${ }^{\mathrm{TM}} 2 \mathrm{H} \mathrm{B} 96$-well mic rotiter E IA plates ( ImmunoChemistry Technologies Bloomington, $\mathrm{M} \mathrm{N}$ ) ove rnight a $4^{\circ} \mathrm{C}$. After removing the protein solution, the plates were blocked with BioFx synthetic block (BioFx Laboratories, Owing Mills, MD). The block was aspirated and wells were incubated with peptide s erially diluted i $\mathrm{n}$ T ris buf fered s aline a nd $0.1 \%$ Tween-20 ( $0.1 \%$ TBST). Following vi gorous w ashing with $0.1 \%$ T BST, w ells w ere incubated w ith s treptavidinconjugated horse radish peroxidase diluted 1:1000 in 0.1\% TBST. Wells were once again vigorously washed and bound peptide was visualized by the addition of 2,2'-azino-bis(3ethylbenzothiazoline-6-sulfonic acid) and absorbance read on a plate reader at $405 \mathrm{~nm}$.

\section{Fluorescent Microscopy}

MDA-MB-435 and 184A.1 cells dried onto microscope slides were blocked with $6 \%$ (w:v) BSA in TBS. Biotinylated peptides were diluted to $10 \mu \mathrm{M}$ with $0.1 \%$ TBST. 
Individual peptides were incubated with the cells for $1 \mathrm{~h}$, followed by washing with $0.1 \%$ TBST and incubation with Neutravidin Texas Red (Life Technologies, Rockville, MD) for $1 \mathrm{~h}$ a t room temperature. Following w ashing with $0.1 \%$ TBST, cells were visualized by an epifluorescent Nikon T1-SM inverted microscope (Nikon, Melville, NY).

\section{Radiolabeling and Peptide Cell Binding Assays}

DOTA-conjugated peptides were labeled with ${ }^{111}$ In and purified by RP-HPLC as previously described (48). MDA-MB-435 and 184A.1 cells were diluted to $1 \times 10^{6}$ cells in $200 \mu \mathrm{L}$ of DMEM with $0.1 \mathrm{mg} / \mathrm{mL}$ BSA. Cells $(200 \mu \mathrm{L})$ were incubated with $1 \times 10^{6} \mathrm{CPM}$ of peptide $(100 \mu \mathrm{L})$ at $37^{\circ} \mathrm{C}$ for the appropriate time, washed three times with ice-cold PBS with $1 \%$ BSA and counted via gamma counter.

\section{Radiolabeled Peptide Biodistribution}

${ }^{111}$ In-DOTA-GSG-1-D03 pe ptide w as di luted t o $1.85 \mathrm{M} \mathrm{Bq} / \mathrm{mL}$ in s terile P BS. Three mice bearing MDA-MB-435 tumors were intravenously injected and sacrificed at $30 \mathrm{~m}$ in, 1, 2 a nd $4 \mathrm{~h}$. Relevant or gans a nd $\mathrm{t}$ issues $\mathrm{w}$ ere $\mathrm{r}$ emoved for $\mathrm{w}$ eighing a nd counting by gamma c ounter. Uptake was r eported as p ercentage of i njected d ose $\mathrm{p}$ er gram of tissue $(\% \mathrm{ID} / \mathrm{g})$. F or bl ocking experiments, mice w ere injected with $100 \mu \mathrm{g}$ of unlabeled DOTA-GSG-1-D03 15 min prior to injection of radiolabeled peptide.

\section{MicroSPECT/CT Imaging}

An 11.1 MBq dose of ${ }^{111}$ In-DOTA-GSG-1-D03 was intravenously injected into a MDA-MB-435 tumor-bearing mouse. After $2 \mathrm{~h}$, the mouse was euthanized with carbon 36 
dioxide and imaged at the Biomolecular Imaging Center at the Harry S. Truman Veterans Memorial $\mathrm{H}$ ospital. Images w ere collected o vernight (7 h) using a $\mathrm{S}$ iemens Inveon Micro-SPECT/CT (Siemens, Knoxville, TN) equipped with mouse whole body $1.0 \mathrm{~m} \mathrm{~m}$ collimators. Image $\mathrm{d}$ ata $\mathrm{w}$ ere $\mathrm{p}$ rocessed $\mathrm{u}$ sing Inveon $\mathrm{R}$ esearch $\mathrm{W}$ orkplace $\mathrm{p}$ rocessing software and $\mathrm{f}$ an be am ( Feldkamp) f iltered ba ck pr ojection a lgorithms w ere us ed to reconstruct the $\mathrm{CT}$ tomographic image.

\section{Statistical Analysis}

Quantitative data were expressed as mean \pm standard error. Means were compared using 1 -way ANOVA and the Student $t$ test. $P$ values of less than $0.05 \mathrm{w}$ ere considered statistically significant. 


\section{Results}

\section{KCCYSL Microlibrary In Vivo Selection and Phage Characterization}

Following four rounds of selection, individual displayed sequences were analyzed by the BLAST and SAROTUP programs to de termine hom ology to hu man proteins as well a s p eptides f rom previously published ph age di splay selections. No s ignificant homology $t$ o know $n \mathrm{c}$ ancer-related $\mathrm{p}$ roteins $\mathrm{w}$ as $\mathrm{d}$ iscovered $\mathrm{b}$ y BLAST $\mathrm{s}$ earch, an $\mathrm{d}$ analysis by SAROTUP indicated that the peptides had not been previously published (77, 78). P revious work ha s de monstrated that a nalyzing pha ge a ffinity a nd s pecificity b y comparing target to non-target binding ratios is a successful predictor of in vivo tumor homing ability (50). Thus, 33 phage clones were arbitrarily selected and analyzed for the ability to $\mathrm{s}$ electively $\mathrm{b}$ ind M DA-MB-435 hum an br east $\mathrm{c}$ ancer $\mathrm{c}$ ells a nd $\mathrm{n}$ ot 184A .1 normal human breast epithelial cells. The cancer to ep ithelial cell binding ratio of each clone was compared to that of phages bearing the parent sequence, KCCYSL. Nine phage clones bound $\mathrm{w}$ ith a ratio gr eater than 1.56, w hich w as hi gher than K CCYSL ( Figure 2.1). Corresponding peptides from the 9 clones with higher binding ratios than KCCYSL from the cell binding assay were then synthesized.

\section{In Vitro Peptide Binding}

Although $\mathrm{t}$ he $\mathrm{p}$ rimary goal o $\mathrm{ft}$ he in vivo selection $\mathrm{w}$ as to imp rove th $\mathrm{e}$ pharmacokinetics of KCCYSL, it was also essential to ensure that the second generation peptides maintained binding to ERBB2. An ERBB2-peptide binding assay was 


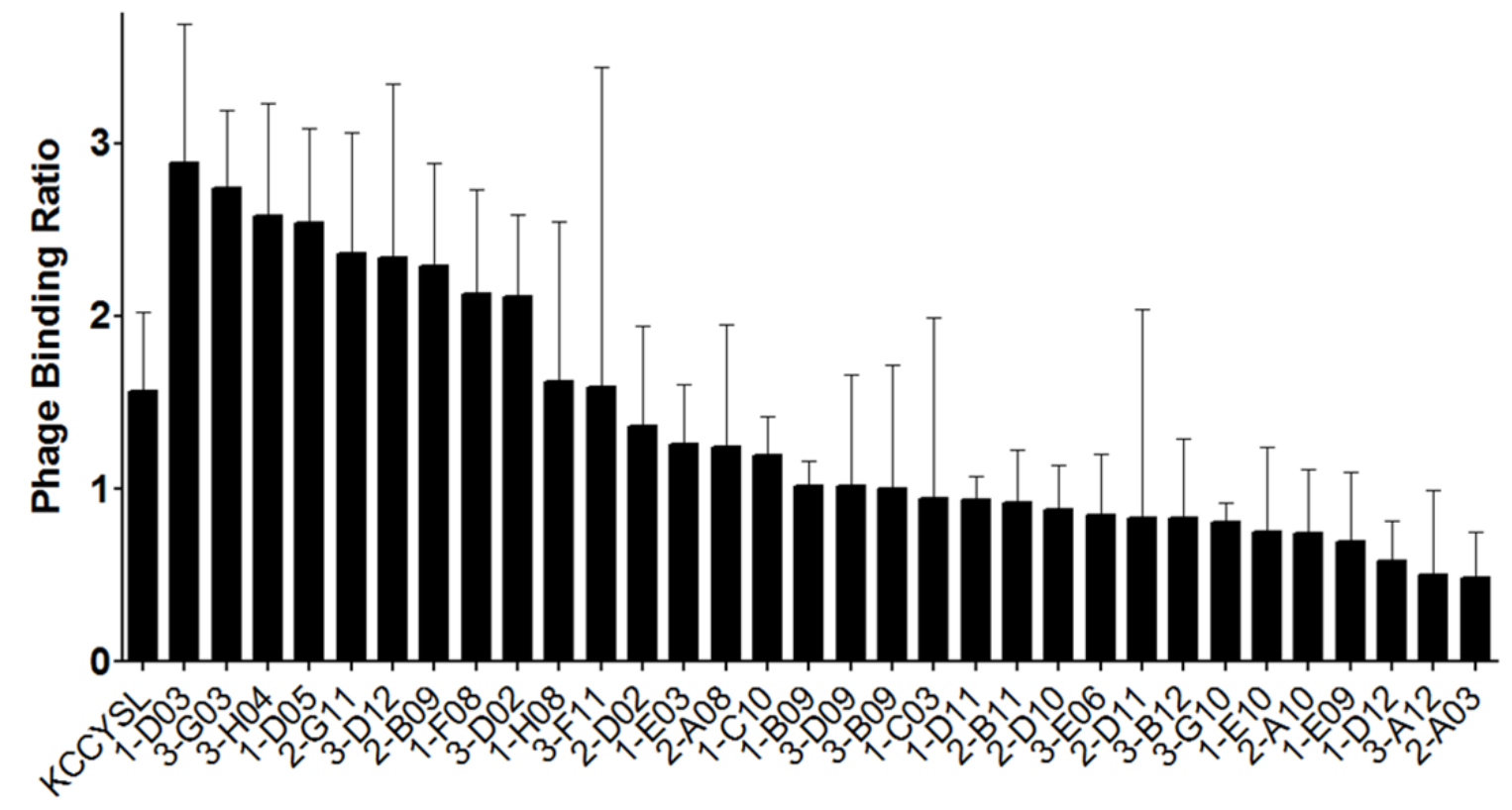

Figure 1.1 Individual phage popul ations were i ncubated $w$ ith e ither MDA-MB-435 human breast cancer or 184A.1 breast epithelial cells. Recovered phages were quantified by infection in E. coli. Binding was plotted as a ratio of cancer:normal cell binding. Error bars represent the standard deviation of 3 replicates. 
performed i $\mathrm{n}$ or der $\mathrm{t} \mathrm{o}$ a ssess $\mathrm{t}$ he af finity o f e ach $\mathrm{p}$ eptide for $\mathrm{i}$ ts $\mathrm{t}$ arget. $\mathrm{T}$ he $\mathrm{r}$ esults indicated $\mathrm{t}$ hat $\mathrm{t}$ wo pe ptides, 1 -D03 (MEGPSKCCYSLALSH) a nd 3 -G03 (GTKSKCCYSLRRSS) bound E RBB2 $\mathrm{w}$ ith apparent affinities of $236 \pm 83 \mathrm{nM}$ a nd $289 \pm 13 \mathrm{nM}$, respectively (Figure 2.2). Both peptides had a significantly higher apparent affinity for ERBB2 $(P<0.05)$ than the parent peptide KCCYSL $(351 \pm 32 \mathrm{nM})(48)$.

After confirming retained ERBB2 binding, the specificity of each peptide for the target $\mathrm{c}$ ell lin e, M DA-MB-435, and nor mal b reast e pithelial $\mathrm{c}$ ells $\mathrm{w}$ as investigated. 1 D03, 3-G03 and KCCYSL all successfully discriminated the target cell line from normal breast epithelial cells (Figure 2.3a). To further assess specificity, peptides were screened for bi nding $w$ ith a pa nel of $\mathrm{c}$ ultured $\mathrm{c}$ ells, i ncluding br east, pr ostate and pa ncreatic cancers. Figure 2.3b demonstrates 1-D03 bound only MDA-MB-435 cells, while 3-G03 appeared to bind all of the carcinoma cell lines tested, but with a lower affinity than for MDA-MB-435 cells.

\section{DOTA-Peptide Radiolabeling and In Vitro Cell Binding}

DOTA-(GSG)MEGPSKCCYSLALSH ( DOTA-1-D03) and DOT A(GSG)TKSKCCYSLRRSS ( DOTA-3-G03) p eptides w ere ch emically s ynthesized for radiolabeling with ${ }^{111}$ In. A nalysis of the RP-HPLC trace revealed $>95 \%$ radiochemical purity of 1 abeled pe ptides. R ecovery o $\mathrm{ft}$ he radiolabeled $\mathrm{p}$ eptide $\mathrm{f}$ ollowing H PLC purification was routinely $40-50 \%$ and stability in buf fer of both pe ptides w as greater than 24 


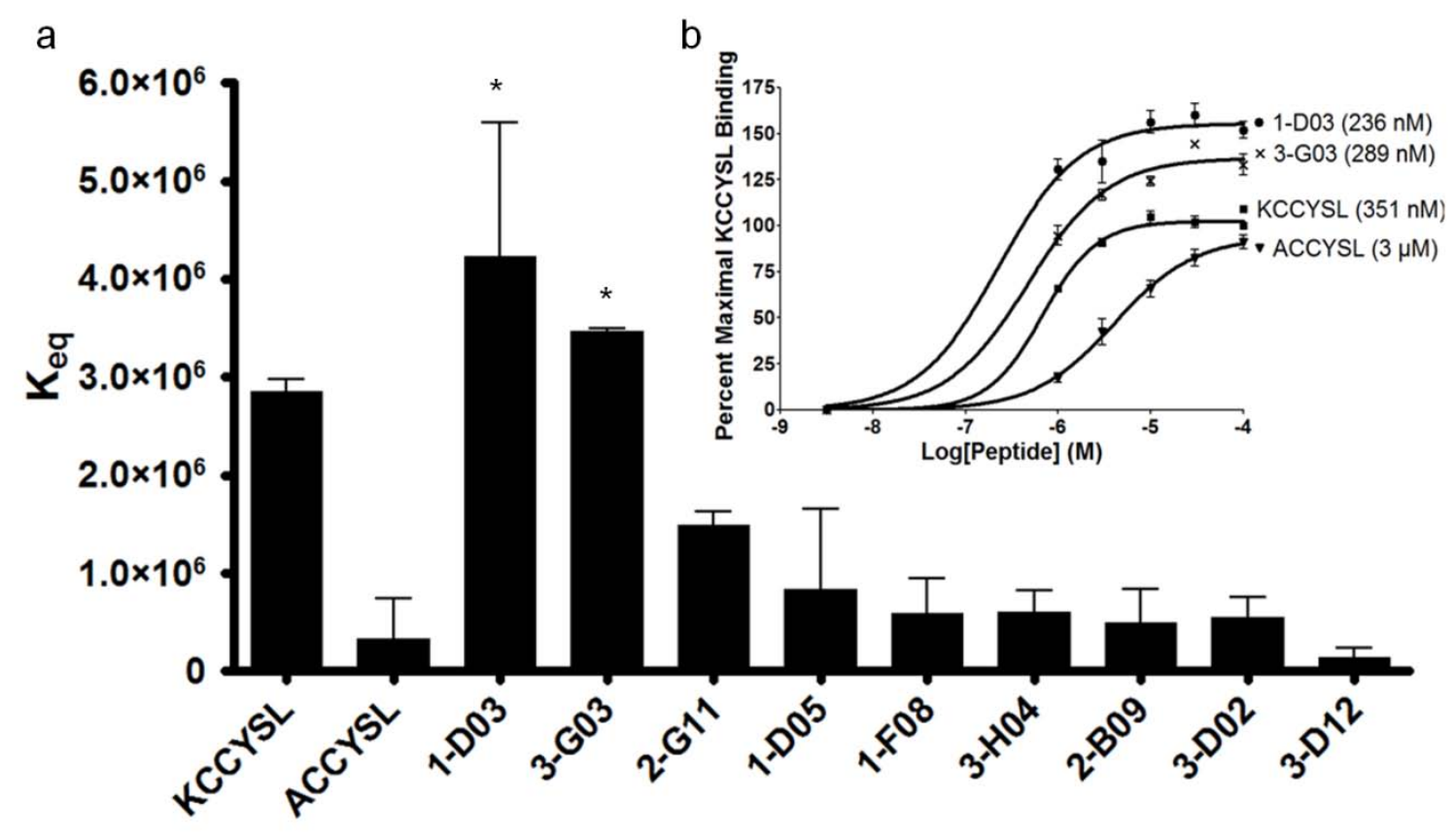

Figure 2.2 Serial d ilutions of biotinylated $\mathrm{p}$ eptide $\mathrm{w}$ ere in cubated $\mathrm{w}$ ith immo bilized human ERBB2 extracellular dom ain. Binding w as de tected b y i ncubation w ith H RPconjugated s treptavidin f ollowed b y c olorimetric s ubstrate. ( a) Binding a ffinities of peptides for ERBB2 plotted as the $\mathrm{K}_{\mathrm{eq}}$ or inverse $\mathrm{K}_{\mathrm{D}}$. (b) Individual binding data of the two highest affinity peptides (1-D03 and 3-G03), parent peptide (KCCYSL) and control peptide (ACCYSL). * $-P<0.05$ 


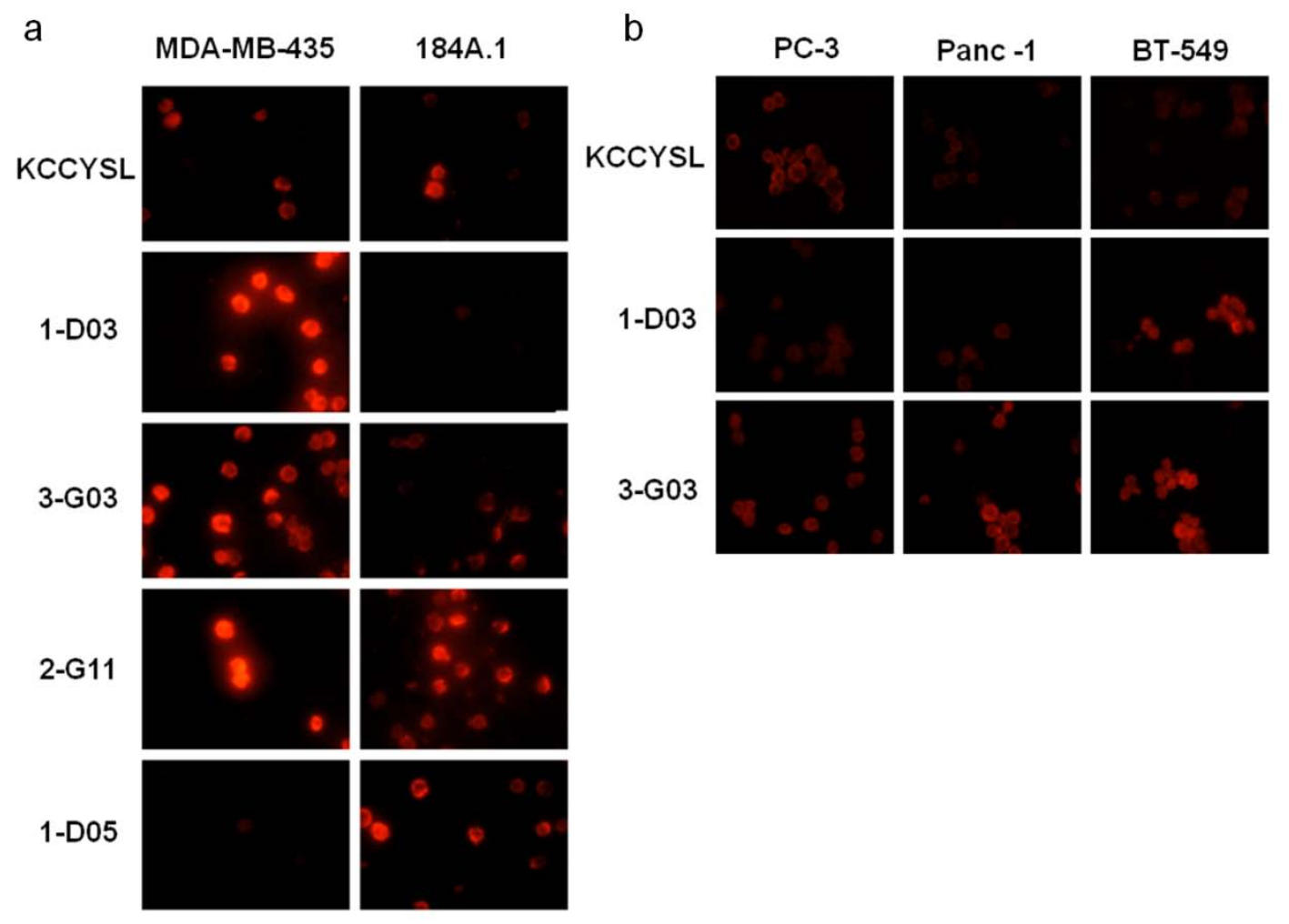

Figure 2.3 (a) Fluorescent i maging of anti-ERBB2 bi otinylated peptides against MDAMB-435 hum an b reast c arcinoma a nd 184A .1 nor mal br east e ndothelial c ells. ( b) Additional c ancer cell binding panel for top two clones (1-D03 a nd 3-G03) and parent peptide (KCCYSL). Cell lines include hum an prostate (PC-3), p ancreatic (Panc-1) and breast (BT-549) cancers. 
h. The half-life of the peptide incubated in mouse s erum $w$ as de termined to be greater than $24 \mathrm{~h}$ (not shown).

In o rder t o c onfirm $r$ etained s pecificity a nd affinity of the D OTA-conjugated peptides, in vitro cell binding was performed. Total bound peptide was used as a measure of a pparent a ffinity, while the ratio of MDA-MB-435 to 184A.1 binding was us ed as a measure of s pecificity. The results in Figure 2.4a di splay the cell binding of the ${ }^{111}$ Inlabeled pe ptides t o bot $\mathrm{h} \mathrm{c}$ ancer a nd e pithelial $\mathrm{c}$ ells. ${ }^{111}$ In-DOTA-KCCYSL bound $\mathrm{t} \mathrm{o}$ target cel ls $(1038 \pm 106 \mathrm{C} \mathrm{PM}) \mathrm{w}$ ith a s pecificity $\mathrm{r}$ atio of $3.49 .{ }^{111}$ In-DOTA-1-D03 demonstrated higher binding (1681 \pm 119 CPM) to MDA-MB-435 and specificity (7.44) than KCCYSL $(P<0.001)$. Similar binding of ${ }^{111}$ In-DOTA-1-D03 was achieved by ${ }^{111}$ InDOTA-3-G03 (1494 \pm 141 CPM) to MDA-MB-435 cells, but its specificity ratio (1.4) was less th an KCCYSL. A dditionally, serial dilutions of ${ }^{111}$ In-1-D03 incubated with MDAMB-435 c ells de monstrated s aturable bi nding ( Figure 2.4b) T hus, on ly ${ }^{111}$ In-DOTAGSG-1-D03 was chosen for in vivo radiolabeled peptide analysis.

\section{In Vivo Biodistribution}

The bi odistribution of ${ }^{111}$ In-DOTA-1-D03 pe ptide $\mathrm{w}$ as i nvestigated i $\mathrm{n} \mathrm{m}$ ice bearing MDA-MB-435 human breast tumor xenografts (Table 2.1). Tumor to blood ratios of the peptide reached $1.95 \pm 0.17$ at $1 \mathrm{~h}$ and $6.02 \pm 0.13$ at $2 \mathrm{~h}$ post-injection (Table 2.2). In order to compare pharmacokinetics between first and second generation peptides, tumor and organ uptake for KCCYSL and 1-D03 were compared at 1 and $2 \mathrm{~h}$ post-injection 


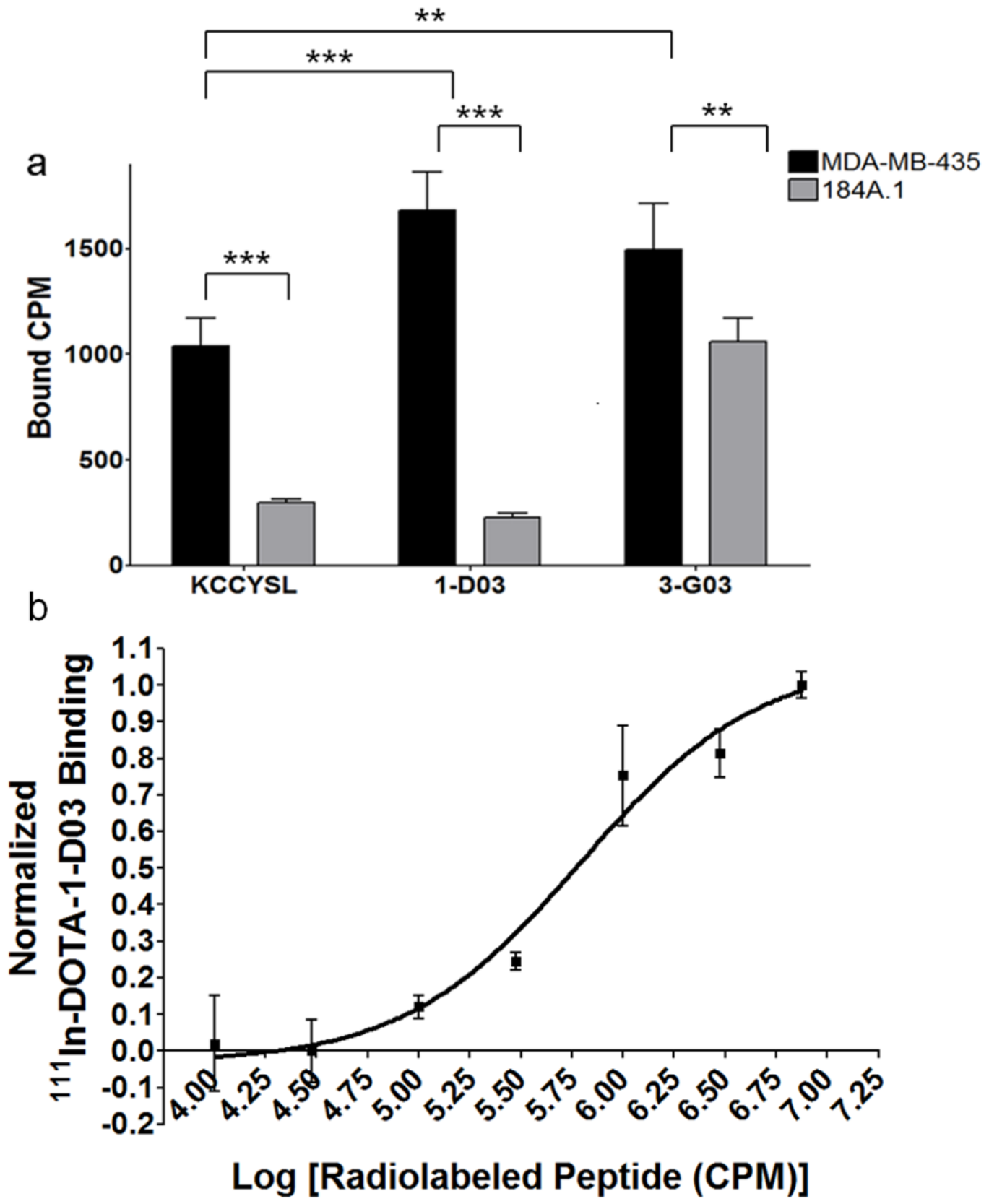

Figure 2.4 a) H PLC-purified ${ }^{111}$ In-DOTA-KCCYSL, 1 -D03 a nd 3 -G03 p eptides w ere incubated $w$ ith M DA-MB-435 hum an br east c arcinoma a nd 184A .1 br east e pithelial cells. Following washing, bound peptide was detected by gamma counter. Bars represent the mean of 3 replicates with standard deviation. (b) HPLC-purified ${ }^{111}$ In-DOTA-1-D03 
was s erial di luted a nd i ncubated $\mathrm{w}$ ith M DA-MB-435 $\mathrm{c}$ ells. F ollowing $\mathrm{w}$ ashing $\mathrm{c}$ ell binding was detected by gamma counter. Binding values were normalized for minimum and maximum $b$ inding values and pl otted as a fraction of $m$ aximum bi nding. CPM counts per min. ${ }^{* *}-P<0.01 ; * * * P<0.001$. 
Table $2.1-{ }^{111}$ In-DOTA-1-D03 Biodistribution

\begin{tabular}{|l|l|l|l|l|}
\hline Organ & $30 \mathrm{Min} \% \mathrm{ID} / \mathrm{g}$ & $1 \mathrm{~h} \% \mathrm{ID} / \mathrm{g}$ & $2 \mathrm{~h} \% \mathrm{ID} / \mathrm{g}$ & $4 \mathrm{~h} \% \mathrm{ID} / \mathrm{g}$ \\
\hline Tumor & $0.973 \pm 0.26$ & $0.664 \pm 0.09$ & $0.336 \pm 0.03$ & $0.144 \pm 0.04$ \\
\hline Blood & $1.542 \pm 0.42$ & $0.342 \pm 0.06$ & $0.056 \pm 0.01$ & $0.049 \pm 0.01$ \\
\hline Heart & $0.489 \pm 0.15$ & $0.130 \pm 0.03$ & $0.043 \pm 0.01$ & $0.036 \pm 0.01$ \\
\hline Lung & $1.195 \pm 0.32$ & $0.403 \pm 0.04$ & $0.213 \pm 0.05$ & $0.123 \pm 0.04$ \\
\hline Liver & $0.496 \pm 0.11$ & $0.174 \pm 0.02$ & $0.141 \pm 0.03$ & $0.144 \pm 0.02$ \\
\hline Spleen & $0.419 \pm 0.08$ & $0.132 \pm 0.02$ & $0.084 \pm 0.01$ & $0.083 \pm 0.02$ \\
\hline Stomach & $0.479 \pm 0.35$ & $0.338 \pm 0.50$ & $0.184 \pm 0.13$ & $0.079 \pm 0.04$ \\
\hline $\begin{array}{l}\text { Large } \\
\text { intestine }\end{array}$ & $0.265 \pm 0.08$ & $0.072 \pm 0.01$ & $0.297 \pm 0.09$ & $0.654 \pm 0.26$ \\
\hline $\begin{array}{l}\text { Small } \\
\text { intestine }\end{array}$ & $0.523 \pm 0.18$ & $0.220 \pm 0.07$ & $0.263 \pm 0.17$ & $0.128 \pm 0.50$ \\
\hline Intestines & $0.424 \pm 0.14$ & $0.159 \pm 0.05$ & $0.275 \pm 0.11$ & $0.352 \pm 0.13$ \\
\hline Kidneys & $7.557 \pm 1.82$ & $4.729 \pm 0.65$ & $4.746 \pm 0.31$ & $5.310 \pm 0.99$ \\
\hline Brain & $0.043 \pm 0.01$ & $0.017 \pm 0.01$ & $0.007 \pm 0.00$ & $0.005 \pm 0.00$ \\
\hline Muscle & $0.230 \pm 0.05$ & $0.049 \pm 0.01$ & $0.019 \pm 0.00$ & $0.019 \pm 0.00$ \\
\hline Pancreas & $0.475 \pm 0.01$ & $0.109 \pm 0.02$ & $0.031 \pm 0.01$ & $0.043 \pm 0.01$ \\
\hline Bone & $0.177 \pm 0.04$ & $0.087 \pm 0.04$ & $0.027 \pm 0.00$ & $0.028 \pm 0.01$ \\
\hline Skin & $0.851 \pm 0.23$ & $0.184 \pm 0.05$ & $0.071 \pm 0.02$ & $0.047 \pm 0.01$ \\
\hline & $30 \mathrm{Min} \% \mathrm{ID}$ & $1 \mathrm{H} \% \mathrm{ID}$ & $2 \mathrm{H} \% \mathrm{ID}$ & $4 \mathrm{H} \% \mathrm{ID}$ \\
\hline Urine & $84.59 \pm 3.76$ & $93.07 \pm 2.84$ & $95.46 \pm 0.07$ & $96.03 \pm 0.37$ \\
\hline
\end{tabular}

Mice $b$ earing M DA-MB-435 w ere i njected w ith ${ }^{111}$ In-DOTA-1-D03 an d s acrificed at designated time points. Organs were removed and c ounted by gamma counter. Peptide uptake is reported as $\% \mathrm{ID} / \mathrm{g} . \% \mathrm{ID} / \mathrm{g}-$ Percent injected dose/gram 
Table 2.2 - Radiolabeled Tumor:Organ Uptake Ratios

\begin{tabular}{|c|c|c|c|c|}
\cline { 2 - 5 } \multicolumn{1}{c|}{} & \multicolumn{2}{c|}{ Tumor:Organ 1 h P.I. } & \multicolumn{2}{c|}{ Tumor:Organ 2 h P.I. } \\
\cline { 2 - 5 } \multicolumn{1}{c|}{} & KCCYSL & $1-D 03$ & KCCYSL & 1-D03 \\
\hline Blood & $1.95 \pm 0.32$ & $1.94 \pm 0.65$ & $5.08 \pm 1.11$ & $6.01 \pm 0.81$ \\
\hline Heart & $3.54 \pm 0.53$ & $5.11 \pm 1.84$ & $6.60 \pm 2.75$ & $7.89 \pm 1.16$ \\
\hline Lung & $0.95 \pm 0.13$ & $1.65 \pm 0.49$ & $1.16 \pm 0.31$ & $1.57 \pm 0.36$ \\
\hline Liver & $3.12 \pm 0.54$ & $3.81 \pm 1.12$ & $3.00 \pm 0.52$ & $2.38 \pm 0.48$ \\
\hline Brain & $26.0 \pm 5.89$ & $39.0 \pm 15.8$ & $33.0 \pm 13.8$ & $49.7 \pm 11.7$ \\
\hline Muscle & $8.67 \pm 1.43$ & $13.6 \pm 4.78$ & $22.0 \pm 13.4$ & $17.9 \pm 3.44$ \\
\hline Bone & $3.90 \pm 0.54$ & $7.61 \pm 3.80$ & $7.33 \pm 4.48$ & $12.7 \pm 1.77$ \\
\hline
\end{tabular}

Mice $b$ earing M DA-MB-435 w ere i njected $w$ ith ${ }^{111}$ In-DOTA-1-D03 an d s acrificed at designated time points. Organs were removed and counted by gamma counter. Uptake is represented $b y t$ he $t$ umor $\%$ ID/g di vided b y $t$ he s pecific or gan $\%$ ID/g. P .I. - Post injection 
(Figure 2.5) (48). A reduction in non-specific organ binding was evident in just $1 \mathrm{h.} 1$ D03, i n c omparison t o K CCYSL ha d s ignificantly l ower h eart ( $0.13 \pm 0.03$ ve rsus $0.22 \pm 0.04 P<0.05)$, lung $(0.40 \pm 0.04$ versus $0.82 \pm 0.14 P<0.01)$, muscle $(0.04 \pm .01$ versus $0.09 \pm .02 P<0.05)$ and bone $(0.09 \pm 0.04$ versus $0.20 \pm 0.03 P<0.01)$ organ uptake. At $2 \mathrm{~h}$, the s pecificity $\mathrm{w}$ as $\mathrm{m}$ aintained, as $1-\mathrm{D} 03$ ha $\mathrm{d} 1$ ower residual pe ptide i $\mathrm{n}$ the bl ood $(0.06 \pm 0.01$ ve rsus $0.13 \pm 0.03 P<0.01)$. O rgan up take, i ncluding 1 ung $(0.21 \pm 0.05$ versus $0.57 \pm 0.18 P<0.01)$ a nd 1 iver $(0.144 \pm 0.03$ ve rsus $0.22 \pm 0.02 P<0.05)$, c ontinued to be lower than KCCYSL. A dditionally, total kidney retention for the 1-D03 was $4.73 \pm 0.31$ $\% \mathrm{ID} / \mathrm{g}$ a t $1 \mathrm{~h}$ a nd $4.75 \pm 0.91 \% \mathrm{ID} / \mathrm{g}$ a t $2 \mathrm{~h} \quad$ (Table 2.3), w hich $\mathrm{w}$ as s ignificantly le ss $(P<0.05)$ than KCCYSL kidney uptake at $2 \mathrm{~h}(5.75 \pm 0.69 \% \mathrm{ID} / \mathrm{g})$.

\section{SPECT/CT Tumor Imaging}

The imaging capabilities of ${ }^{111}$ In-DOTA-1-D03 were investigated in mice bearing MDA-MB-435 x enografts. Whole bod y S PECT/CT w as pe rformed $2 \mathrm{~h}$ following injection of 1.85 MBq of ${ }^{111}$ In-DOTA-1-D03 peptide. Images (Figure 2.6a) demonstrate clear tumor uptake of the radiotracer. In order to confirm specificity of the peptide for the tumor x enograft, $100 \mu \mathrm{g}$ unlabeled 1-D03 was injected $15 \mathrm{~min}$ prior to radiolabeled 1D03. P re-injection of c old p eptide e liminated detectable radiolabeled p eptide u ptake in the S PECT/CT ( Figure 2.6b), s uggesting t umor s pecific upt ake of 1-D03. K idney retention of radiolabeled peptide was consistent with biodistribution data. The inability to 
reduce ki dney upt ake by $\mathrm{p}$ reinjection with unl abeled pe ptide s uggests s equence independent renal retention of radiolabeled peptides. 

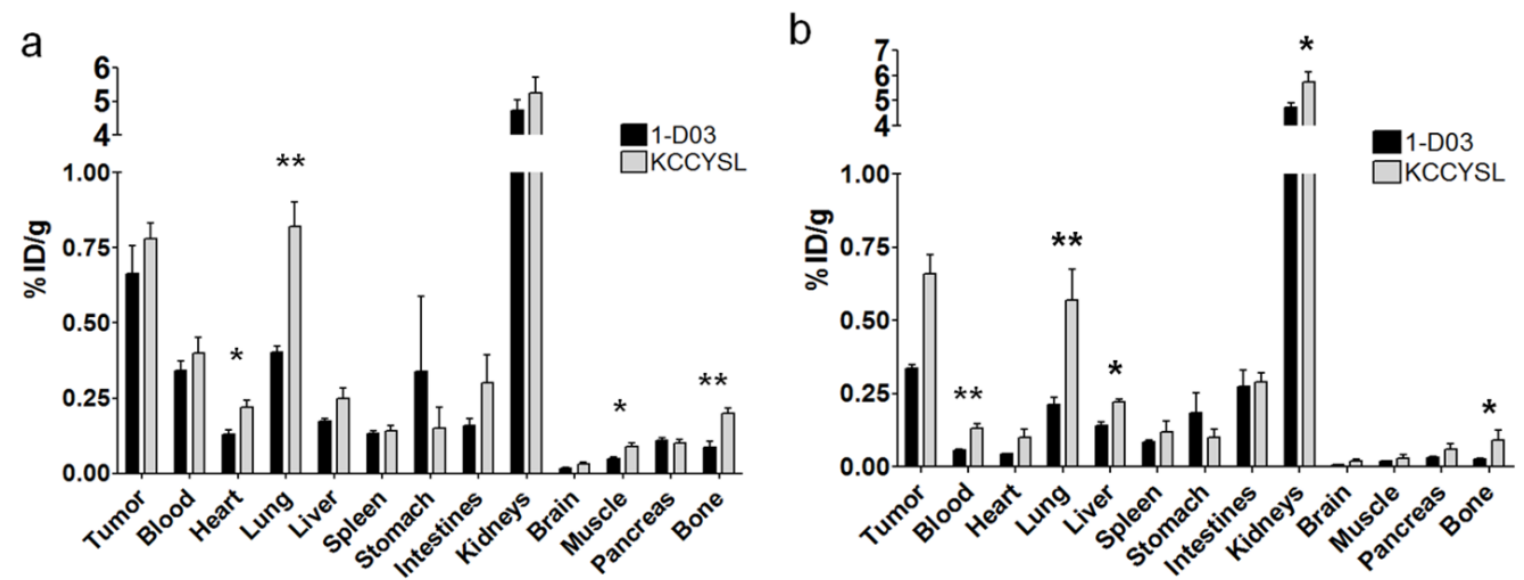

Figure 2.5 HPLC-purified ${ }^{111}$ In-DOTA-1-D03 was i njected i nto MDA-MB-435 t umor bearing S CID mic e. At the s pecified time, mice w ere s acrificed, o rgans r emoved an $\mathrm{d}$ peptide uptake analyzed by gamma counter. Bars represent the tumor:organ ratio at a) $1 \mathrm{~h}$ and b) $2 \mathrm{~h}$ post-injection with standard error of 4 replicates. ${ }^{*}-P<0.05$; ${ }^{* *}-P<0.01$. 
TABLE 2.3 - Radiolabeled Peptide Kidney Retention

\begin{tabular}{|c|c|c|}
\hline Time P.I. & 1-D03 Kidney \%ID/g & KCCYSL Kidney \%ID/g \\
\hline $1 \mathrm{~h}$ & $4.729 \pm 0.654$ & $5.26 \pm 0.78$ \\
\hline $2 \mathrm{~h}$ & $4.746 \pm 0.309 *$ & $5.75 \pm 0.69$ \\
\hline $4 \mathrm{~h}$ & $5.309 \pm 0.994$ & $6.45 \pm 0.69$ \\
\hline
\end{tabular}

Mice $b$ earing M DA-MB-435 w ere i njected $w$ ith ${ }^{111}$ In-DOTA-1-D03 an d s acrificed at designated time points. O rgans w ere removed and c ounted by gamma c ounter. Kidney uptake at s pecific time points is c ompared. \%ID/g - Percent injected dose/gram; P.I. Post injection; * $-P<0.05$. 

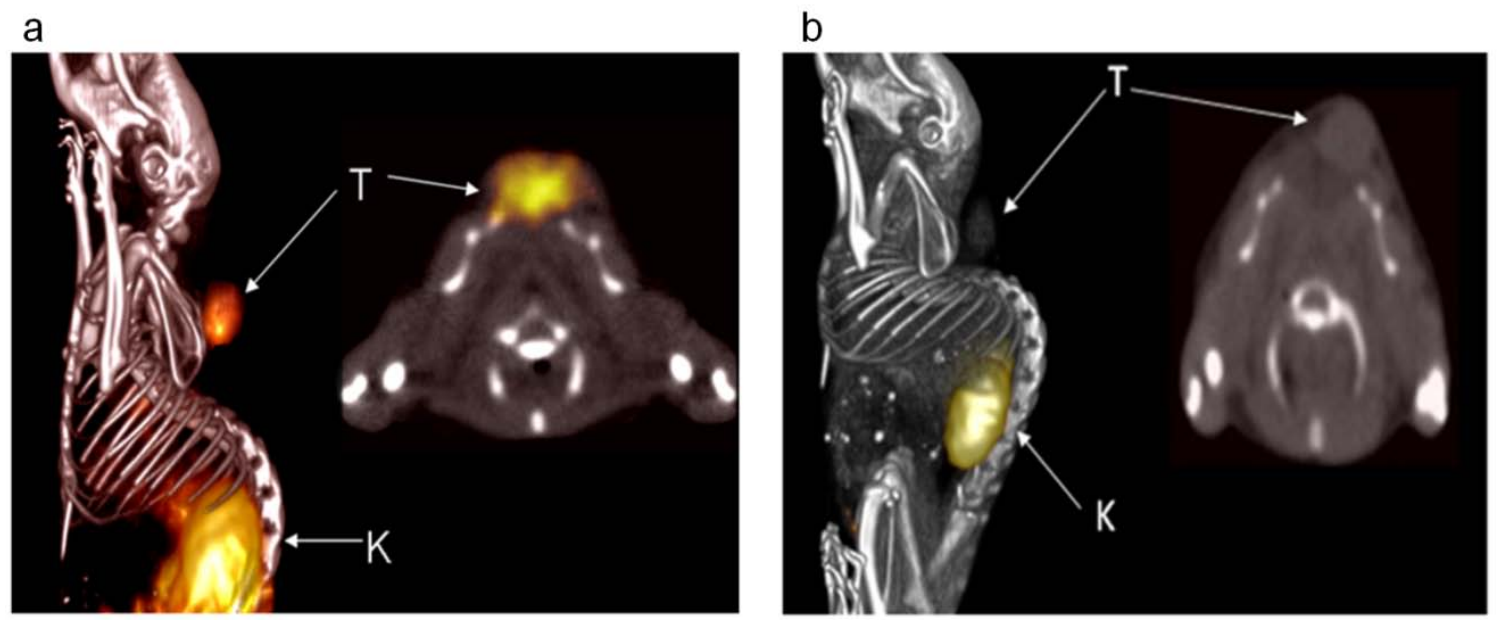

Figure 2.6 (a) A S CID mouse b earing MDA-MB-435 human b reast can cer x enografts was injected with HPLC-purified ${ }^{111}$ In-DOTA-1-D03 and SPECT images were collected $2 \mathrm{~h} \mathrm{f}$ ollowing i njection. ( b) An M DA-MB-435 $\mathrm{t}$ umor be aring S CID $\mathrm{m}$ ouse w as preinjected with $100 \mu \mathrm{g}$ of unlabeled DOTA-1-D03 peptide followed by ${ }^{111}$ In-DOTA-1D03 $15 \mathrm{~m}$ in a fter unl abeled pe ptide i njection. S PECT/CT i maging $\mathrm{w}$ as pe rformed $2 \mathrm{~h}$ post injection. Arrows from $(\mathrm{T})$ indicate tumors and $(\mathrm{K})$ indicate kidneys. 


\section{Discussion}

ERBB2 is a $\mathrm{m}$ ediator of carcinogenesis and is the ta rget o $\mathrm{ftw}$ o clinically approved therapeutic antibodies, pertuzumab and trastuzumab, which bind to domains II and IV of the receptor, respectively $(25,35,38)$. Where pertuzumab acts by inhibiting dimerization of $\mathrm{t}$ he $\mathrm{r}$ eceptor, $\mathrm{t}$ rastuzumab a cts $\mathrm{t}$ hrough a num ber of pr oposed mechanisms, including inhibiting ERBB2 shedding and antibody dependent cytotoxicity (79). Although the antibodies are successful therapeutics, the large size of m onoclonal antibodies renders them less effective as radioimaging or radiotherapeutic agents, due to long $\mathrm{c}$ irculation time $\mathrm{s}$ a nd $\mathrm{c}$ learance o rgan accumulation (51). I $\mathrm{n}$ c omparison, a radiolabeled ERBB2 binding peptide, such as KCCYSL, could simultaneously detect and characterize a car cinoma; because its rapid pharmacokinetic profile is more suitable for imaging than an antibody. Additionally, an ERBB2 targeting pe ptide could be us ed to probe a ntigen s tatus dur ing therapeutic intervention, which w ould a llow for $r$ eal t ime assessment of target status. For example, KCCYSL has been demonstrated to bind cells expressing moderate ERBB2 levels, however it does not bind cancer cells devoid of the receptor (80). In order for SPECT or PET imaging peptides to gain relevance clinically, it is imp ortant that th eir pharmacokinetic properties be opt imized to provide the hi ghest tumor dos e w ith $\mathrm{m}$ inimal non -target upt ake. $\mathrm{C}$ urrent $\mathrm{r}$ adiolabeled pe ptide m odification strategies include amino acid substitution, cyclization, and spacer or chelate modification $(54,81,82)$. For example, substitution of tyrosine for phenylalanine in the somatostatin- 
mimicking $\mathrm{p}$ eptide (D)-Phe ${ }^{1}$-Thy ${ }^{3}$-octreotide ( DOTATOC) i ncreased t umor upt ake greater than 9 fold (83). However, amino acid variation is not always well tolerated by a peptide, as ch anging glutamic aci $\mathrm{d} r$ esidues i $\mathrm{n} \mathrm{m}$ inigastrin an alogues reduced $\mathrm{t}$ umor uptake $50 \%$ (84). A nother s trategy t o e nhance a ffinity a nd s tability of a pe ptide i s through cyclization. The alpha-melanocyte s timulating h ormone (ReCCMSH) peptide had a greater than 4 fold increase in tumor to blood and over a 100 fold increase in tumor to $\mathrm{mu}$ scle $\mathrm{r}$ atios $\mathrm{w}$ hen it $\mathrm{w}$ as $\mathrm{c}$ yclized $\mathrm{b}$ y coordination $\mathrm{w}$ ith $\mathrm{r}$ henium $\mathrm{o}$ xide (85). Interestingly, cysteine-based di sulfide cyclization did not enhance, and, in fact, reduced total tu mor up take a nd $\mathrm{t}$ umor $\mathrm{t} \mathrm{o} \mathrm{b}$ lood $\mathrm{r}$ atios o $\mathrm{fthe}$ pe ptide. In $\mathrm{c}$ ases where $\mathrm{r}$ ational modification strategies are unsuccessful, a combinatorial approach, such as in vivo phage display may offer a solution to an otherwise difficult problem.

In this study, as well as ot hers, in vivo selection did not result in a consensus sequence or motif for t umor targeting $(50,86)$. Although e mergence of a predominant sequence is traditionally a m easure of a s uccessful pha ge di splay selection, the large diversity of selected phages may have resulted from the complex target environment (87). In addition, the core binding sequence, KCCYSL, may have been sufficient if not optimal to target each phage to the tumor. This is supported by the ERBB2 peptide binding data, in which the highest affinity second generation peptides bound with similar affinity as the parent pe ptide. T he i nability t o s elect hi gher a ffinity pe ptides $c$ ould $b$ e $t$ he $r$ esult of KCCYSL being the optimal ERBB2 targeting peptide or evidence that the receptor exists in c lose pr oximity t o a num ber of ot her $\mathrm{m}$ olecules or bi nding pa rtners, c reating a heterogeneous target. Although individual second generation peptide affinity for ERBB2 was not hi gher than K CCYSL, 9 pha ge clones e xhibited hi gher E RBB2-expressing 56 
tumor to normal breast cell binding ratios compared to the parent peptide. Higher affinity for cultured breast carcinoma cells, in combination with similar affinity as KCCYSL to purified target $s$ uggests th at th e imp roved cancer $t$ argeting ab ility of $t$ he $s$ econd generation pha ges a nd corresponding pe ptides may r esult from i mproved de tection of ERBB2 i $\mathrm{t}$ he c omplex c ellular e nvironment, a s oppos ed t o e nhanced affinity. This notion is bolstered b y fluorescent $\mathrm{m}$ icroscopy data, $\mathrm{w}$ hich $\mathrm{r}$ evealed hi gher apparent binding of both 1-D03 and 3-G03 peptides to the target MDA-MB-435 breast carcinoma cells t han K CCYSL. 1-D03 pe ptide a lso e xhibited e xceptional s pecificity, in t hat it displayed low to no binding to normal breast epithelial cells or to other cancer cell lines tested. Together, these results are evidence that in vivo phage display affinity maturation may offer the unique advantage of presenting a target in its physiological configuration, allowing for selection of peptides otherwise unattainable by in vitro selection protocols.

The pur pose of our $\mathrm{s}$ tudies $\mathrm{w}$ as $\mathrm{t} \mathrm{o} \mathrm{c}$ reate an i mproved E RBB2-targeted radioimaging $\mathrm{p}$ eptide ba sed on a K CCYSL core s equence. The $t$ wo pe ptides with the highest a ffinity for E RBB2, 1 -D03 and 3 -G03, w ere s ynthesized c onjugated t o t he macrocyclic chelator DOTA for radiolabeling with ${ }^{111}$ In. The use of DOTA radiolabeled with ${ }^{111}$ In served two purposes. Chelation of ${ }^{111}$ In by DOTA is highly stable and has been used $\mathrm{c}$ linically for pe ptides, a nd the s table chelation a llowed $\mathrm{f}$ or $\mathrm{f}$ ocus on pe ptide pharmacokinetics, without non-target uptake artifacts due to free radiometal (55). It was necessary to reanalyze peptide binding following chelator conjugation and radiolabeling, as both have sometimes been observed to alter peptide properties (65). Similar to results with biotinylated peptides, radiolabeled 1-D03 bound with higher affinity and specificity than radiolabeled K CCYSL to M DA-MB-435 cells. A lthough 3-G03 b ound w ith hi gh 
affinity to target cells, it was less specific than KCCYSL and was eliminated from in vivo characterization. The decreased specificity of 3-G03 may be the result of the a dditional amino acid sequence of the second generation peptide interfering with binding to ERBB2 on the cell surface. Radiolabeled 1-D03 demonstrated MDA-MB-435 saturable binding, which in dicated specificity for its target. The combination of specific and hi gh affinity binding of the ${ }^{111}$ In-DOTA-conjugated 1 -D03 peptide to M DA-MB-435 c ells provided the necessary evidence to continue into animal studies.

Nude mice bearing MDA-MB-435 human breast tumor xenografts were used for biodistribution studies with ${ }^{111}$ In-DOTA-1-D03. Although MDA-MB-435 hum an breast cancer cells express low to moderate levels of ERBB2, KCCYSL has been demonstrated to i mage a range of tumors that express m oderate to high levels of ERBB2, including MDA-MB-435, hum an ovarian O V-CAR 3, and hum an prostate P C-3 human prostate cancers $(48,73)$, which express lower levels of ERBB2 than hum an breast cancer cell lines such as BT-474 and S K-BR-3 (88). Since most human can cers express moderate levels of E RBB2, the MDA-MB-435 a nimal model $w$ as us ed as a s ensitive means to gauge the new i maging peptides (33). In c ontrast to in vitro data, 1 -D03 had s lightly lower tumor uptake than KCCYSL at both 1 and $2 \mathrm{~h}$ post-injection. One reason for the slightly diminished tumor uptake may have been the rapid overall clearance of 1-D03. In fact, despite reduced overall tumor uptake, 1-D03 had an equal tumor to blood ratio at $1 \mathrm{~h}$ and a $\mathrm{s}$ ignificantly hi gher $\mathrm{t}$ umor $\mathrm{t} \mathrm{o} b$ ood $\mathrm{r}$ atio a $\mathrm{t} 2 \mathrm{~h}$ pos t-injection $\mathrm{c}$ ompared $\mathrm{t} \mathrm{o}$ KCCYSL. The tumor to blood ratio of $1-\mathrm{D} 03$ at $2 \mathrm{~h}$ was $6: 1$, which compares well with the 7.6: $1 \mathrm{t}$ umor $\mathrm{t}$ o bl ood $\mathrm{r}$ atio of c linically approved oc treoscan, a nd is hi gher $\mathrm{than}$ radiolabeled analogs of minigastrin, bom besin and va soactive in testinal peptide, a ll of 
which ha ve be en e xamined $\mathrm{i} n$ hum an $\mathrm{s}$ tudies (89-92). In a ddition $\mathrm{t}$ or apid bl ood clearance, n on-target or gan uptake was significantly reduced in a number of organs at both 1 a nd $2 \mathrm{~h}$ post-injection for 1 -D03 in comparison to KCCYSL. When examining non-target $\mathrm{u}$ ptake, $\mathrm{s}$ uccessful ima ging $\mathrm{p}$ eptides $\mathrm{s}$ hare two $\mathrm{p}$ roperties: they minimize exposure of $\mathrm{r}$ adiosensitive or gans and they have 1 imited a ccumulation $\mathrm{i} n$ a reas surrounding the tissue of interest in or der to provide the hi ghest t umor to background ratios pos sible. 1 -D03 exhibited both of these properties. For the radiosensitive organs such a s the bone, the t umor to bone $r$ atio was increased from 7:1 to 12:1 for 1 -D03 compared t o K CCYSL, at $2 \mathrm{~h}$ post-injection. The or gans s urrounding t he br east, including the he art a nd 1 ungs, a lso displayed s ignificant in creases in tu mor to o rgan contrast of $20 \%$ and $40 \%$, r espectively. T otal ki dney $r$ etention, w hich $\mathrm{c}$ an 1 imit the effectiveness of radiolabeled peptides due to toxicity, was also reduced by $\sim 20 \%$ in the second generation pe ptide. $T$ hese $\mathrm{r}$ esults demonstrate th at the in vivo phage di splay affinity $\mathrm{m}$ aturation di $\mathrm{d}$ i ndeed $\mathrm{i}$ mprove $\mathrm{K}$ CCYSL pha rmacokinetics, in that tumor specificity was enhanced and non-target retention was reduced, which was the goal of the phage display selection.

The most critical component of a targeted peptide is the ability to clearly visualize tumors in vivo. In order to analyze its imaging properties, ${ }^{111}$ In-labeled 1-D03 was used in SPECT/CT and c learly di splayed $t$ umor upt ake. S ubsequent blocking $\mathrm{s}$ tudies $\mathrm{w}$ ith unlabeled pe ptide confirmed s pecificity. Although 1 -D03 $r$ educed kidney $r$ etention, uptake was still very prominent in the SPECT image. Ultimately, reduction or elimination of ki dney upt ake b y peptide modification would e nhance $\mathrm{t}$ he pe ptide a $\mathrm{s}$ bot $\mathrm{h}$ a radioimaging and therapeutic ag ent. A synergistic e ffort combining phage display with 
successful strategies such as coinjection with cationic amino acids, succinylated gelatin, or bovine serum albumin fragments in addition to spacer or chelate modification could be utilized in future studies $(54,81,93,94)$.

The results presented here demonstrate in vivo phage display affinity maturation of a cancer-targeting peptide. Although in vivo selection c learly improved the pharmacokinetics of 1-D03, it may be w orthwhile to consider the merits of combining both in vivo and in vitro affinity $\mathrm{m}$ aturation $\mathrm{w}$ hen $\mathrm{m}$ odifying a targeted pe ptide. By combining both techniques in a selection, one may capture the benefits of both the target affinity increase of in vitro selections, in addition to the pharmacokinetic enhancements afforded by in vivo selection. Such a strategy may in the future produce improvements seen in DOTATOC and ReCCMSH $(83,85)$. 


\section{Conclusion}

To the best of our knowledge, we have demonstrated the first use of in vivo phage display a ffinity $m$ aturation t o i mprove the pha rmacokinetic pr operties of a $\mathrm{E}$ E RBB2targeted SPECT imaging peptide. Phages and corresponding peptides were evaluated for both E RBB2 and hum an br east carcinoma bi nding in vitro. O ne peptide, 1 -D03, wa s radiolabeled with ${ }^{111}$ In and us ed in biodistribution and S PECT i maging s tudies. 1-D03 demonstrated improved t umor t o non -target u ptake in blood, bone, he art a nd 1 ung in comparison to the first generation KCCYSL peptide. In fact, tumor to blood ratios were comparable to those for c linically tested and a pproved pe ptides. These results indicate that in vivo phage display can be utilized to optimize the pharmacokinetics of peptides for radioimaging applications. Accordingly, 1-D03 may serve as a us eful clinical probe for ERBB2-expressing malignancies. 


\section{Acknowledgments}

The a uthors w ould 1 ike to acknowledge the c ontributions of Jessica N ewton-Northup, Marie T. Dickerson and the VA Biomolecular Imaging Core. This material is based upon work supported (or supported in part) by the Department of Veterans Affairs, Veterans Health A dministration, $\mathrm{O}$ ffice of $\mathrm{R}$ esearch and $\mathrm{D}$ evelopment, Biomedical L aboratory Research and Development, Clinical S ciences R esearch and Development including the Cooperative $\mathrm{S}$ tudies $\mathrm{P}$ rogram, $\mathrm{R}$ ehabilitation $\mathrm{R}$ esearch and Development $\mathrm{S}$ ervice, and Health Services Research and Development through a VA Merit Award (I01BX000964). Additional support provided by an NIBIB Training Grant NIBIB 5 T32 EB004822. 


\title{
CHAPTER 3
}

Identification of a Peptide from In Vivo Bacteriophage Display with

Homology to EGFL6, A Candidate Tumor Vasculature Ligand in

\author{
Breast Cancer
}




\section{Introduction}

Much e ffort ha $\mathrm{s} b$ een $\mathrm{pl}$ aced on i dentifying $t$ he pr ocess of hum an $t$ umor vascularization (95). A s t umor s ize i ncreases, new vasculature i s r equired t o provide blood flow and nutrients to the growing malignancy, a process termed angiogenesis (96). The network of blood vessels in each organ, including tumors, is differentiated by tissue specific expression of ligands an $\mathrm{d}$ receptors (97). These proteins s erve as a m olecular address, and in the case of tumorigenesis, may prove effective for delivery of imaging agents or c ytotoxic dr ugs (98). Although t umor va sculature proteins $\mathrm{s}$ uch a s va scular endothelial $g$ rowth $\mathrm{f}$ actor, $\alpha_{\mathrm{v}} \beta_{3}$ integrin, an $\mathrm{d} \mathrm{p}$ latelet $\mathrm{d}$ erived growth $\mathrm{f}$ actor ar e w ell known, resistance to therapies targeting these proteins reveals that tumor vasculature is a complex system that remains incompletely characterized (99). The ability to identify and help va lidate no vel ligands a nd $\mathrm{t}$ heir $\mathrm{c}$ orresponding receptors responsible $\mathrm{f}$ or $\mathrm{t}$ umor angiogenesis would prove a dvantageous. N ot o nly c ould the ligands s erve as pot ential targeting ve ctors $\mathrm{f}$ or imaging applications, bu $\mathrm{t}$ bl ockade o f $\mathrm{r}$ eceptors $\mathrm{c}$ ould pr event increased blood supply for a tumor and limit its growth.

In or der $\mathrm{t} o$ de termine $\mathrm{n}$ ovel $\mathrm{c}$ ancer bi omarkers, $\mathrm{t}$ echniques $\mathrm{m}$ ust $\mathrm{b}$ e us ed $\mathrm{t}$ hat illuminate can cer-specific 1 igands an $\mathrm{d} r$ eceptors. $\mathrm{D}$ eciphering $\mathrm{t}$ he $\mathrm{d}$ ifferential $\mathrm{p}$ rotein expression be tween $\mathrm{m}$ alignant a nd non -malignant $\mathrm{c}$ ells is of ten a ttempted us ing hi gh throughput $\mathrm{s}$ creening $\mathrm{m}$ ethods, due $\mathrm{t} o$ the $\mathrm{c}$ omplex na ture of $\mathrm{t}$ he $\mathrm{t}$ umor microenvironment. $\mathrm{O}$ ne pr ocess for i dentifying nov el $\mathrm{c}$ ancer-specific 1 igands and 
receptors is m RNA profiling, which has be en us ed to i dentify genes with significantly higher $t$ ranscription l evels in tumors (100-102). H uman cancer $t$ ranscriptional p rofiles have served to create a reservoir of hypothetical tu mor interacting transcripts, encoding for tumor vasculature proteins such as adlican, collagen type-XI a lpha-1, glycoprotein M6B and epidermal growth $\mathrm{f}$ actor-like $\mathrm{d}$ omain mu ltiple 6 ( egfl6) (103). The egfl6 transcript, in pa rticular, was $\mathrm{f}$ irst $\mathrm{r}$ eported i $\mathrm{n}$ s everal $\mathrm{f}$ etal $\mathrm{t}$ issues an $\mathrm{d}$ human $\mathrm{g}$ lioma tumor bi opsy s amples using a hi gh $t$ hroughput $\mathrm{s}$ creening $\mathrm{b}$ y h ybridization $\mathrm{t}$ echnique (104). Recently, several human tumor biopsy transcription analyses have indicated egfl6 mRNA is e xpressed a th igh le vels in me ningioma, $\mathrm{g}$ lioma and ova rian a nd br east carcinomas, while levels in normal tissues were virtually undetectable $(20,100,102,105$, 106). The reports of tumor specific egfl6 expression suggest a need for investigation into its possible role in tumorigenesis.

The egfl 6 gene e ncodes $\mathrm{f}$ or a $\mathrm{n}$ a pproximately $60 \mathrm{kD}$ a s ecreted protein $\mathrm{w}$ ith epidermal growth factor (EGF) s tructural hom ology (107). Although E GFL6 h as be en detected at the m RNA level in numerous cancers, the protein has not be en de tected in carcinoma cells and little is understood regarding its in vivo function. In vitro, full-length recombinant E GFL6 ha s be en de monstrated to i nduce $m$ igration and angiogenesis in endothelial $\mathrm{c}$ ells th rough a ctivation of $\mathrm{t}$ he ex tracellular s ignal-related kinase $\mathrm{p}$ athway (107). T hese da ta s uggest that E GFL6 $\mathrm{m}$ ay $\mathrm{c}$ ontribute to va scularization of ne w a nd perhaps $\mathrm{m}$ alignant $\mathrm{t}$ issue. $\mathrm{H}$ owever, $\mathrm{i}$ ts $\mathrm{r}$ oles $\mathrm{i} \mathrm{n}$ bot $\mathrm{h}$ de velopment a nd $\mathrm{t}$ umorigenesis remain unclear.

One method of exploring the vast array of protein interactions and associations in a system such as the tumor vasculature is through bacteriophage (phage) display (40). A 
single phage library can contain up to $10^{9}$ unique peptide sequences, of fering a sizeable potential for selection of a peptide fragment of a natural ligand, such as EGFL6, which is thought to be specific to tumor va sculature (72). Previous selections have demonstrated the feasibility of pha ge-based 1 igand i dentification, m ost not ably i solating the $\mathrm{p}$ eptide RGD (57). The RGD motif was identified in 28 of 32 phage-displayed peptides selected for binding to $\alpha_{5} \beta_{1}$ integrin, and consequently de monstrated to have high a ffinity for a number of integrins, i ncluding $\alpha_{v} \beta_{3}(45,57)$. Use of pe ptide pha ge di splay to i dentify binding e pitopes, such as RGD, in vitro has s pawned investigation in to the ability of phage display to isolate tissue and tumor specific peptides in vivo (108). In vivo phage display ha s pr eviously i dentified $t$ umor va sculature-homing pe ptides, a nd $\mathrm{s}$ pecific tripeptide s equences have be en $m$ apped to the $v$ asculature of num erous human or gans (49). Additionally, our laboratory has developed a strategy for isolating not only tumor vasculature but also solid tumor-specific peptides (50). These works indicate that phage can localize specifically to tumors, and recovered phage can be used to identify receptorbinding peptide epitopes.

It w as hypothesized that in vivo phage di splay could be us ed to select pe ptides which mimic tu mor-associated 1 igands. T he pe ptides $\mathrm{w}$ ould $\mathrm{s}$ erve not onl y a s $\mathrm{t}$ umor imaging ve ctors but may also be us ed to help validate novel $t$ umor biomarkers. Phage displayed $\mathrm{p}$ eptides $\mathrm{w}$ ith hom ology t o a know $\mathrm{n}$ pr otein $\mathrm{c}$ ould he $\mathrm{lp}$ va lidate pot ential ligands i dentified b y genomic or transcriptomic s tudies, or e lucidate po ssible pr oteins underrepresented or absent from traditional proteomic analyses. To test this idea, a phage library was subjected to four rounds of in vivo selection in mice bearing human MDA- 
MB-435 $b$ reast cancer xenografts. $D$ isplayed $p$ eptides of ph ages $r$ ecovered from $t$ he tumors w ere an alyzed by the b asic local alignment s earch tool (BLAST). A lthough a number of peptides matched potential tumor related proteins, one peptide, with 9 of 14

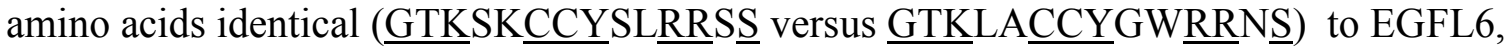
was chosen for further study due to its significant hom ology and the growing evidence that EGFL6 is a potential tumor vasculature ligand. The tumor cell line used for selection, as $w$ ell as s everal o ther can cer an $\mathrm{d} n$ on-cancer cell 1 ines, $w$ as $p$ robed for m RNA and protein e xpression of E GFL6. A dditionally, the $t$ umor $t$ argeting a nd S PECT i maging properties of the EGFL6 peptide were investigated in vivo. 


\section{Materials and Methods}

\section{Materials}

Materials for cell culture were purchased from Invitrogen (Carlsbad, CA). Unless otherwise specified, all reagents and materials were obtained from Sigma Chemical Co. (St. Louis, MO).

\section{Mouse Strains and Handling}

Four- to 6 -week-old s evere combined i mmunodeficient ( SCID) o utbred mic e (Taconic, Germantown, N Y) were maintained i n a pproved pa thogen-free in stitutional housing. Animal studies were conducted as outlined in the NIH Guidelines for the Care and Use of Laboratory Animals and the Policy and Procedures for Animal Research of the Harry S. Truman Veterans Memorial Hospital. MDA-MB-435 hum an br east cancer xenografts $\left(5 \times 10^{6}\right)$ were es tablished by subcutaneous injection into the flank of SCID mice. Mice were utilized when visual tu mors $\left(\sim 1-3 \mathrm{~mm}^{3}\right)$ formed after a pproximately 5 weeks.

\section{Phage Display Selection and Analysis}

In vivo phage di splay was pe rformed as de scribed pr eviously (50). Briefly, a phage 1 ibrary containing a pproximately $1 \times 10^{12}$ tetracycline transducing units of pha ge was i njected i nto S CID $\mathrm{m}$ ice $\mathrm{b}$ earing M DA-MB-435 hum an br east $\mathrm{c}$ ancer $\mathrm{x}$ enografts. Phages were allowed to circulate for $1 \mathrm{~h}$ and following perfusion with phosphate buffered 
saline (PBS), tumors were excised and frozen in liquid nitrogen. Tumors were manually homogenized a nd bou nd pha ges e luted b y i ncubation w ith $2.5 \%$ ( w:v) 3-[(3cholamidopropyl)dimethylammonio]-1-propanesulfonate ( CHAPS) s olution. R ecovered phages were used to infect $\log$ phase K91BK E. coli cells, amplified for $16 \mathrm{~h}$ in a $37^{\circ} \mathrm{C}$ incubator with shaking and purified by polyethylene glycol/sodium chloride precipitation (76). Purified phages were quantified and used for subsequent rounds of selection, for a total of four selection rounds. Following the final round of selection, individual phages were isolated and their relevant DNA was sequenced in order to ascertain the displayed foreign pe ptide of each phage. P eptide s equences w ere then qu eried us ing the B LAST search pr ogram $\mathrm{f}$ or $\mathrm{s}$ equence hom ology $\mathrm{t}$ o pr oteins $\mathrm{w}$ ith know $\mathrm{n}$ or $\mathrm{p}$ utative $\mathrm{c}$ ancer correlations (77).

\section{EGFL6 RT-PCR}

In or der to a ssay egfl6 mRNA ex pression, three human breast can cer cell lines, MDA-MB-435, MDA-MB-468, SK-BR-3, and a normal cell line HEK-293, were grown to $80 \%$ confluency in T75 flasks and their RNA was isolated using Trizol (Ambion, Life Technologies, Grand Island, NY). Total RNA was quantified by spectrophotometry and $500 \mathrm{ng}$ w as r everse t ranscribed to cD NA u sing SuperScript III R everse Transcriptase (200 uni ts $/ \mu \mathrm{L})$ and ol igodT pr imers $(2.5 \mu \mathrm{M})$ (Life T echnologies, G rand Island, N Y). The $\mathrm{s}$ ubsequent $\mathrm{c}$ DNA $\mathrm{w}$ as ut ilized $\mathrm{f}$ or $\mathrm{P} \mathrm{CR} \mathrm{r}$ eactions $\mathrm{w}$ ith egfl6 specific $\mathrm{p}$ rimers previously de monstrated to a mplify th e gene of in terest (104). $\mathrm{T}$ he primers [ (5'CGGGATCCCTGTGCTACGTCGCCCTGGAC- $\left.\quad 3^{\prime}\right) \quad$ and $\quad 5^{\prime}-$ CGGAATTCACTGGCGCAGGCGGTGATCTCCTT-3')] w ere di luted t o $10 \mu \mathrm{M}$ a nd 
added to $2 \mu \mathrm{L}$ of cDNA for the reaction. The cycling conditions were $98^{\circ} \mathrm{C}$ for $30 \mathrm{~s}$ for one c ycle, followed by $30 \mathrm{c}$ ycles of $98^{\circ} \mathrm{C}$ for $10 \mathrm{~s}, 60^{\circ} \mathrm{C}$ for $30 \mathrm{~s}$ and $72^{\circ} \mathrm{C}$ for $30 \mathrm{~s}$. Primers for b eta-actin w ere us ed a s a loading c ontrol. P CR products w ere $\mathrm{r}$ un on $1 \%$ agarose gels and visualized by ethidium bromide staining.

\section{Immunoassay}

Each cell line was analyzed by immunoassay for EGFL6 protein expression in the cell lysate and supernatant using a polyclonal anti-EGFL6 antibody (Prestige Antibodies, Sigma, St. Louis, MO). Cells were grown to $80 \%$ confluency, supernatant harvested and both cells and supernatant were incubated with Laemmli buffer ( $2 \% \mathrm{w}$ :v sodium dodecyl sulfate, $10 \%$ g lycerol, $60 \mathrm{~m} \mathrm{M}$ T ris, $0.01 \%$ br omophenol bl ue). P rotein c oncentrations were determined by Bio-Rad protein assay (Bio-Rad, Hercules, CA) and $500 \mu \mathrm{g}$ of total protein w as i ncubated with $\mathrm{N}$ uPAGE LDS s ample buf fer ( Life T echnologies, G rand Island, NY) at $80^{\circ} \mathrm{C}$ for $10 \mathrm{~min}$ and loaded onto NuPAGE Novex 4-12\% Bis-Tris gels. Samples w ere e lectrophoresed $\mathrm{f}$ or $90 \mathrm{~m}$ in a $\mathrm{t} 120 \mathrm{~m} \mathrm{~V}$ a nd transferred t o $0.2 \mu \mathrm{m}$ nitrocellulose membrane (Bio-Rad, Hercules, CA). Following transfer, membranes were blocked with 5\% non-fat dry milk. Blocked membranes were incubated with anti-EGFL6 antibody di luted 1:50 in Tris buffered s aline and 0.1\% Tween-20 (0.1\% TBST) for 10 min and va cuum aspirated by SNAP i.d. (Merck Millipore, Billerica, MA). Membranes were $\mathrm{w}$ ashed $\mathrm{t}$ hree $\mathrm{t}$ imes $\mathrm{w}$ ith $0.1 \% \mathrm{~T}$ BST a nd pol yclonal anti-rabbit hor seradish peroxidase-conjugated a ntibody di luted 1: 1000 in $0.1 \%$ T BST $w$ as incubated w ith the membrane for $10 \mathrm{~m}$ in. $\mathrm{V}$ acuum a spiration a nd washing were completed a s $\mathrm{w}$ ith $\mathrm{t}$ he primary antibody. $\mathrm{M}$ embranes $\mathrm{w}$ ere de veloped us ing $\mathrm{S}$ uperSignal $\mathrm{W}$ est Pico 
chemiluminescent substrate (ThermoFisher Scientific, Rockford, IL) and visualized using a VersaDoc Molecular Imager (Bio-Rad, Hercules, CA).

\section{Peptide Synthesis}

Synthesis of a ll peptides w as a ccomplished w ith an A dvanced Chem Tech 396 multiple peptide synthesizer using solid phase FMOC chemistry. Peptides were designed with an N-terminal GSG peptide spacer covalently linked at its N-terminus with biotin or 1,4,7,10-tetraazacyclododecane-1,4,7,10-tetraacetic aci d (DOTA) (Macrocyclic, I nc. Dallas, TX).

\section{Biotinylated Peptide Fluorescent Microscopy}

All c ell 1 ines $w$ ere g rown $\mathrm{t}$ o $80 \%$ c onfluencya nd fixed $w$ ith $4 \%$ paraformaldehyde. C ells w ere dr ied ont o $\mathrm{m}$ icroscope $\mathrm{s}$ lides ove rnight $\mathrm{f}$ ollowed b y rehydration with P BS. Slides $w$ ere bl ocked $w$ ith $5 \%$ BSA in P BS for $2 \mathrm{~h}$ at room temperature. Biotinylated EGFL6 peptide was diluted to $10 \mu \mathrm{M}$ in PBS and $100 \mu \mathrm{L}$ was added to each cell sample for incubation at room temperature for $1 \mathrm{~h}$. Slides were washed 3 times with $0.1 \%$ T BST and c ells w ere incubated w ith N eutravidin T exas R ed ( Life Technologies, R ockville, M D) di luted t o $5 \mu \mathrm{g} / \mathrm{mL}$ in $0.1 \% \mathrm{~T}$ BST f or $1 \mathrm{~h} \mathrm{a} \mathrm{t}$ room temperature. Washing was performed in the same manner and cells were visualized by an epifluorescent Nikon T1-SM inverted microscope (Nikon, Melville, NY). 


\section{DOTA-EGFL6 Radiolabeling and Purification}

DOTA-EGFL6 $\mathrm{w}$ as di luted t o $1 \mathrm{~m} \mathrm{~g} / \mathrm{mL}$ i $\mathrm{n} \mathrm{w}$ ater a nd i ncubated $\mathrm{w}$ ith $0.1 \mathrm{M}$ ammonium acet ate $(\mathrm{pH})$ and $18.5 \mathrm{MBq}$ of ${ }^{111} \mathrm{In}$ a $\mathrm{t} 80^{\circ} \mathrm{C}$ for $1 \mathrm{~h}$. Reactions w ere quenched by a ddition of $10 \mu \mathrm{M}$ EDTA. R adiolabeled pe ptide $\mathrm{w}$ as pur ified by reverse phase HPLC using a linear gradient of acetonitrile plus $0.1 \%$ trifluoroacetic acid from 5 $95 \%$ over $35 \mathrm{~min}$. A cetonitrile w as e vaporated by nitrogen gas flow, and pe ptide w as diluted to appropriate concentration using sterile PBS.

\section{${ }^{111}$ In-DOTA-EGFL6 Cell Binding}

MDA-MB-435, M DA-MB-468, S K-BR-3 and HEK-293 cells w ere d iluted to $2 \times 10^{6}$ cells $/ \mathrm{mL}$ in Dulbelco's modified eagle medium (DMEM) with $0.1 \mathrm{mg} / \mathrm{mL} \mathrm{BSA}$. ${ }^{111}$ In-DOTA-EGFL6 was diluted to $1 \times 10^{7} \mathrm{CPM} / \mathrm{mL}$ in DMEM plus $0.1 \%$ BSA and 100 $\mu \mathrm{L}$ of peptide was added to $200 \mu \mathrm{L}$ of cells and incubated at $37^{\circ} \mathrm{C}$ for $1 \mathrm{~h}$. Cells were washed three times with ice-cold PBS with $1 \%$ BSA and counted via gamma counter.

\section{${ }^{111}$ In-DOTA-EGFL6 Biodistribution and MicroSPECT/CT Imaging}

DOTA-EGFL6 peptide $\mathrm{w}$ as radiolabeled $\mathrm{w}$ ith ${ }^{111} \mathrm{In}$ a nd pur ified pe ptide $\mathrm{w}$ as prepared at $1.85 \mathrm{MBq} / \mathrm{mL}$ in sterile PBS. Three mice bearing MDA-MB-435 tumors were intravenously injected with ${ }^{111}$ In-DOTA-EGFL6 and sacrificed at $2 \mathrm{~h}$. Organs and tissues pertinent to tumor uptake and clearance were excised, weighed, and counted by gamma counter. $\mathrm{P}$ ercentage o f i njected $\mathrm{d}$ ose $\mathrm{p}$ er $\operatorname{gram}(\% \mathrm{ID} / \mathrm{g})$ o $\mathrm{ft}$ issue was $\mathrm{r}$ eported $\mathrm{t}$ o normalize uptake by tissue mass. 
Radiolabeled, purified ${ }^{111}$ In-DOTA-GSG-EGFL6 was diluted to $11.1 \mathrm{MBq}$ in 100 $\mu \mathrm{L}$ of sterile PBS. The peptide was injected intravenously in a mouse bearing an MDAMB-435 hum an br east $\mathrm{c}$ ancer $\mathrm{x}$ enograft. Following i njection, $\mathrm{r}$ adiolabeled pe ptide $\mathrm{w}$ as permitted to circulate for $2 \mathrm{~h}$, followed by euthanization by carbon dioxide. The treated mouse was imaged at the Harry S. Truman V eterans Memorial Hospital Biomolecular Imaging Center. Overnight (7 h) image acquisition was performed with a Siemens Inveon Micro-SPECT/CT (Siemens, Knoxville, TN) equipped with mouse whole body $1.0 \mathrm{~m} \mathrm{~m}$ collimators. Data were processed with Inveon Research W orkplace processing s oftware and $\mathrm{f}$ an be am ( Feldkamp) $\mathrm{f}$ iltered $\mathrm{b}$ ack pr ojection a lgorithms $\mathrm{w}$ ere us ed for reconstruction of the CT tomographic image. 


\section{Results}

\section{Phage Display Selection and Analysis}

Completion of four rounds of in vivo phage display selection resulted in a s ubpopulation of pr esumed hum an br east $t$ umor-avid pha ge c lones. D NA s equence corresponding to the foreign di splayed pe ptide of $269 \mathrm{t}$ umor a vid pha ges w as obt ained and analyzed by the BLAST a lgorithm for hom ology to hum an cancer-related p roteins (77). For each peptide sequence, the top 10 matching proteins were evaluated for percent homology a nd pr evious i dentification a s a cancer-related o $\mathrm{r} p$ utative can cer-related protein. O ne di splayed peptide, from the pha ge c lone 3 -G03, r evealed 64\% i dentical homology to a protein termed EGFL6 (Figure 3.1). The match returned a s core of 24.0 bits c onsisting of $9 / 14$ pos itive i dentities and $0 \mathrm{~g}$ aps. The $\mathrm{m}$ atch returned a e xpected value of 4.9, i ndicating $\mathrm{t}$ hat $\mathrm{r}$ andom assignment of a mino a cids $\mathrm{w}$ ould onl $\mathrm{y} r$ eturn approximately 5 random $\mathrm{m}$ atches i $\mathrm{n}$ the e ntire pr otein $\mathrm{d}$ atabase. $\mathrm{N}$ o ot her s equence returned a cancer-related protein and had sequence similarity greater than $50 \%$.

\section{EGFL6 RT-PCR and Immunoassay}

Due to the significant homology of the phage displayed peptide to EGFL6, it was inferred that the MDA-MB-435 cell line used for xenograft establishment for the in vivo phage di splay s election expressed EGFL6. In or der to c onfirm egfl6 transcription, R TPCR was performed. Additionally, two more breast cancer cell lines, MDA-MB-468 and SK-BR-3, and a non-cancer cell line, HEK-293, were also assessed. PCR products from 


\section{$\begin{array}{llll}40 & 50 & 60 & 70\end{array}$ \\ I I I I \\ EGFL6 PGVCHYGTKLACCYGWRRNSKGVCEATCEPGCK 3-G03 GTKSKCCYSLRRSS}

Figure 3.1 The in vivo selected peptide $3-\mathrm{G} 03$ was a ligned with E GFL6 for s equence comparison. A portion of the full length EGFL6 protein corresponding to the homologous selected $\mathrm{p}$ eptide i s di splayed, $\mathrm{w}$ ith $\mathrm{t}$ he ha shed numbers $r$ epresenting the a mino a cid position from the $\mathrm{N}$-terminus. Identical matches are highlighted. 
EGFL6 s pecific primers first u sed to id entify the mR NA w ere visualized by ethidium bromide stain in agarose gel (104). The results demonstrated a band corresponding to the expected fragment size of 801 nuc leotides in the lane corresponding to MDA-MB-435 cDNA and a fainter band in the lane containing cDNA from MDA-MB-468 cells (Figure 3.2). No band was identified in the SK-BR-3 and HEK-293 lanes. Loading controls were accomplished using beta actin-specific primers producing a 315 nucleotide band, which was found in similar intensity in all cell lines analyzed.

Identification of egfl6 at the m RNA l evel provided i mpetus to a nalyze protein expression of each cell 1 ine. S ince EGFL6 is a s ecreted protein, both the cells and the cultured supernatant were used for immunoblotting (Figure 3.3). A band was identified in the s upernatant of M DA-MB-435 cel ls $t$ hat co rresponded t o $t$ he ex pected $m$ olecular weight of EGFL6, 66 kDa. No band was detected in the supernatant of all o ther cell lines, nor the cell pellet of any cells examined, including MDA-MB-435.

\section{Biotinylated EGFL6 Peptide Fluorescent Microscopy}

In order to confirm EGFL6 peptide affinity for MDA-MB-435 cells, the peptide sequence of EGFL6 ( GTKWACCYGWRNSS) di rectly corresponding to the i dentified phage displayed peptide was synthesized and conjugated at the N-terminus with biotin for detection by a fluorophore labeled streptavidin. Peptide binding was analyzed in the same four c ell 1 ines, M DA-MB-435, M DA-MB-468, S K-BR-3 a nd HEK-293, us ed for R TPCR and immunoassay experiments. The results demonstrated the peptide bound strongly to MDA-MB-435 and MDA-MB-468 cells, while showing less binding to SK-BR-3 cells and no binding to HEK-293 cells (Figure 3.4). 


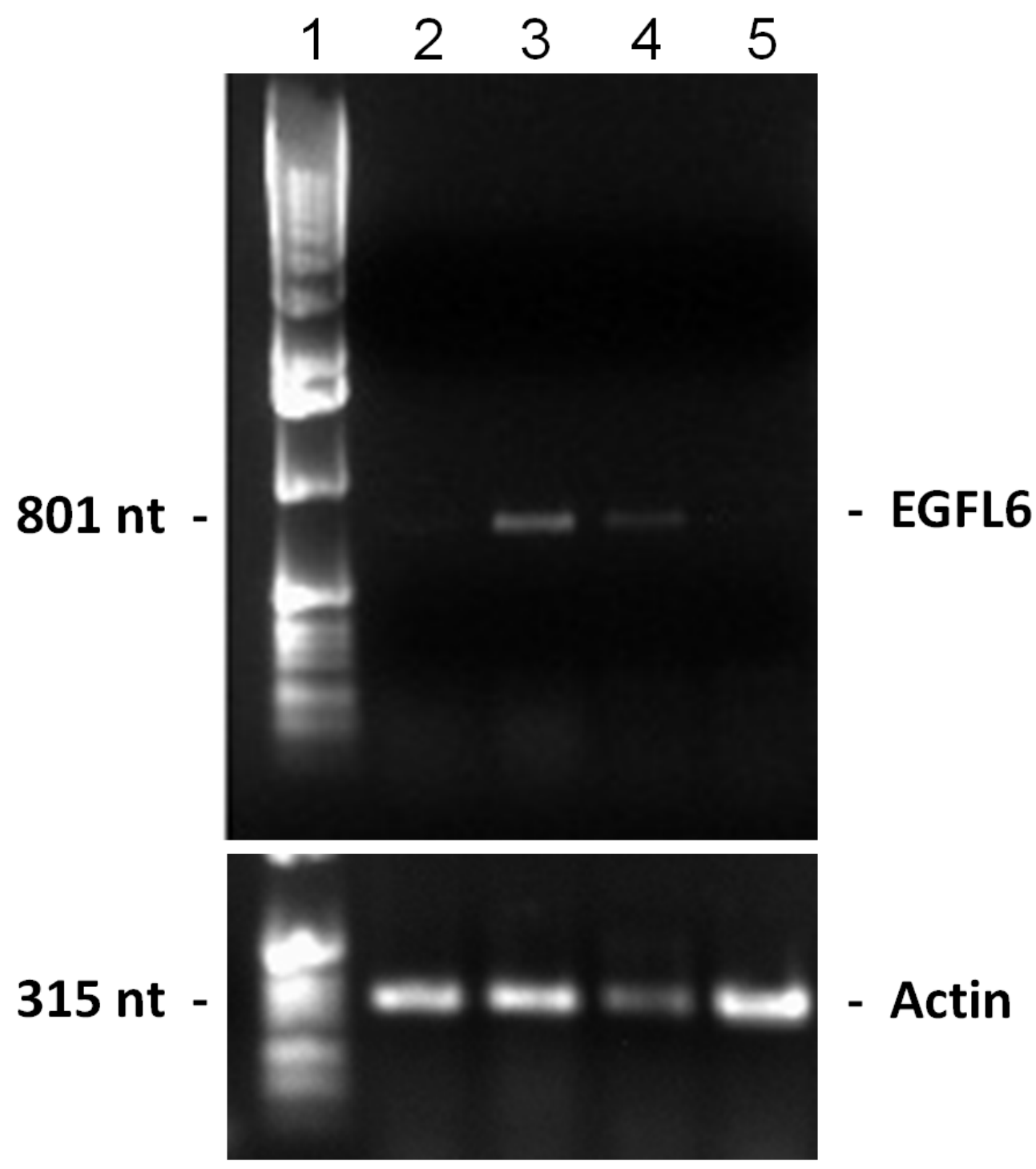

\section{Figure 3.2}

Isolated RNA from 3 human breast cancer cell lines and one human kidney cell line was reverse transcribed and amplified using EGFL6-specific primers. Bands of the ex pected nucleotide 1 ength $w$ ere d etected i n M DA-MB-435 and M DA-MB-468 samples. Additionally, a primer for $\beta$-Actin $\mathrm{w}$ as us ed a s a 1 oading $\mathrm{c}$ ontrol. $\mathrm{N}$ umbered 1 anes represent the following: 1) Ladder, 2) SK-BR-3, 3) MDA-MB-435, 4) MDA-MB-468, 5) HEK-293. 


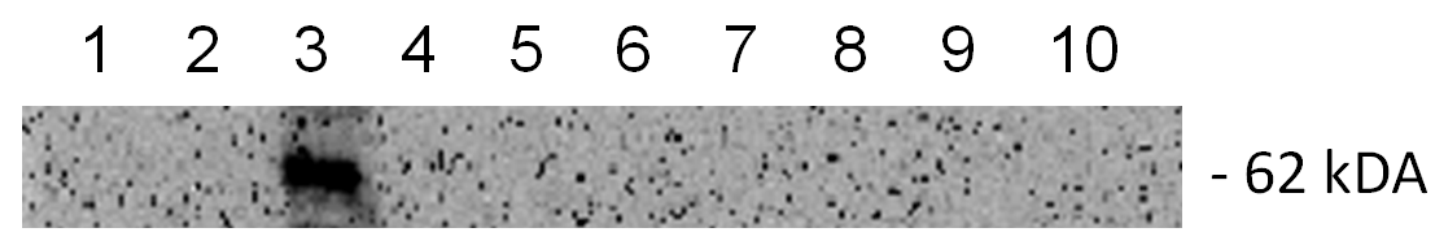

Figure 3.3 Total protein from cell lysates and cultured medium from corresponding cells were run on S DS-PAGE ge 1s, $t$ ransferred t o ni trocellulose, a nd E GFL6 de tected b y immunoblot. One band was detected at the expected molecular weight for EGFL6 in the cultured supernatant of MDA-MB-435 cells. Numbered lanes represent the following: 1) Ladder, 2 ) MDA-MB-435 cell 1 ysate, 3 ) MDA-MB-435 supernatant, 4) MDA-MB-468 cell lysate, 5) MDA-MB-468 supernatant, SK-BR-3 cell lysate, 6) SK-BR-3 supernatant, 7) HEK-293 cell lysate, 8) HEK-293 supernatant, 9) ladder, 10) loading buffer. 

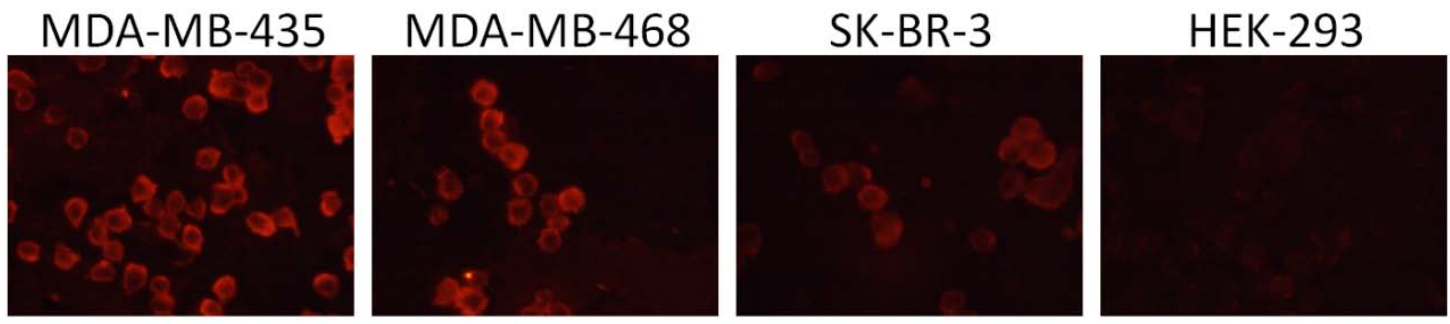

Figure 3.4 Human b reast can cer an d k idney cells $w$ ere i ncubated $w$ ith b iotinylated peptides and vi sualized b y fluorescent Neutravidin. F luorescent s ignal was d etected in MDA-MB-435 and MDA-MB-468 cells, but not in SK-BR-3 or HEK-293 cells. 


\section{${ }^{111}$ In-DOTA-EGFL6 Cell Binding}

After confirmation of $\mathrm{c}$ ell bi nding w ith bi otinylated pe ptide, $t$ he pe ptide $\mathrm{w}$ as conjugated to the macrocyclic chelator D OTA for radiolabeled peptide binding a ssays. Radiolabeled peptide was examined for its ability to bind MDA-MB-435, MDA-MB-468, SK-BR-3 and HEK-293 cells. Peptide binding was determined to be $12.3 \pm 1.0 \%$ (12284 $\mathrm{CPM})$ of total peptide added for MDA-MB-435, 10.5\% $2.7 \%$ (10508 CPM) for MDA-

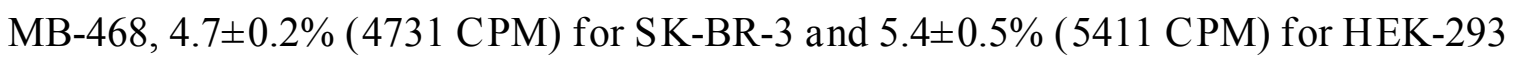
cells (Figure 3.5). The binding of ${ }^{111}$ In-DOTA-EGFL6 was significantly higher to MDAMB-435 than SK-BR-3 $(P<0.001)$ and HEK-293 $(P<0.001)$ cells. Peptide binding was similar between MDA-MB-435 and MDA-468 cells and binding to MDA-MB-468 cells was also significantly higher $(P<0.05)$ than binding to SK-BR-3 or HEK-293 cells.

\section{${ }^{111}$ In-DOTA-EGFL6 Biodistribution}

${ }^{111}$ In-DOTA-EGFL6 bi nding to M DA-MB-435 cells in vitro warranted in vivo analysis of the tumor targeting and non-target organ accumulation of EGFL6. In order to ascertain a preliminary understanding of the biodistribution, the pharmacokinetics of the peptide $\mathrm{w}$ ere an alyzed at $2 \mathrm{~h}$ p ost-injection ( Figure 3.6). $\mathrm{T}$ umor uptake of $\mathrm{t}$ he radiolabeled pe ptide was $0.36 \pm 0.08 \% \mathrm{ID} / \mathrm{g}$, while bl ood $\mathrm{r}$ etention of the pe ptide $\mathrm{w}$ as $1.30 \pm 0.51 \% \mathrm{ID} / \mathrm{g}$. N on-target or gan a ccumulation was be low $1.0 \% \mathrm{ID} / \mathrm{g}$ for all or gans measured, except for the kidneys. Kidney retention of the peptide was $28.61 \pm 4.24 \% \mathrm{ID} / \mathrm{g}$. The tumor to blood ratio of the peptide was 0.27 , while the tumor to muscle ratio was 2.7 . 


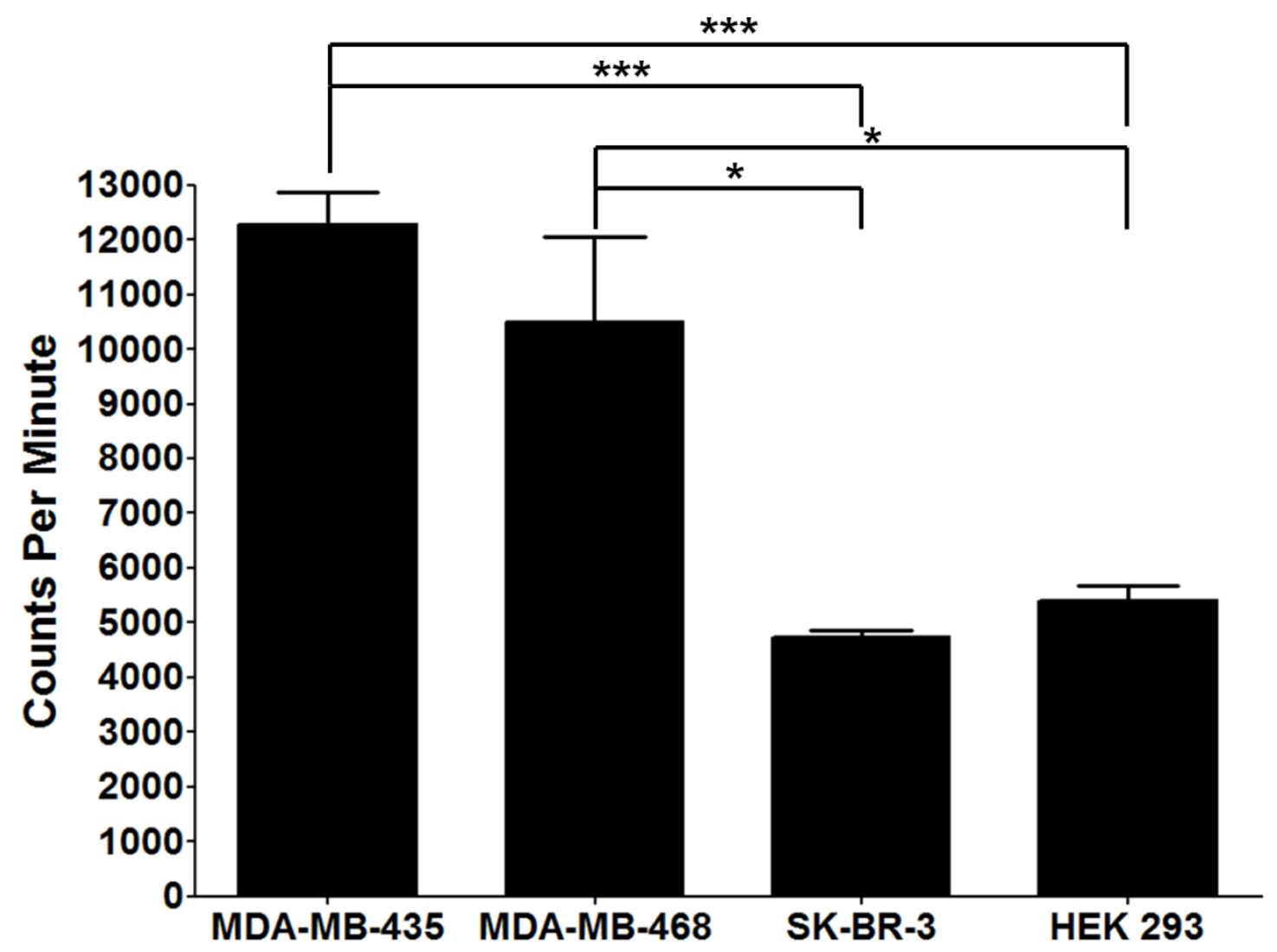

Figure $3.5{ }^{111}$ In-DOTA-EGFL6 peptide w as incubated with cell lines and binding w as quantified. The peptide bound to MDA-MB-435 and MDA-MB-468 cells significantly higher than SK-BR-3 and HEK-293 cells. Error bars represent the standard deviation of 4 samples. *- $P<0.05 * * *-P<0.001$ 


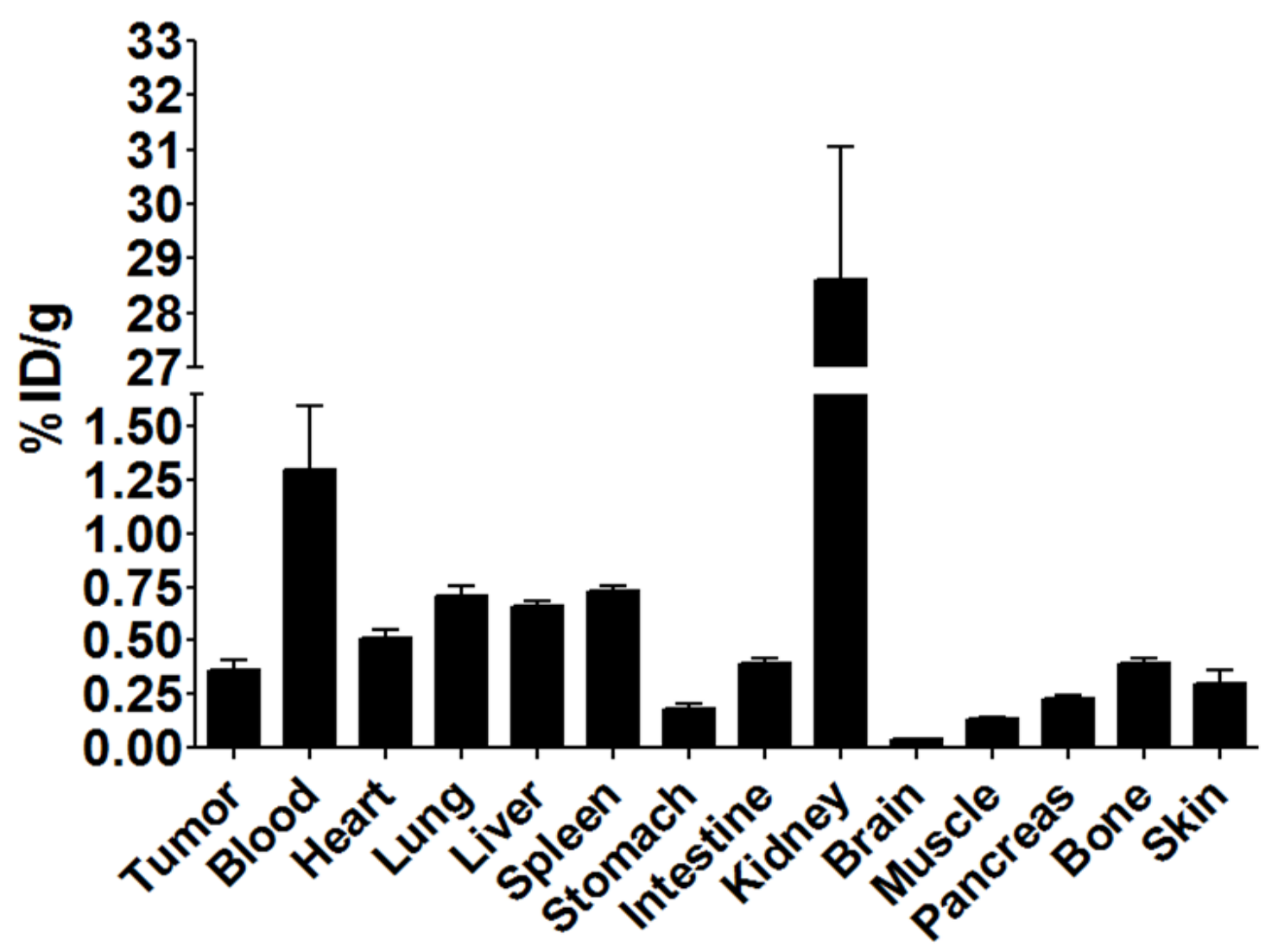

Figure 3.6 ${ }^{111}$ In-DOTA-EGFL6 $\mathrm{w}$ as i njected into $\mathrm{m}$ ice b earing M DA-MB-435 hum an breast $\mathrm{c}$ ancer $\mathrm{x}$ enografts. T issue bi odistribution was a nalyzed $2 \mathrm{~h}$ pos $\mathrm{t}$ i njection. $\mathrm{B}$ ars represent the mean of $n=4$ and error bars signify the standard deviation. $\% \mathrm{ID} / \mathrm{g}-$ percent injected dose/gram. 


\section{${ }^{111}$ In-DOTA-GSG-EGFL6 SPECT/CT Imaging}

In a ddition to b iodistribution, tu mor ima ging capabilities of ${ }^{111}$ In-DOTA-GSGEGFL6 were explored. SPECT/CT images were collected at $2 \mathrm{~h}$ post-injection in order to correspond $w$ ith $t$ he bi odistribution da ta (Figure 3.7). Imaging $r$ evealed 1 ow $t$ umor uptake, however, the interface between the xenograft and the muscle of the mouse had a strikingly high $\mathrm{c}$ oncentration of $\mathrm{r}$ adiolabel. $\mathrm{K}$ idney retention $\mathrm{w}$ as also visible i $\mathrm{n} \mathrm{t}$ he mouse, in addition to apparent cranio-facial, esophageal, and stomach intake, consistent with i ncidental i ngestion of $t$ he $r$ adiolabeled pe ptide $f$ ollowing or al $\mathrm{c}$ leaning of $\mathrm{t}$ he injection site. 

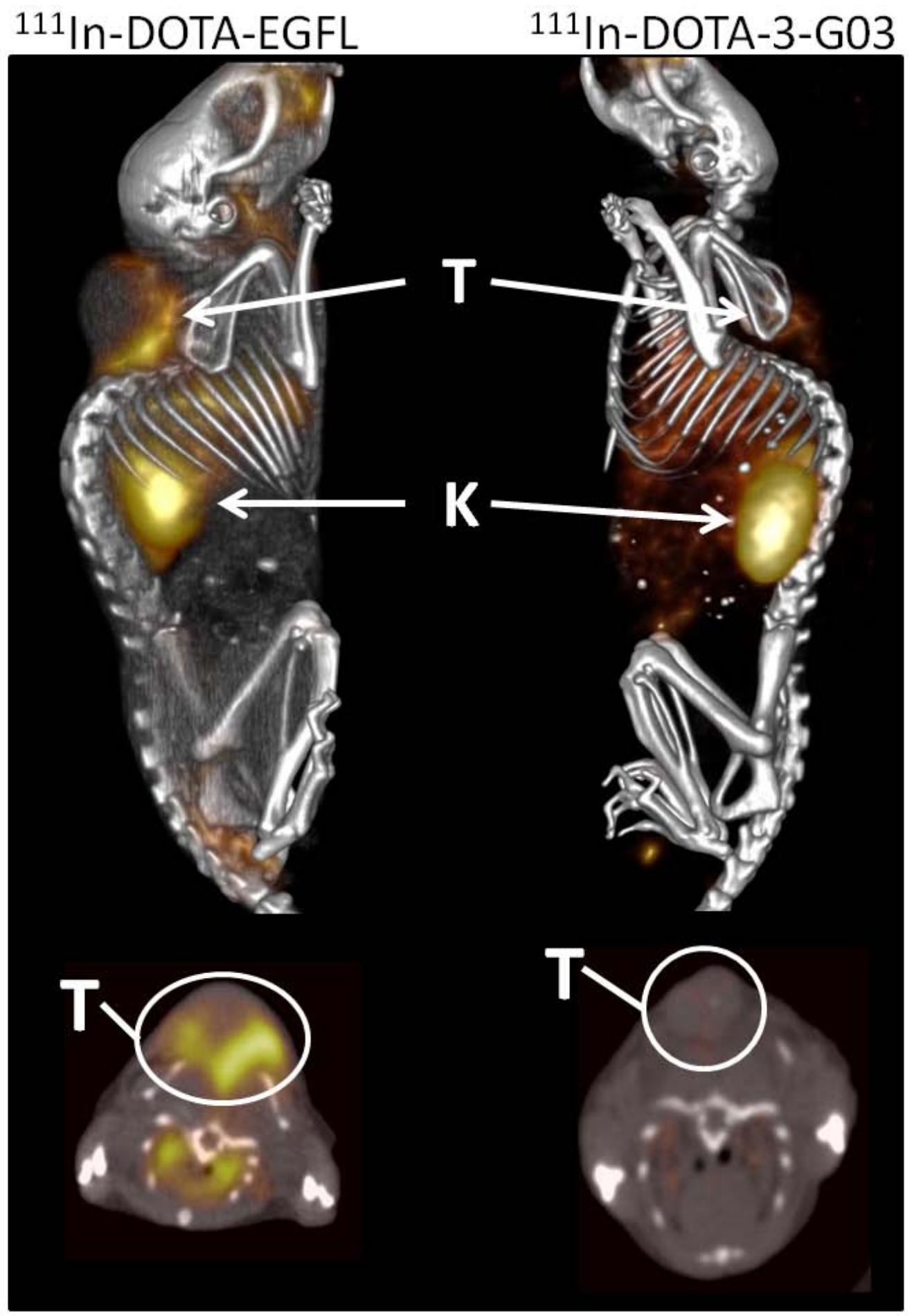
Figure $3.7{ }^{111}$ In-DOTA-EGFL6 a nd ${ }^{111}$ In-DOTA-3-G03 w ere i njected into MDA-MB435 human breast carcinoma tumor bearing mice. SPECT/CT imaging was acquired $2 \mathrm{~h}$ post-injection. $\mathrm{U}$ ptake of ${ }^{111} \mathrm{In}$-DOTA-EGFL6 is $\mathrm{c}$ onsistent $\mathrm{w}$ ith tu mor $\mathrm{v}$ asculature accumulation. Sequence specificity of the EGFL6 peptide was confirmed by using the 3G03 peptide, which differs by only 5 a mino acids. 3-G03 did not have a tumor uptake pattern s imilar t o E GFL6, but di d s how s imilar ki dney uptake, which i s t ypical of radiolabeled peptides. 


\section{Discussion}

Angiogenesis in cancer is a key component of tumor progression and, as such, has received $\mathrm{m}$ uch at tention i $\mathrm{b}$ oth $\mathrm{b}$ asic an $\mathrm{d} t$ ranslational $\mathrm{r}$ esearch. $\mathrm{C}$ linically-approved drugs including bevacizumab (Avastin $\AA$; Genentech) and sunitinib (Sutent ${ }^{\circledR}$; S ugen) in

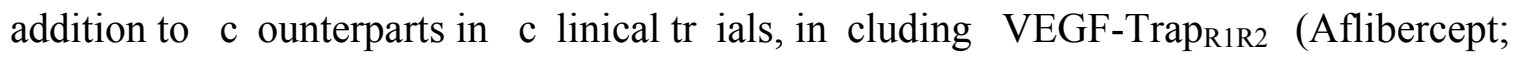
Regeneron Inc.) an d vendatanib (Caprelsa; A straZeneca), i llustrate the m ajor em phasis placed on $\mathrm{p}$ reventing tumor angiogenesis (109-112). Unfortunately, response to c urrent anti-angiogenic $t$ herapy i s g enerally $\mathrm{t}$ ransient, an $\mathrm{d} r$ elapse i s co mmon (113). O ne hypothesis for the eventual ineffectiveness of anti-angiogenic therapy is circumvention of therapeutic bl ockade b y upr egulation of complementary growth factors and r eceptors, such as EGFR and fibroblast Bv8 $(114,115)$. Identification of the potential ligands that promote $t$ umor an giogenesis i s n ecessary t o help o vercome $r$ esistance $t$ o cu rrent therapies. Although the list of tumor-associated ligands is extensive, it is unlikely to be complete (95).

Proteins involved in tumorigenesis can be identified at three levels: the genome, transcriptome and proteome. While high throughput DNA, RNA and protein expression interrogation $\mathrm{t}$ echniques pr ovide uni que a dvantages i ncluding 1 arge s ample s ize, quantification a nd br eadth of r esults, e ach b y i tself is i ncomplete. G enetic differences may not be transcribed, transcriptional differences may not be translated, and proteomic differences may be too small to be distinguished. Additionally, ex vivo analysis c annot directly in vestigate $\mathrm{p}$ hysiological lo cation or $\mathrm{f}$ unction. In order $\mathrm{t} \mathrm{o} \mathrm{s}$ upplement $\mathrm{t}$ hese 
techniques, a m ethod, such a s in vivo phage di splay, $\mathrm{c}$ an be us ed to e xplore protein interactions in a ph ysiological e nvironment. In vivo phage di splay $\mathrm{h}$ as be en ut ilized previously to map vascular signatures and identify novel tumor-associated proteins, such as pr oteome a ctivator c omplex 28 a nd pl ectin-1 $(49,58,116)$. In vivo phage di splay provides t wo ke y supplementary $f$ eatures $t$ o c urrent hi ght hroughput s creening techniques: the ability to identify proteins that are expressed at low levels and not likely to be recognized by proteomic procedures, and the potential to identify targets that are biologically accessible for targeted imaging and therapy. Therefore, it $\mathrm{w}$ as hypothesized that an in vivo phage di splay selection c ould id entify tu mor a ssociated lig ands b y isolation of peptides with a similar sequence and function.

The in vivo selection e nabled id entification of $\mathrm{p}$ eptides $\mathrm{w}$ ith tu mor ima ging capabilities in a ddition to p roviding a $\mathrm{n}$ oppo rtunity to e xplore $\mathrm{w}$ hether pe ptides $\mathrm{w}$ ere similar to sequences of known or putative cancer proteins. Peptides corresponding to 267 phage $\mathrm{cl}$ ones $\mathrm{r}$ ecovered $\mathrm{f}$ rom $\mathrm{h}$ uman $\mathrm{b}$ reast $\mathrm{c}$ ancer $\mathrm{x}$ enografts $\mathrm{w}$ ere a nalyzed $\mathrm{b}$ y $\mathrm{t}$ he BLAST a lgorithm for homology to know $\mathrm{n}$ cancer-related proteins. Since the sequences being analyzed were relatively short (15 amino acids), it was necessary to arbitrarily limit the scope of what was considered a match to greater than $50 \%$ hom ology. This greatly reduced the number of artificial hits that would be generated by random chance. Of the 267 pe ptides a nalyzed, onl y on e, 3 -G03, f it th e c riteria s pecified. 3 -G03

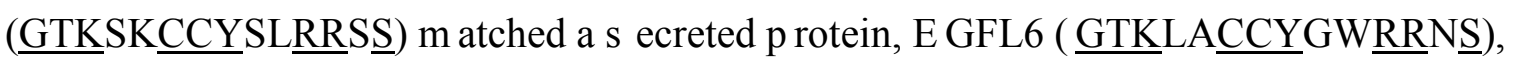
with $64 \%$ hom ology and $r$ eturned a s core of 24 bi ts, p rimarily du e to the num ber of identical matches (9) and the absence of gaps needed to make the identical pairs. It was interesting to note that the $9 \mathrm{i}$ dentical pairs consisted of $2 \mathrm{t}$ ripeptide sequences, and an 
additional 4 pe ptide s equence $\mathrm{w}$ ith one $\mathrm{m}$ ismatch. $\mathrm{T}$ his i $\mathrm{s} \mathrm{c}$ onsistent $\mathrm{w}$ ith pr evious selections $t$ hat $h$ ave $i$ dentified $t$ hree am ino acid $s$ equences capable o $\mathrm{fm}$ ediating interaction between a ligand and a receptor, as is the case of RGD and several integrins (57). Furthermore, tripeptide motifs have be en de monstrated to target phage to specific organs in vivo, including the tumor vasculature (49). The high homology between 3-G03 and EGFL6, in addition to the potential tumor vasculature promoting properties of the protein, led to further investigation into EGFL6 expression and peptide characterization.

Because a pe ptide with hom ology t o E GFL6 was i dentified b y the in vivo selection, it was as sumed that the xenografted breast cancer cell line expressed EGFL6. For confirmation, RT-PCR was used to analyze egfl6 transcription in three breast cancer cell lines and a control cell line. The results confirmed that egfl6 was expressed in MDAMB-435 c ells, in a ddition to M DA-MB-468 c ells, a lthough at a pparently lower levels. This result was consistent with identification of egfl6 expression in biopsy samples from ovarian and breast cancer, as well as meningioma $(100,102,106)$.

While eglf6 mRNA has been identified, EGFL6 protein has not been confirmed in cultured $\mathrm{c}$ arcinomas. In or der $\mathrm{t} \mathrm{o}$ ve rify $\mathrm{t}$ he egfl6 transcript was $\mathrm{t}$ ranslated, an immunoassay probing EGFL6 expression w as performed. EGFL6 is a secreted protein; therefore immunoassay was performed on both the cultured supernatant and cell pellet of all cell lines previously analyzed. Interestingly, EGFL6 protein was only identified in the supernatant of MDA-MB-435 c ells and not in MDA-MB-468 c ells. Lack of de tectable protein in MDA-MB-468 cells could have resulted from the protein concentration being undetectable by immunoassay, which is feasible due to the apparent diminished amount of m RNA d etected b y RT-PCR. A lso E GFL6 t ranslation in M DA-MB-468 c ells may 
have be en disrupted, as protein production in cancer cells has been demonstrated to be aberrant $(117,118)$. A dditionally, the $\mathrm{p}$ rotein $\mathrm{m}$ ay be de graded $\mathrm{r}$ apidly under in vitro conditions by the cells. Detection of EGFL6 protein expression in cultured MDA-MB435 cells confirmed the assumption that EGFL6 was expressed by the cell line used in the in vivo selection a nd provided $m$ otivation $t$ o f urther i nvestigate the $\mathrm{p}$ roperties of the EGFL6 peptide.

Although E GFL6 pr otein e xpression w as de monstrated b y i mmunoblot, $t$ he affinity and specificity of the corresponding EGFL6 peptide for human breast carcinomas needed to be assessed. The exact peptide sequence for EGFL6 corresponding to the phage displayed homologue was selected for analysis. This approach was chosen to maximize the pos sibility that the properties of the pe ptide w ere m ediated by the na tural E GFL6 sequence, and not selected by phage display. EGFL6 peptide was chemically synthesized with a covalently linked biotin to determine in vitro peptide specificity for the cell lines previously analyzed. Fluorescence microscopy revealed strong binding to MDA-MB-435 and MDA-MB-468 hum an breast cancer cells. Binding was undetectable to SK-BR-3, a third hum an breast cancer c ell line, and HEK-293 hum an ki dney cells. Peptide affinity for the carcinomas corresponded with cell lines that expressed egfl6 mRNA, even though the protein expression would suggest binding in only MDA-MB-435 cells. The receptor for EGFL6 is not known; therefore it is impossible to predict how the peptide or protein may bind to c ells. A correlation be tween peptide binding and egfl6 mRNA expression suggests that pe ptide u ptake $\mathrm{m}$ ay predict cellular ex pression o $\mathrm{ft}$ he egfl6 transcript. Obviously a short peptide sequence cannot fully mimic a full-length protein, which may 
contain several domains, post-translational modification sites and tertiary structure (104, 107).

Identification of a peptide that bound to human breast carcinoma cells expressing EGFL6 of fered the pot ential that the E GFL6 pe ptide c ould be us ed in vivo to d etect tumorigenesis in $\mathrm{x}$ enografts e xpressing th e $\mathrm{p}$ otential tu mor $\mathrm{v}$ asculature 1 igand. $\mathrm{T} \mathrm{o}$ evaluate $t$ he bi odistribution a nd i maging pr operties of $t$ he E GFL6 $p$ eptide, i $t w$ as necessary to conjugate the pe ptide to a $\mathrm{r}$ adiometal $\mathrm{c}$ helator. $\mathrm{B}$ ifunctional ma crocyclic DOTA $w$ as chosen due to its stable chelation with a number of radiometals, including indium-111, and well understood in vivo properties $(47,53,73)$. Prior to in vivo studies, retained specificity and affinity of the radiolabeled peptide was monitored by in vitro cell binding. ${ }^{111}$ In-DOTA-EGFL6 bound t o M DA-MB-435 a nd M DA-MB-468 c ells significantly higher than SK-BR-3 or HEK-293 cells, confirming retention of the breast cancer targeting properties of the peptide.

Radiolabeled, purified ${ }^{111}$ In-DOTA-EGFL6 was injected into mice bearing MDAMB-435 hum an breast cancer x enografts for biodistribution studies. Surprisingly, tumor uptake w as low at $0.36 \pm 0.08 \% \mathrm{ID} / \mathrm{g}$. The tumor to blood ratio w as a lso s uboptimal at 0.27 , but a $t$ umor $t$ o muscle $r$ atio of $2.7 \mathrm{i}$ ndicated s pecificity $f$ or the $t$ umor. A corresponding S PECT/CT ima ge w as acquired for further i nsight i nto the 1 ow t umor uptake. Image analysis correlated with the results of the bi odistribution. A lthough the solid tumor lacked significant uptake of ${ }^{111}$ In-DOTA-EGFL6, there appeared to be a high concentration a $\mathrm{t} t$ he $\mathrm{i}$ nterface of $\mathrm{t}$ he $\mathrm{t}$ umor a nd $\mathrm{t}$ he $\mathrm{s}$ ite of xenograft $\mathrm{f}$ ormation, presumably a s ight of hi gh ne ovascularization (119). T he S PECT/CT i mage was consistent $\mathrm{w}$ ith ot her $\mathrm{v}$ asculature-targeted $\mathrm{i}$ maging agents, $\mathrm{s}$ uch as radiolabeled R GD 
peptide (120). Absence of solid tumor-retention could be the result of peptide binding to its target at the novel vasculature and not permitting further diffusion into the tumor (56). Another reason for low tumor uptake might be differential expression of the receptor for EGFL6 in vitro and in vivo. In vivo expression of the receptor may be limited to cells near the site of neovascularization, thus limiting uptake to the interface of tumor and normal endothelial c ells (56). Previous w ork ha d de monstrated the pha ge s elected pe ptide, 3 G03, bound to MDA-MB-435 cells in vitro, and its sequence similarity to EGFL6 made ${ }^{111}$ In-DOTA-3-G03 a unique control to de termine whether the precise EGFL6 sequence was necessary for its in vivo imaging properties. While a very slight tumor uptake was observed $f$ or ${ }^{111}$ In-DOTA-3-G03, the di stinct va sculature-like bi nding observed $w$ ith ${ }^{111}$ In-DOTA-EGFL6 w as not present in the ${ }^{111}$ In-DOTA-3-G03 i mages. Kidney uptake, which is not sequence specific and instead a result of filtration of low molecular weight peptides, w as present for both pe ptides. S PECT/CT imaging revealed that E GFL6 w as targeted to the tumor-epithelial interface of human breast carcinoma x enografts, and the binding was specific to the EGFL6 peptide sequence. 


\section{Conclusion}

An in vivo phage display selection $\mathrm{r}$ esulted in the id entification of a pot ential tumor vasculature ligand, EGFL6. Additionally, a peptide with homology to EGFL6 was radiolabeled $w$ ith ${ }^{111}$ In a nd us ed to i mage t umor va sculature b y S PECT/CT. This da ta presents evidence that EGFL6 should be further investigated for its roles in tumorigenesis and as a possible imaging agent. 


\section{Acknowledgments}

The a uthors w ould 1 ike to acknowledge the c ontributions of Jessica N ewton-Northup, Marie T. Dickerson and the VA Biomolecular Imaging Core. This material is based upon work supported (or supported in part) by the Department of Veterans Affairs, Veterans Health A dministration, $\mathrm{O}$ ffice of $\mathrm{R}$ esearch and D evelopment, Biomedical L aboratory Research and Development, Clinical S ciences R esearch and Development including the Cooperative $\mathrm{S}$ tudies $\mathrm{P}$ rogram, $\mathrm{R}$ ehabilitation $\mathrm{R}$ esearch and Development $\mathrm{S}$ ervice, and Health Services Research and Development through a VA Merit Award (I01BX000964). The w ork i s a lso s upported b y a n N IH R 21 grant (1R21CA179069-01). Additional support provided by an NIBIB Training Grant NIBIB 5 T32 EB004822. 


\section{CHAPTER 4}

Development of a Peptide by Phage Display for SPECT Imaging of

Resistance-Susceptible Breast Cancer 


\section{Introduction}

The ability to detect malignant tissue non-invasively remains an important factor in diagnosing and treating carcinomas, including breast cancer. Traditionally, methods of diagnosis, $\mathrm{s}$ uch a s m ammography a nd ${ }^{18} \mathrm{~F}$-fluorodeoxyglucose pos itron e mission tomography, are $\mathrm{u}$ sed to i dentify ar eas of m alignancy. O ther $\mathrm{t}$ argeted $\mathrm{i}$ maging a gents, including $\mathrm{r}$ adiolabeled peptides $\mathrm{f}$ or $\mathrm{s}$ ingle $\mathrm{ph}$ oton e mission $\mathrm{c}$ omputed $\mathrm{t}$ omography (SPECT/CT), ha ve be en i ncorporated i n di agnostic pr ocedures t o not onl y p recisely pinpoint tumors, but also provide biologically relevant information about the malignancy non-invasively (32). Additionally, molecular characterization of the tumor often dictates the co urse of treatment. For ex ample, b reast can cers that ex press the es trogen receptor and the $r$ eceptor $t$ yrosine ki nase E RBB2 a re of ten $t$ reated $w$ ith $t$ he e strogen receptor antagonist $t$ amoxifen a nd a nti-ERBB2 a ntibody $t$ rastuzumab i $\mathrm{n} c$ ombination $\mathrm{w}$ ith a chemotherapeutic a gent $(121,122)$. D espite $t$ he s uccess a ccomplished us ing $t$ hese treatment $\mathrm{s}$ trategies, a major o bstacle is $\mathrm{t}$ he o ccurrence o $\mathrm{r}$ esistance to $\mathrm{t}$ he $\mathrm{t}$ argeted therapies, with $30 \%$ de veloping tamoxifen resistance, and greater than $50 \%$ de veloping trastuzumab $\mathrm{r}$ esistance $(123,124)$. A ta rgeting agent $\mathrm{w}$ ith the a bility $\mathrm{t}$ o $\mathrm{d}$ istinguish cancers $\mathrm{p}$ rone t $\mathrm{o}$ develop $\mathrm{r}$ esistance $\mathrm{w}$ ould greatly aid i $\mathrm{n} t$ he $\mathrm{d}$ irection o $\mathrm{ft}$ reatment strategies. 
Currently, there is no predictive diagnostic agent to as sess resistance to targeted therapies. In o rder t o develop an i maging agent cap able of d etecting carcinomas susceptible to therapeutics such as tamoxifen and trastuzumab, a proper animal model of breast cancer expressing the es trogen $r$ eceptor and ERBB2 that can be investigated in vivo and a ccurately mimicked in vitro is $n$ eeded. A b reast can cer cell 1 ine that forms reliable tumors i $\mathrm{n}$ a $\mathrm{m}$ ouse, e xpresses bot $\mathrm{h} t$ he e strogen $\mathrm{r}$ eceptor a nd E RBB2 a t physiologically relevant levels, and ha s be en shown to de velop resistance to therapies such as tamoxifen and trastuzumab could potentially serve as a t emplate for resistancesusceptible breast $\mathrm{c}$ ancer. $\mathrm{W}$ hen ch oosing an a pplicable cel 11 ine for $\mathrm{t}$ argeted therapy resistance, the most often used human breast cancer cell lines that form tumors in mice can be surveyed for estrogen receptor and ERBB2 status. It is well established that T47D and M CF7 $\mathrm{c}$ ell 1 ines, w hich a re estrogen $\mathrm{r}$ eceptor pos itive, $\mathrm{d}$ o not express ERBB2 $(125,126)$. Likewise, S K-BR-3 and MDA-MB-453 c ells ove r-express E RBB2 but lack detectable estrogen receptor (126). However, BT-474 human breast cancer cells are es trogen-dependant, ove r-express E RBB2 and f orm t umors i n m ice $(127,128)$. Although e strogen de pendant, B T-474 t umors a re na turally $r$ esistant t o $t$ amoxifen, a widely used anti-estrogen therapy (129). Tamoxifen resistance is thought to be mediated by the over-expression of ERBB2, a major driver of breast cancer (123). Trastuzumab, a humanized monoclonal antibody, has been successfully used for treating approximately $50 \%$ of can cers that over-express E RBB2 (121). Interestingly, B T-474 c ells ha ve be en demonstrated to develop resistance to trastuzumab (124). The BT-474 cell line, therefore, offers a uni que oppor tunity a s a t arget for de veloping an i maging a gent $\mathrm{c}$ apable of detecting $\mathrm{b}$ reast car cinomas $\mathrm{s}$ usceptible $\mathrm{t}$ or esistance $\mathrm{t}$ o $\mathrm{m}$ ultiple $\mathrm{t}$ argeted $\mathrm{t}$ herapies, 
namely tamoxifen and trastruzumab. A targeted agent specific for BT-474 breast cancer may offer a novel method of identifying resistance susceptible cancers prior to treatment.

Bacteriophage ( phage) display ha s be en us ed to s uccessfully s elect i maging agents, such as peptides, with the affinity and specificity to image human cancer in vivo (86). Following the discovery that phages tolerate insertion of foreign peptide sequences while retaining the functions of infection and replication, phage display has been used to identify peptides from a library of random sequences based on a desired target (40). The power of pha ge di splay is de rived f rom the a bility t o t est up t o $10^{9}$ unique pha ge displayed sequences simultaneously for the optimal peptide based on a desired function. Phages are incubated with a target, allowing a portion to bind, while the unbound phages are removed. Although only a small portion may bind to the target, the recovered phages are ex ponentially $\mathrm{i}$ ncreased $\mathrm{b}$ y propagation $\mathrm{i} \mathrm{n} \mathrm{h}$ ost $\mathrm{b}$ acterial cell. $\mathrm{T}$ he enriched subpopulation i s t hen subjected t o a $\mathrm{s}$ ubsequent $\mathrm{r}$ ound of $\mathrm{s}$ election, pr oviding a $\mathrm{n}$ enhanced 1 evel of $\mathrm{c}$ ompetition due $\mathrm{t}$ o t he $\mathrm{i}$ ncreased num ber of $\mathrm{t}$ arget-avid $\mathrm{c}$ lones represented in the total phage population. Following a number of rounds of selection, the output of pha ge generally $\mathrm{r}$ epresents the fittest $\mathrm{c}$ lones for $\mathrm{t}$ he $\mathrm{d}$ esired function. $\mathrm{T}$ his process can be us ed to i dentify peptides which bind specifically to an antigen which is expressed or ov er-expressed in c ancer, in a ddition to i dentifying pe ptides s pecific for breast can cer c ell lines (130). Phage display has been us ed in vitro to identify peptides which bi nd to a hos t of a ntigens a nd i mage t umor cells in vivo, i ncluding i ntegrins, receptor tyrosine kinases, and carbohydrate antigens (43-45).

In vivo phage display provides the combinatorial power of a traditional selection, while offering unique advantages. By probing a tumor in the context of a living system, 103 
antigens are more likely to be presented in the manner in which they would be found in a patient. The s election is f avorably $\mathrm{b}$ iased $t$ owards an tigens $t$ hat ar e a ccessible t o the tumor va sculature, which may differ from those identified ex vivo or in vitro (49). An additional benefit is that peptides must successfully avoid binding to antigens displayed in non-target organs in order to be captured, decreasing the likelihood of non-target organ uptake. In vivo phage display has been demonstrated to select peptides that bind human tumors a nd s pecifically $t$ arget $t$ he va sculature of $m$ ost or gans, $i$ ncluding $t$ umor vasculature $(50,108)$.

In vivo phage di splay is e specially us eful $\mathrm{w}$ hen a s pecific protein $\mathrm{t}$ arget is not known. For example, B T-474 cells are known to express ERBB2 and estrogen receptor, however, neither marker by its elf is predictive of susceptibility to resistance $(124,128$, 129). It is extremely likely, however, that many potential targets on BT-474 c ells may serve not onl y a s nove 1 br east $\mathrm{c}$ ancer a ntigens, but a lso a s pr edictors of therapeutic resistance. In vivo phage di splay $\mathrm{c}$ an $\mathrm{s}$ erve as a $\mathrm{n}$ i nitial $\mathrm{s}$ creen for $\mathrm{p}$ eptides $\mathrm{w}$ hich specifically target BT-474 cells, providing the b asis for de velopment an imaging agent for $\mathrm{further}$ refinement a nd ch aracterization. It was hypothesized that a nove 1 BT-474 targeted peptide could b e s elected by in vivo phage di splay, which w ould pos sess the capability of detecting human breast tumors in xenografted mice. To test this, 4 rounds of in vivo selection $\mathrm{w}$ ere performed, a nd i ndividual $\mathrm{p}$ hages $\mathrm{w}$ ere characterized $\mathrm{f}$ or $\mathrm{t}$ heir ability t o bi nd BT-474 $\mathrm{c}$ ells in vitro. A p eptide corresponding to a p hage $\mathrm{w}$ ith hi gh specificity and affinity for the target cells was synthesized as a biotinylated conjugate and tested $\mathrm{f}$ or $\mathrm{c}$ ell bi nding us ing $\mathrm{f}$ luorescent $\mathrm{c}$ onfocal microscopy, $\mathrm{f}$ low $\mathrm{c}$ ytometry a nd colorimetric binding assays. Retained affinity and specificity of the biotinylated peptide 
in vitro warranted analysis of the peptide as an ${ }^{111}$ In-radiolabeled SPECT imaging agent. Following c onfirmation of s pecificity and hi gh affinity of the radiolabeled pe ptide, in vivo biodistribution $\mathrm{w}$ as a ssessed. F inally, the peptide $\mathrm{w}$ as t ested a $\mathrm{s}$ for the a bility to detect BT-474 human breast tumors by SPECT/CT. 


\section{Materials and Methods}

\section{Materials}

Materials for cell culture were obtained from Invitrogen (Carlsbad, CA). Unless otherwise s pecified, all o ther $\mathrm{m}$ aterials w ere $\mathrm{p}$ urchased $\mathrm{f}$ rom $\mathrm{S}$ igma $\mathrm{C}$ hemical $\mathrm{C}$ o. ( $\mathrm{St}$. Louis, MO).

\section{Cell Lines}

BT-474 cells were grown in RPMI-1640 with $10 \%$ heat-inactivated FBS, $4.5 \mathrm{~g} / \mathrm{L}$ D-glucose, $2.83 \mathrm{~g} / \mathrm{L}$ HEPES buffer, L-glutamine, $1.5 \mathrm{~g} / \mathrm{L}$ s odium bicarbonate, $110 \mathrm{~m} \mathrm{~g} / \mathrm{L}$ sodium pyruvate, and $48 \mu \mathrm{g} / \mathrm{ml}$ gentamicin at $37^{\circ} \mathrm{C}$ in $5 \% \mathrm{CO}_{2} .184 \mathrm{~A} .1$ cells were grown in R PMI $1640 \mathrm{w}$ ith $10 \% \mathrm{FBS}$ and $48 \mu \mathrm{g} / \mathrm{ml}$ gentamicin. Cell 1 ines w ere examined for viability and presence of pathogens prior to injection into mice.

\section{Mouse Strains and Handling}

Four- to 6 -week-old athymic $\mathrm{n}$ ude $\mathrm{m}$ ice were $\mathrm{p}$ urchased from $\mathrm{H}$ arlan (Indianapolis, IN) and maintained i $\mathrm{n}$ a pproved pa thogen-free $\mathrm{i}$ nstitutional hous ing. Animal studies were conducted as outlined in the NIH Guidelines for the Care and Use of Laboratory Animals and the Policy and Procedures for Animal Research of the Harry S. Truman V eterans M emorial Hospital. To e stablish s olid tu mors, B T-474 hum an br east cancer cells $\left(5 \times 10^{6}\right)$ were subcutaneously injected into the rear flank of a thymic nude 
mice. $\mathrm{T}$ ime-release $17 \beta$-estradiol $\mathrm{p}$ ellets ( Innovative $\mathrm{R}$ esearch, $\mathrm{S}$ arasota, $\mathrm{F} \mathrm{L}$ ) w ere implanted s ubcutaneously to s upplement $t$ umor $g$ rowth. $V$ isible $t$ umors f ormed a fter approximately $5 \mathrm{w}$ eeks. Mice i njected $\mathrm{w}$ ith ei ther $\mathrm{p}$ hage or $\mathrm{r}$ adiolabeled $\mathrm{p}$ eptide $\mathrm{w}$ ere euthanized prior to excision of tumors and organs of interest.

\section{In Vivo Phage Display Selection}

A library of phage displaying 15 random amino acids from the N-terminal tip of cpIII, in the fUSE5 vector, was a generous gift from Dr. George P. S mith. In or der to remove pha ges $\mathrm{w}$ ith a propensity $\mathrm{t}$ o bi nd $\mathrm{n}$ ormal $\mathrm{t}$ issues a nd va sculature, $1 \mathrm{x} 10^{12}$ transducing units (TU) of library was injected into non-tumor bearing mice and unbound phages were $\mathrm{r}$ ecovered from $\mathrm{t}$ he bl ood $15 \mathrm{~m}$ in a fter i nitial i njection, a mplified a nd purified, as previously described (131). The pre-cleared library was used for the ensuing rounds of s election in BT-474 t umor be aring mice. Briefly, $1 \times 10^{12}$ TU of $\mathrm{p}$ re-cleared phage was injected into BT-474 xenografted mice and allowed to circulate for $4 \mathrm{~h}$. Mice were anesthetized and t umors excised and frozen in 1 iquid ni trogen. The t umors w ere manually hom ogenized and washed $10 \mathrm{x}$ with Tris buffered saline with $0.1 \%$ Tween-20 $(0.1 \%$ TBST $)$ in order to remove non-specifically bound phages. The tumor homogenate was t hen i ncubated with 2.5\% ( w:v) 3-[(3-Cholamidopropyl)dimethylammonio]-1propanesulfonate (CHAPS) for $1 \mathrm{~h}$ to elute bound phages and disrupt cells for recovery of any phage that had been internalized by cells. Eluted phages were used to infect log phase K91BK Escherichia coli (E. coli) for a mplification, f ollowed b y p urification b y polyethylene glycol as described previously (76). The tumor-avid, amplified library was used for the subsequent round of selection, which proceeded exactly as the first round. A 
total of four rounds of selection were performed in BT-474 human breast tumor bearing mice.

\section{Analysis of Selected Phages}

Following the fourth round of selection, 96 individual phages were sequenced in order t o a scertain their displayed pe ptides. The s equences $\mathrm{w}$ ere analyzed for $\mathrm{m}$ ultiple occurrences, pa rtial s equence $\mathrm{m}$ ultiple oc currences, a mino acid frequency and b y algorithms in cluding b asic lo cal a lignment s earch to ol (BLAST) and the scanner an d reporter o f t arget-unrelated pe ptides algorithm ( SAROTUP) $(77,78)$. P hage di splayed peptides found in previous unrelated selections were removed from consideration and 14 phages $\mathrm{w}$ ere chosen for c ell bi nding a ssays. E ach pur ified pha ge $\mathrm{c}$ lone $\mathrm{w}$ as di luted to $1 \times 10^{8} \mathrm{TU} / \mathrm{mL}$ in R PMI and $100 \mu \mathrm{L}$ w as i ncubated w ith e ither $1 \times 10^{5} \mathrm{BT}-474$ hum an breast cancer or $184 \mathrm{~A} .1$ normal breast epithelial cells for $1 \mathrm{~h}$ at $37^{\circ} \mathrm{C}$. Cells were washed three $t$ imes w ith $0.1 \%$ TBST a nd bound pha ge were e luted b y i ncubation w ith $2.5 \%$ CHAPS at $4^{\circ} \mathrm{C}$ for $1 \mathrm{~h}$. Eluted phage were quantified by titration and infection of E. coli.

\section{Peptide Synthesis}

The amino acid s equence corresponding to the displayed peptide of clone 51 , in addition to the $\mathrm{N}$-terminal 7 a mino a cid s equence $(51 \mathrm{~N})$ and $\mathrm{C}$-terminal 8 a mino a cid sequence ( 51C) a nd a VEGF i nhibiting pe ptide ( V1) w ere c hemically synthesized. Synthesis oc curred using an A dvanced C hem Tech 396 m ultiple pe ptide s ynthesizer (Advanced C hem T ech, Louisville, K Y) b y s olid pha se F MOC c hemistry. Biotin w as covalently c oupled to e ach pe ptide a t the $n$-terminus w ith a tripeptide GSG tripeptide 
spacer. The full length 51 peptide was also conjugated to 1,4,7,10-tetraazacyclododecane1,4,7,10-tetraacetic acid (DOTA) (Macrocyclic, Inc. Dallas, TX) by a GSG spacer.

\section{Fluorescent Microscopy}

BT-474, 184A .1 a nd HUVEC hum an e ndothelial c ells w ere f ixed i n 4\% paraformaldehyde an $\mathrm{d} d$ ried ont o $\mathrm{m}$ icroscope $\mathrm{s}$ lides. Following rehydration $\mathrm{w}$ ith T BS, cells w ere bl ocked w ith 6\% ( w:v) bovi ne s erum a lbumin ( BSA) for $1 \mathrm{~h}$ a $\mathrm{tr}$ oom temperature. P eptides $51,51 \mathrm{~N}$ and $\mathrm{V} 1$ were di luted to $10 \mu \mathrm{M}$ in $0.1 \%$ T BST. A fter blocking, $100 \mu \mathrm{L}$ of the appropriate peptide solution was added to cells and allowed to bind for $1 \mathrm{~h}$ a t room temperature. Slides were washed three times with $0.1 \%$ TBST and $100 \mu \mathrm{L}$ of $\alpha$-Biotin-Alexafluor $488 \mathrm{c}$ onjugated monoclonal a ntibody di luted 1:1000 in $0.1 \%$ TBST was added to cells and incubated at room temperature for $1 \mathrm{~h}$. S lides were washed $3 \mathrm{x}$ with $0.1 \%$ TBST and analyzed by an epifluorescent-equipped Nikon T1-SM inverted microscope (Nikon, Melville, NY).

\section{Flow Cytometry Analysis of Peptide Binding}

In the s ame m anner as fluorescent $\mathrm{m}$ icroscopy, B T-474, 184A .1 and HUVEC cells were fixed and diluted to $1 \times 10^{6}$ cells $/ \mathrm{mL}$ in RPMI and preincubated with a 1:1000 dilution of $\alpha$-Biotin-Alexafluor 488 a ntibody. Peptides $(51,51 \mathrm{~N}, \mathrm{~V} 1)$ were diluted to 10 $\mu \mathrm{M}$ and incubated with cells for $1 \mathrm{~h}$ a t $37^{\circ} \mathrm{C}$. Cells were washed three times with $0.1 \%$ TBST, counted and fluorescence quantified per cell by a BD F ACScan flow cytometer (BD Biosciences, San Jose, CA). 


\section{Well Colorimetric Cell Binding Assay}

BT-474 and 184A.1 c ells w ere g rown to 80\% c onfluency in T PP 96 well flat bottom tissue culture plates and fixed with 4\% paraformaldehyde. Biotinylated 51, 51N and 51C were diluted to appropriate concentrations in RPMI and incubated with cells for $1 \mathrm{~h}$ a t room temperature. Cells were washed three times with $0.1 \%$ T BST and $100 \mu \mathrm{L}$ horseradish peroxidase-conjugated streptavidin $(1 \mu \mathrm{g} / \mathrm{mL})$ was added to cells and allowed to bind for $1 \mathrm{~h}$ a t room temperature. A gain, washing oc curred in the same manner and $100 \mu \mathrm{L}$ of 2,2'-azino-bis(3-ethylbenzothiazoline-6-sulfonic acid) was incubated with cells for $15 \mathrm{~m}$ in at room temperature. Color de velopment $\mathrm{w}$ as terminated $\mathrm{b} y$ the a ddition of 1\% (w:v) sodium dodecyl sulfate and absorbance at $405 \mathrm{~nm}$ was quantified.

\section{Radiolabeling and Peptide Cell Binding Assays}

DOTA-conjugated 51 pe ptide was di luted to $1 \mathrm{~m} \mathrm{~g} / \mathrm{mL}$ in water and $20 \mu \mathrm{L}$ w as added to $200 \mu \mathrm{L}$ of $0.1 \mathrm{M}$ ammonium acetate and $18.5 \mathrm{MBq}$ of ${ }^{111} \mathrm{InCl}_{3}$. The reaction was incubated a $85^{\circ} \mathrm{C}$ f or $1 \mathrm{ha}$ nd t erminated by the a ddition of $10 \mu \mathrm{L}$ of $0.1 \mathrm{M}$ ethylenediaminetetraacetic acid. R eversed phase HPLC us ing a linear gradient from 5 $95 \%$ acetonitrile and $0.1 \%(\mathrm{v}: \mathrm{v})$ trifluoroacetic acid was used to purify the radiolabeled peptide. For cell binding analysis, BT-474 cells were diluted to $1 \times 10^{7}$ cells $/ \mathrm{mL}$ in RPMI

with 1\% (w:v) BSA. Purified, radiolabeled ${ }^{111}$ In-DOTA-51 peptide was diluted to $1 \times 10^{6}$ $\mathrm{CPM} / \mathrm{mL}$ in R PMI pl us $1 \%$ B SA and $100 \mu \mathrm{L}$ w ere added to $200 \mu \mathrm{L}$ c ells. Unlabeled DOTA-51 was serial diluted and added to radiolabeled peptide and cells at concentrations from $10 \mathrm{pM}$ to $1 \mu \mathrm{M}$ and incubated at $37^{\circ} \mathrm{C}$ for $1 \mathrm{~h}$. Cells were washed with ice cold 
PBS with $0.1 \%$ BSA three times and counted by ga mma counter (Perkin Elmer, S anta Clara, CA).

\section{Radiolabeled Peptide Biodistribution}

${ }^{111}$ In-DOTA-51 peptide was radiolabeled and purified as described in in vitro cell binding. Radiolabeled peptide was then diluted with sterile PBS to $1.85 \mathrm{MBq} / \mathrm{mL}$. Four mice bearing BT-474 tumors were intravenously injected with $100 \mu \mathrm{L}$ of ${ }^{111}$ In-DOTA-51 and sacrificed at $2 \mathrm{~h}$ post-injection. Following sacrifice, pertinent organs and tissues were excised, weighed and counted via gamma counter. Uptake was normalized by weight as percentage of injected dose per gram of tissue $(\% \mathrm{ID} / \mathrm{g})$.

\section{MicroSPECT/CT Imaging}

${ }^{111} \mathrm{In}$-DOTA-51 was radiolabeled, purified and diluted to $11.1 \mathrm{MBq}$ in $100 \mu \mathrm{L}$ of sterile PBS. The radiolabeled peptide was injected intravenously into a mouse bearing a BT-474 hum an breast t umor x enograft. A fter a llowing the pe ptide to c irculate for $2 \mathrm{~h}$ post-injection, the mouse was sacrificed and imaged at the Biomolecular Imaging Center at the Harry S. Truman Veterans Memorial Hospital. Acquisition of the image proceeded for $7 \mathrm{~h}$ u sing a S iemens Inveon Micro-SPECT/CT ( Siemens, K noxville, TN) o utfitted with $\mathrm{m}$ ouse $\mathrm{w}$ hole body $1.0 \mathrm{~m} \mathrm{~m} \mathrm{c}$ ollimators. P rocessing o $\mathrm{ft}$ he i mage da ta was accomplished us ing Inveon $\mathrm{R}$ esearch $\mathrm{W}$ orkplace pr ocessing $\mathrm{s}$ oftware. $\mathrm{F}$ an $\mathrm{b}$ eam (Feldkamp) f iltered $\mathrm{b}$ ack $\mathrm{p}$ rojection a lgorithms were e mployed t o r econstruct t he C $\mathrm{T}$ tomographic image. 


\section{Results}

\section{In Vivo Selected Phage Characterization}

Following the completion of four rounds of in vivo selection, 96 individual phages were i solated and their relevant DNA s equenced to obtain the di splayed peptide a mino acid $\mathrm{s}$ equence. $\mathrm{S}$ election of pha ges $\mathrm{f}$ or $\mathrm{c}$ ell bi nding $\mathrm{c}$ haracterization $\mathrm{w}$ as $\mathrm{f}$ irst accomplished $\mathrm{b}$ y a nalyzing pe ptides $\mathrm{f}$ or $\mathrm{t}$ he presence of $\mathrm{t}$ arget unr elated pe ptides. Sequences w ere compared to those from pr evious publ ished s elections $w$ ith unr elated targets using the scanner and reporter of target unrelated peptides algorithm (78). Of the 96 total s equences, 28 were r eported in pr evious s elections. P hages that bound $\mathrm{t}$ argets unrelated to breast cancer, including the blood-brain barrier, hemagglutinin A, polyclonal rabbit a ntibody, a nd no rmal t issue w ere e xcluded f rom c onsideration (41, 132 -134). Instead, 14 phages unique t o the s election, and lis ted in Figure 4.1A, w ere chosen because they w ere found m ultiple $t$ imes, or a p ortion of the s equence was present in multiple phages. Phages were purified and analyzed for BT-474 specificity and apparent affinity.

Individual pha ges were tested for their ability to selectively bind BT-474 human breast cancer cells while not binding $184 \mathrm{~A} .1 \mathrm{c}$ ells, a n ormal b reast e pithelial c ell line. Recovered pha ges w ere normalized to the bi nding of i nsertless w ild-type p hage as an internal $\mathrm{c}$ ontrol be tween e xperiments. $\mathrm{T}$ he $\mathrm{r}$ elative bi nding $\mathrm{r}$ atio of e ach ph age i $\mathrm{n}$ comparison to the wild-type phage was used to assess the relative specificity and affinity 


A. \begin{tabular}{|c|c|}
\hline Phage & Sequence \\
\hline Clone 51 & ATWLPVPVVGYFMASA \\
\hline Clone 93 & ASWVAPPLWLGPFALP \\
\hline Clone 34 & ANFVGWPVGLWTGFDV \\
\hline Clone 19 & AGLGVLGSAVVVSRAS \\
\hline Clone 8 & ARGLFPFFYLLGPAGG \\
\hline Clone 32 & AFPGFLSLGPFSFY PE \\
\hline Clone 81 & AGLLPGSFVGQAYWLP \\
\hline Clone 1 & ADGPHFFSPAVLFPYS \\
\hline Clone 22 & ACARGEYFACSAFRVF \\
\hline Clone 62 & AGTIVLTSARAPLGLL \\
\hline Clone 24 & AFDRASFCSVFAGPDC \\
\hline Clone 60 & AVPWAGSSLYAILVPT \\
\hline Clone 44 & AIVEDLVAFRPWVIG \\
\hline Clone 42 & APRIFAYRGSSDRLHL \\
\hline
\end{tabular}

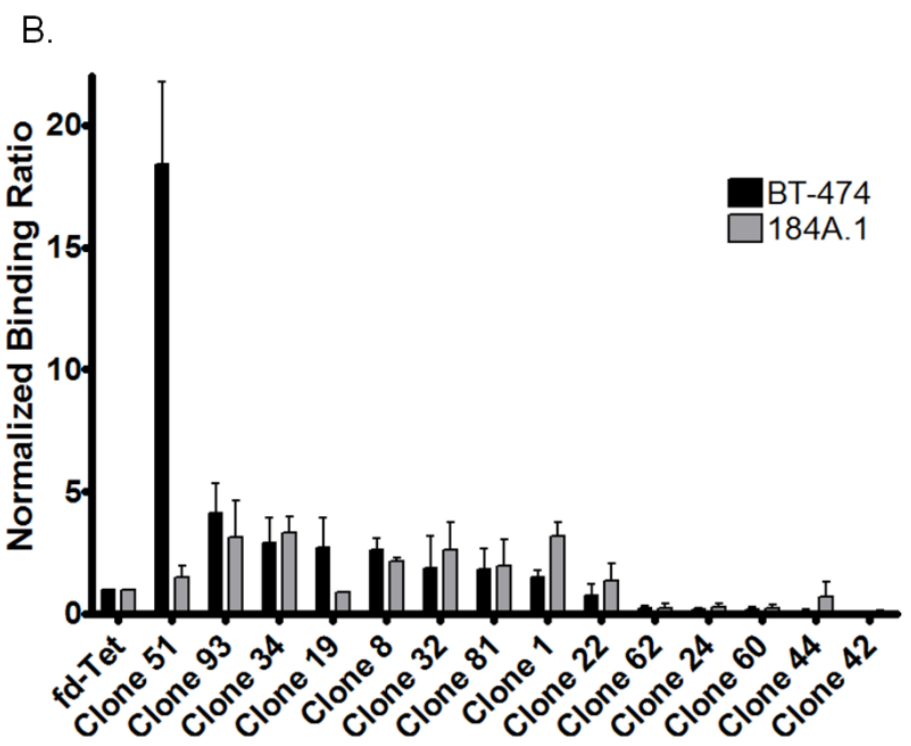

Figure 4.1 Round 4 of the in vivo phage di splay s election $w$ as s equenced a nd 14 individual pha ges w ere chosen for cell bi nding analysis. A) Individual pha ge a nd the corresponding a mino a cid s equence a re de picted. B) Individual pha ges were incubated with e ither ta rget BT-474 c ells or nor mal 184 A.1 br east epithelial c ells. T otal bound phages were quantified and normalized to wild-type phage. Shaded bars represent a mean of three replicate experiments, error bars denote standard deviation. 
of e ach di splayed pe ptide ( Figure 4.1B). O f t he 14 pha ges a nalyzed, 5 bound 2 -fold greater o $\mathrm{r} h$ igher th an w ild-type $\mathrm{t}$ o t he $\mathrm{t}$ arget $\mathrm{B} \mathrm{T}-474 \mathrm{c}$ ell line. $\mathrm{H}$ owever, $\mathrm{w}$ hen accounting for specificity by assessing the binding to 184A.1 breast epithelial cells, only 2 clones appeared to be specific for BT-474 cells. Clones 51 and 19 bound 18.4 and 2.7 times $\mathrm{h}$ igher to B T-474 c ells th an the wild-type phage, r espectively. A dditionally, the phages pr eferentially bo und br east c ancer c ells, with bi nding ratios to B T-474/184A.1 cells of 1.48 for Clone 51 and 0.78 for Clone 19 . Clone 51, which bound nearly 7 times more to B T-474 c ells than a ny ot her pha ge and di d not bind nor mal br east e pithelial binding, $w$ as c hosen for i nvestigation of $i$ ts di splayed pe ptide out side of the ph age scaffolding.

\section{Peptide 51 In Vitro Cell Binding}

Peptide 51 ( ATWLPVPVVGYFMASA) w as c ovalently 1 inked $\mathrm{t}$ o bi otin $\mathrm{f}$ or detection $\mathrm{i} \mathrm{n} \mathrm{c}$ ell bi nding assays. $\mathrm{T}$ he $\mathrm{p}$ eptide $\mathrm{w}$ as $\mathrm{f}$ irst analyzed by $\mathrm{f}$ luorescent microscopy as a qualitative assessment of binding. Fluorescent images demonstrated that the peptide bound to BT-474 human breast cancer cells and had no detectable binding to normal $\mathrm{b}$ reast e pithelial c ells ( Figure $4.2 \mathrm{~A}$ ). A $\mathrm{c}$ ontrol pe ptide chosen $\mathrm{f}$ rom a $\mathrm{t}$ arget unrelated phage was used as a control and demonstrated no binding to either cell line. For confirmation of the results of fluorescent microscopy and to attempt to quantify peptide 51 binding, flow cytometry was performed. Peptide 51 bound w ith moderate affinity for BT-474 cells, with a calculated $\mathrm{EC}_{50}=2.33 \pm 0.66 \mu \mathrm{M}$ (Figure 4.2B). Binding to BT-474 cells was also significantly higher than $184 \mathrm{~A} .1$ cells at all peptide concentrations 
A

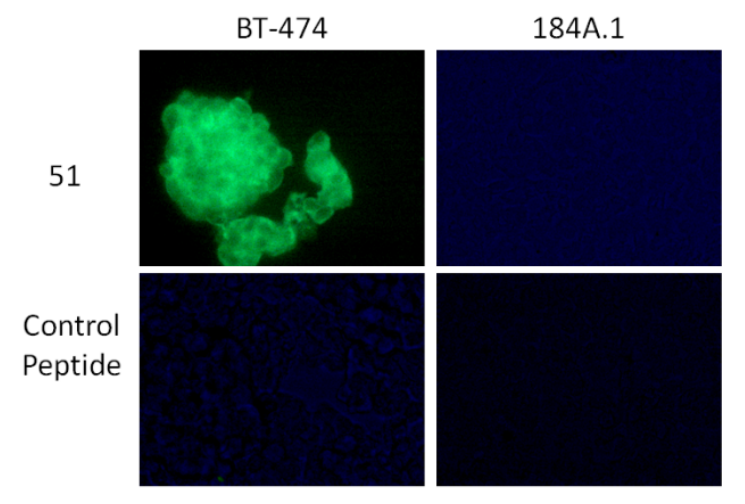

B

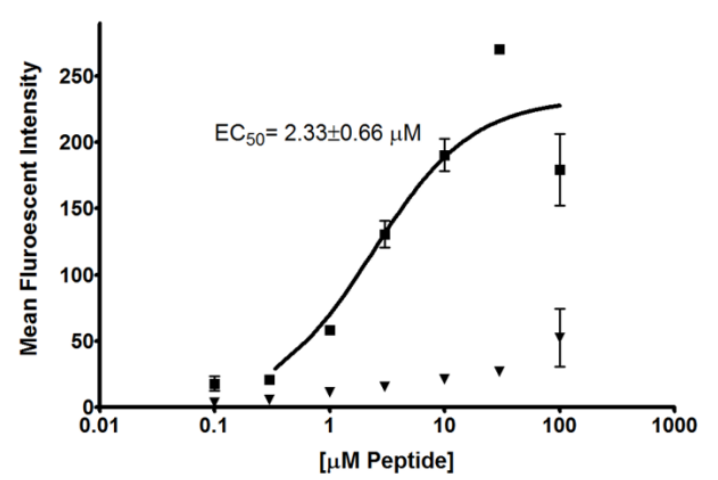

Figure 4.2 A) Biotinylated peptide 51 and a control peptide were incubated with BT-474 human br east $\mathrm{c}$ ancer and 184A .1 nor mal b reast e pithelial c ells fixed ont o m icroscope slides. F ollowing w ashing, bound pe ptides w ere de tected b y addition of a $\mathrm{n}$ a nti-biotin Alexafluor 488 -conjugated antibody. S trong binding is obs erved for 51 with the target BT-474 cells, but not normal breast epithelial cells. The control peptide does not exhibit binding to either cell line. B) Peptide 51 was analyzed for BT-474 and 184A.1 specificity and affinity by flow cytometry. Following incubation of peptide with cells, bound peptide was d etected b y anti-biotin A lexafluor 488. S quares represent the m ean of 3 BT-474 replicates at the indicated peptide concentration, triangles represent the mean of $3184 \mathrm{~A} .1$ replicates. Error bars represent the standard deviation. 
analyzed, a nd pe ptide 51 bi nding t o 184A .1 cells di d not d isplay a sigmoid dose response, indicating a lack of specificity for the cells. A satisfactory affinity for BT-474 cells, in a ddition t o $\mathrm{m}$ inimal nor mal br east $\mathrm{t}$ issue bi nding, i ndicated $\mathrm{t}$ hat $\mathrm{t}$ he pe ptide would be a suitable candidate for development as a radiolabeled imaging agent.

\section{In Vitro and In Vivo ${ }^{111}$ In-DOTA-51 Analysis}

For $\mathrm{r}$ adiolabeled $\mathrm{p}$ eptide a ssessment, pe ptide $51 \mathrm{w}$ as c onjugated t o DOTA through an N-terminal GSG spacer and radiolabeled with ${ }^{111}$ In. ${ }^{111}$ In-DOTA-51 was first tested $\mathrm{f}$ or a $\mathrm{r}$ etained affinity $\mathrm{f}$ or BT-474 $\mathrm{c}$ ells in vitro using unl abeled pe ptide in a competition assay. The relative $\mathrm{IC}_{50}$ was calculated at $16 \pm 7 \mathrm{nM}$, an affinity comparable to previous pe ptides us ed for in vivo analysis (Figure 4.3) $(43,48) .{ }^{111}$ In-DOTA-51 w as injected in to mice bearing BT-474 hum an breast c ancer x enografts for pharmacokinetic analysis. T he bi odistribution of ${ }^{111} \mathrm{In}$-DOTA-51 $\mathrm{r}$ evealed tumor upt ake of $0.12 \pm 0.02$ $\% \mathrm{ID} / \mathrm{g}$ (Figure 4.4). The tumor to blood ratio was determined to be 2.3 and the tumor to muscle $\mathrm{r}$ atio $\mathrm{w}$ as 7.1 , i ndicating s pecificity of $\mathrm{t}$ he pe ptide for B T-474 hum an br east tumors. Tumor uptake in all other organs was low, further confirming tumor specificity. In pa rticular, or gans that c ould pr oduce ba ckground s ignal for br east $\mathrm{c}$ ancer i maging, including the he art $(0.04 \pm 0.01 \% \mathrm{ID} / \mathrm{g})$, and 1 ung $(0.13 \pm 0.03 \% \mathrm{ID} / \mathrm{g}) \mathrm{w}$ ere 1 ow (Figure 4.4). R adiosensitive or gan uptake, such as bone $(0.03 \pm 0.02 \% \mathrm{ID} / \mathrm{g}) \mathrm{w}$ as a lso $\mathrm{m}$ inimal (Figure 4.4), which is important in the development of a safe and effective radiolabeled imaging agent. SPECT/CT image analysis revealed high peptide uptake surrounding the tumor, in addition to kidney uptake, which coincided with the measured kidney retention of $30.4 \% \mathrm{ID} / \mathrm{g}$. (Figure 4.5 ). The pattern of tumor uptake 


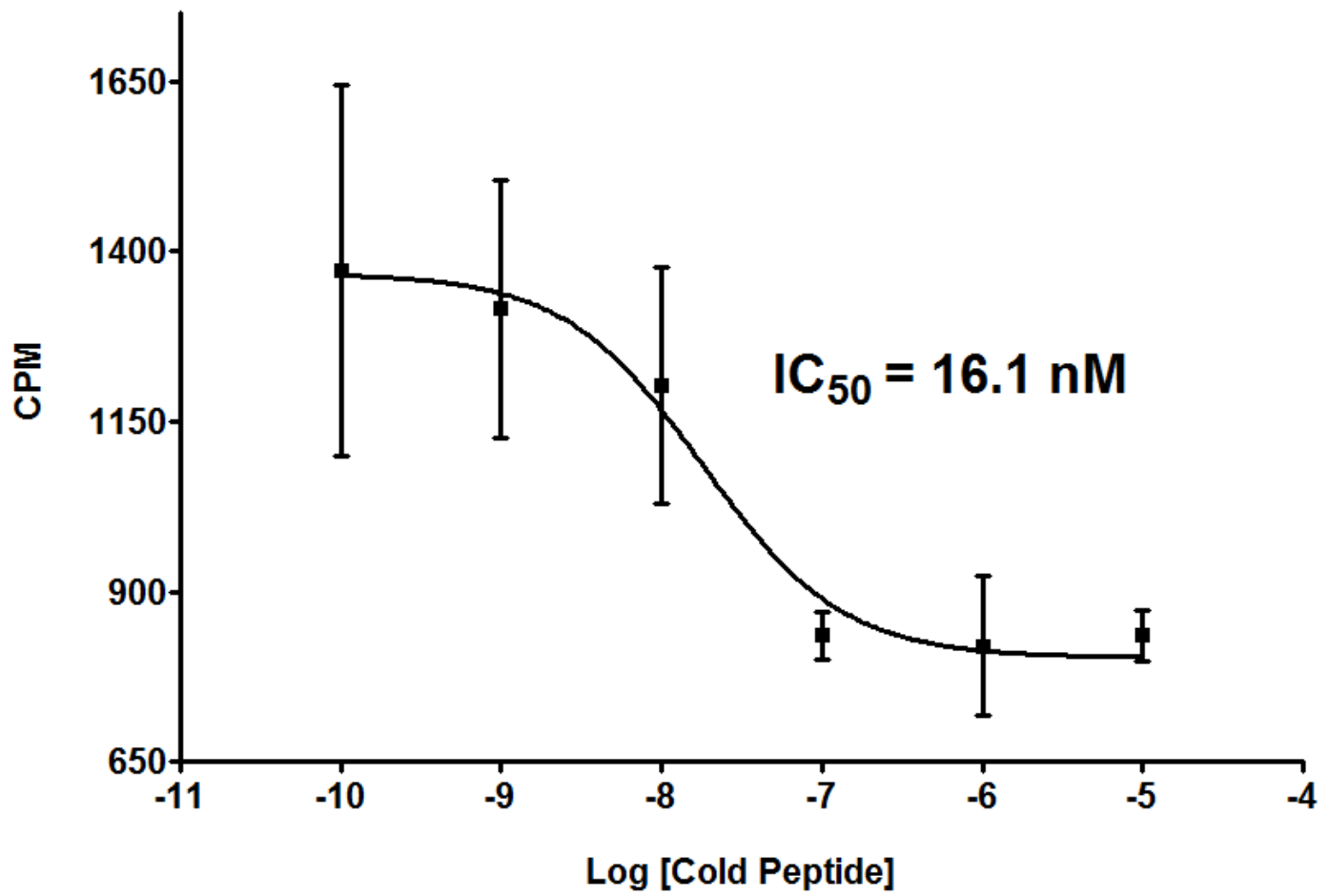

Figure 4.3 ${ }^{111}$ In-DOTA-51 was diluted to $1 \times 10^{6} \mathrm{CPM} / \mathrm{mL}$ in RPMI and $1 \%$ BSA and 100 $\mu \mathrm{L}$ w as a dded t o $1 \mathrm{~m}$ illion B T-474 c ells s uspended in $100 \mu \mathrm{L}$ o f t he s ame b uffer. Unlabeled D OTA-51 w as s erially diluted an $\mathrm{d}$ ad ded $\mathrm{t}$ o 1 abeled $\mathrm{p}$ eptide an $\mathrm{d}$ cells. Following $1 \mathrm{~h}$ incubation at $37^{\circ} \mathrm{C}$, cells were washed and bound radioactivity quantified. Square box es represent the $\mathrm{m}$ ean of $3 \mathrm{r}$ eplicates a nd e rror ba $\mathrm{rs} \mathrm{r}$ epresent $\mathrm{s}$ tandard deviation. CPM - Counts per min. 


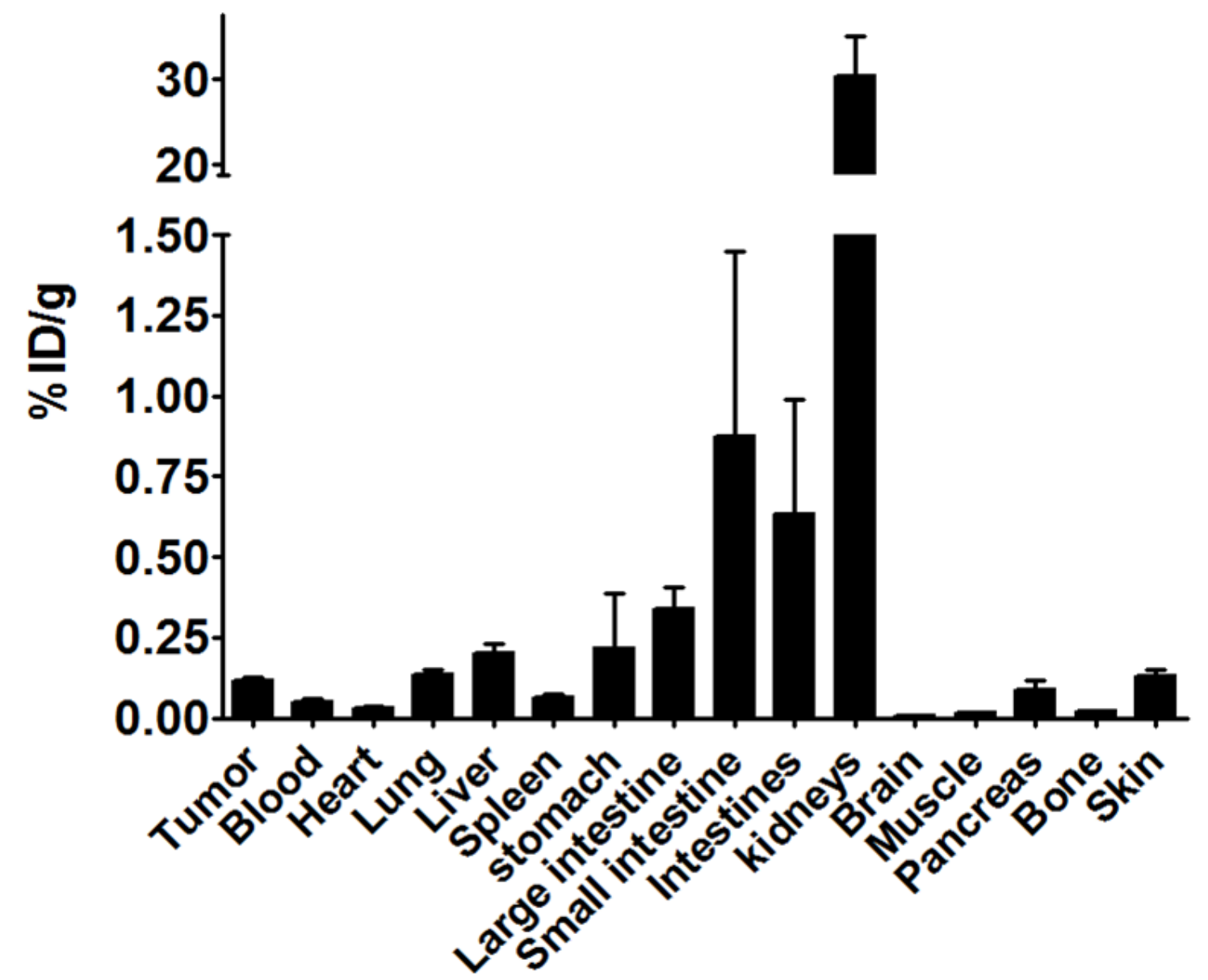

Figure 4.4 ${ }^{111}$ In-DOTA-51 $\mathrm{w}$ as prepared at $1.85 \mathrm{MBq} / \mathrm{mL}$ in s terile PBS and in jected into B T-474 $\mathrm{x}$ enograft be aring $\mathrm{m}$ ice. A t $2 \mathrm{~h}$ pos t-injection, a nimals $\mathrm{w}$ ere $\mathrm{s}$ acrificed, organs removed, and total radioactivity counted by gamma counter. Each bar represents the average of 4 mice, and error bars denote standard deviation. 


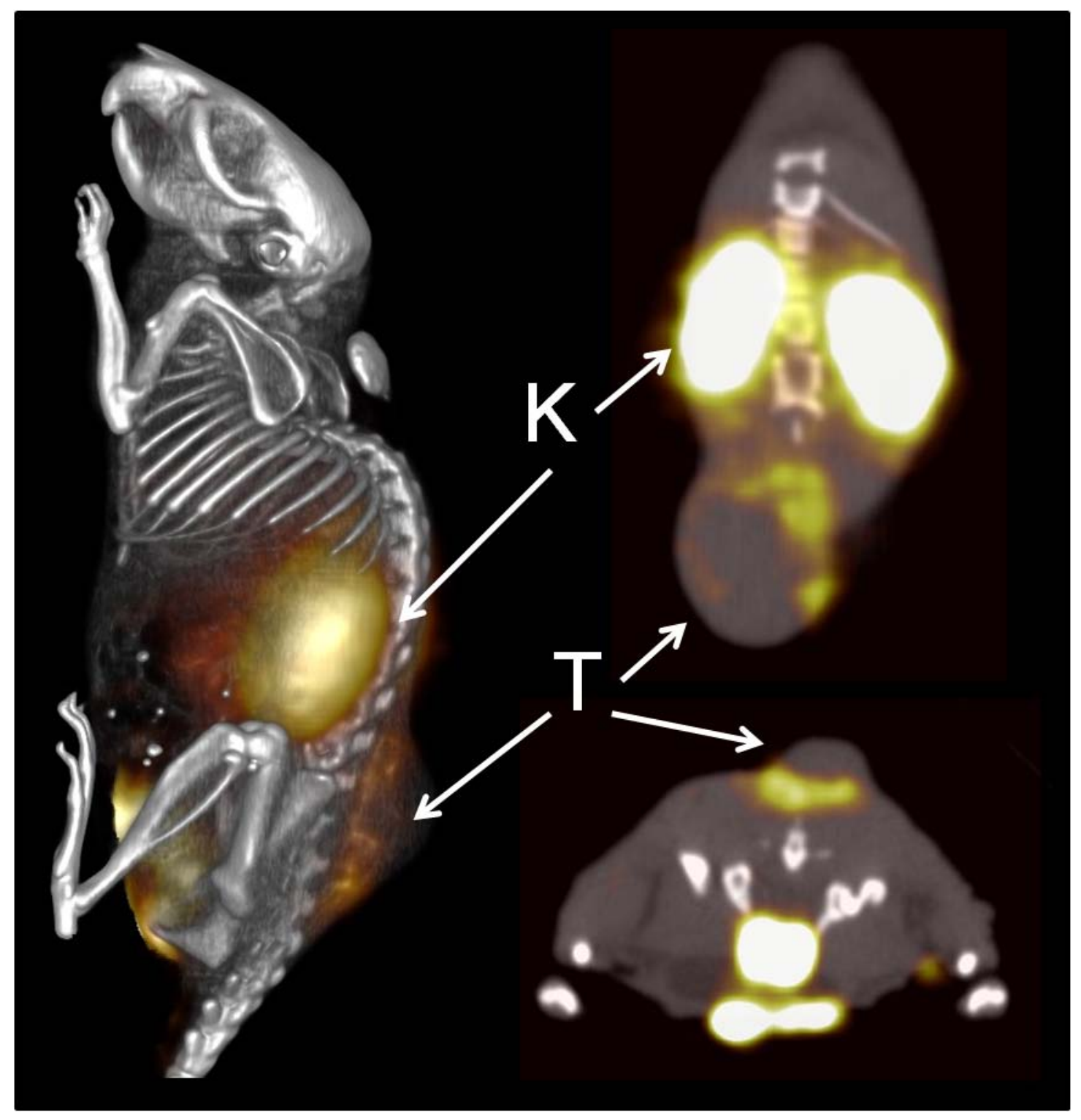

Figure 4.5 A BT-474 tumor bearing mouse was injected with $11.1 \mathrm{MBq}$ of ${ }^{111}$ In-DOTA51 and peptide was allowed to circulate for $2 \mathrm{~h}$ prior to imaging. SPECT/CT images were acquired overnight. All images are from the same mouse. T - Tumor, K - Kidney. 
was s imilar t o know $\mathrm{n} v$ asculature $\mathrm{t}$ argeting agents $\mathrm{s}$ uch a s radiolabeled a nti-vascular endothelial growth factor (VEGF) antibody and $\operatorname{RGD}(56,92)$. Although the sequences did not contain any well know n vasculature targeting motifs, such as RGD, peptide 51 sequence was rigorously compared to known vasculature targeting peptides in or der to determine if they shared any other partial homology.

Upon extensive literature review, it was noticed that peptide 51 shared a 5 amino acid hom ology with a peptide that had be en previously s elected by phage di splay and demonstrated to bind neuropilin-1 (Nrp1) and inhibit vascular endothelial growth factor (VEGF)-mediated an giogenesis (135). T he pe ptide, V 1 ( $\underline{\text { ATWLPPR), }}$ w as r emarkably similar to th e $\mathrm{N}$-terminal $\mathrm{r}$ esidues i n $\mathrm{C}$ lone 51, w hose full 1 ength sequence $\mathrm{w}$ as ATWLPVPVVGYFMASA. Since V1 did not share exact identity to peptide 51 and the peptides $\mathrm{w}$ ere o $\mathrm{f} d$ iffering s equence 1 engths, $\mathrm{p}$ reliminary s earches $\mathrm{f}$ or $\mathrm{t}$ arget $\mathrm{u}$ nrelated peptides did not identify the similarity between V1 and 51.

\section{Examining the Role of a Homologous V1 Sequence in Peptide 51}

Since peptide 51 shared homology with a vasculature antigen-targeting peptide, it was ne cessary to determine whether the properties of peptide 51 were mediated by the shared A TWLP s equence. Binding o f t he f ull 1 ength $\mathrm{p}$ eptide ( 51), the $\mathrm{N}$-terminal 7

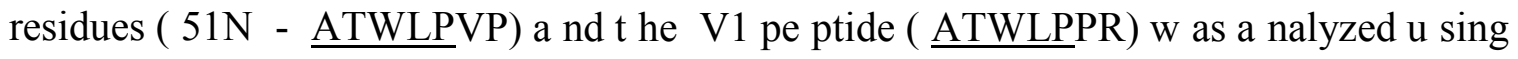
fluorescence microscopy for target B T-474 br east c ancer c ells, 184A.1 breast e pithelial cells, and an endothelial cell line demonstrated previously as a $\mathrm{t}$ arget of V1 (136). Full length 51 bound strongly to BT-474 cells, while neither $51 \mathrm{~N}$ nor V1 displayed detectable 

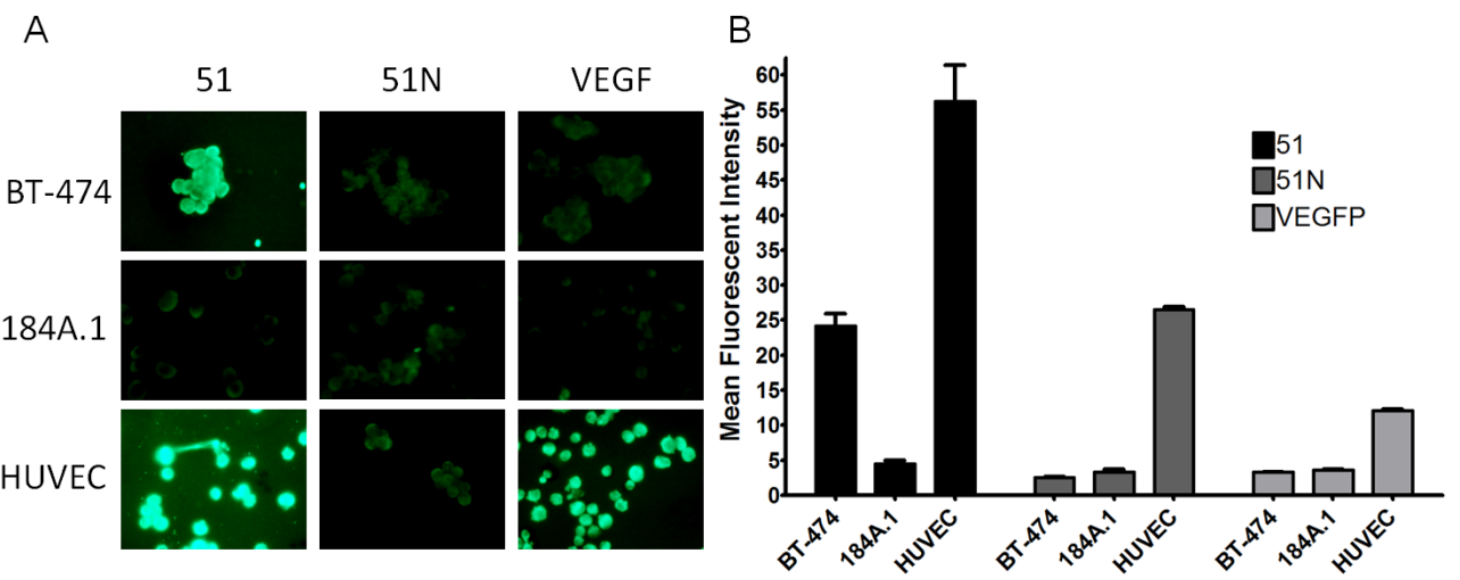

Figure 4.6 A) Biotinylated peptides w ere examined for B T-474, 184A.1 a nd HUVEC binding b y fluorescent c onfocal $\mathrm{m}$ icroscopy. Ten $\mu \mathrm{M}$ pe ptide $\mathrm{w}$ as i ncubated $\mathrm{w}$ ith $4 \%$ paraformaldehyde fixed cells dried onto microscope slides and peptide binding visualized by anti-biotin Alexafluor-488 conjugated antibody. B) Flow cytometry was performed to quantify peptide binding to cells. Binding is plotted as the mean fluorescent intensity of the total cell population. Bars illustrate a m ean of three replicate experiments and error bars correspond to the standard deviation. 
fluorescence to the same cell line, indicating only 51 visibly bound BT-474 cells (Figure 4.6A). All three peptides did not bind normal breast epithelial c ells. Interestingly, both full length 51 a nd V 1 b ound strongly to HUVEC endothelial cells, while $51 \mathrm{~N}$ binding was visibly weaker in fluorescent intensity than 51 or V1.

Confirmation and quantification of fluorescent peptide binding to each of the cell lines was investigated using flow cytometry. The mean fluorescence intensity (mean FI) was quantified for each cell line incubated with $10 \mu \mathrm{M}$ of peptide (Figure 4.6B). Peptide 51 had a significantly higher $(P<0.01)$ B T-474 cell binding ( mean F I $=24.2 \pm 2.98), 9.5$ and $7.4 \mathrm{t}$ imes higher than $51 \mathrm{~N}$ ( mean $\mathrm{FI}=2.53 \pm 0.11)$ and $\mathrm{V} 1($ mean $\mathrm{FI}=3.27 \pm 0.11)$, respectively. T he m ean F I of 51 for $184 \mathrm{~A} .1$ cells w as $4.47 \pm 0.90 \mathrm{i} \mathrm{n} \mathrm{comparison} \mathrm{to}$ $3.27 \pm 0.73$ for $51 \mathrm{~N}$ and $3.63 \pm 0.06$ for V1, indicating no binding of any pe ptide to the breast e pithelial $\mathrm{c}$ ell lin e. F inally, b inding to H UVEC c ells w as s ignificantly $\mathrm{h}$ igher $(P<0.05)$ for $51($ mean FI $=56.2 \pm 9.05)$ and V1 $($ mean F I $=26.5 \pm 0.46)$ than for $51 \mathrm{~N}$, which was consistent with fluorescent microscopy results.

Since the BT-474 targeting capability of 51 was not mediated by the N-terminal 7 residues, a pe ptide corresponding to the $\mathrm{C}$-terminal $9 \mathrm{r}$ esidues (51C - VVGYFMASA) was s ynthesized t o de termine i $\mathrm{ft}$ his s equence alone $\mathrm{c}$ ontributed t o the $\mathrm{c}$ ell bi nding properties. A 96-well, colorimetric cell binding assay was chosen to monitor binding over a number of concentrations for de termination of the specificity and a ffinity of $51,51 \mathrm{~N}$ and 51C. Peptide 51 demonstrated saturable binding and an $\mathrm{EC}_{50}=4.71 \pm 0.3 \mu \mathrm{M} .51 \mathrm{~N}$ did not reach binding saturation, and $51 \mathrm{C}$ bound with a calculated $\mathrm{EC}_{50}$ of approximately 2 $\mathrm{mM}, 1000 \mathrm{f}$ old w orse than full length 51 ( Figure 4.7). These results indicated that the 
BT-474 targeting properties of $51 \mathrm{w}$ ere not mediated by the $\mathrm{N}$ - or $\mathrm{C}$-terminal sequences by themselves. 
A

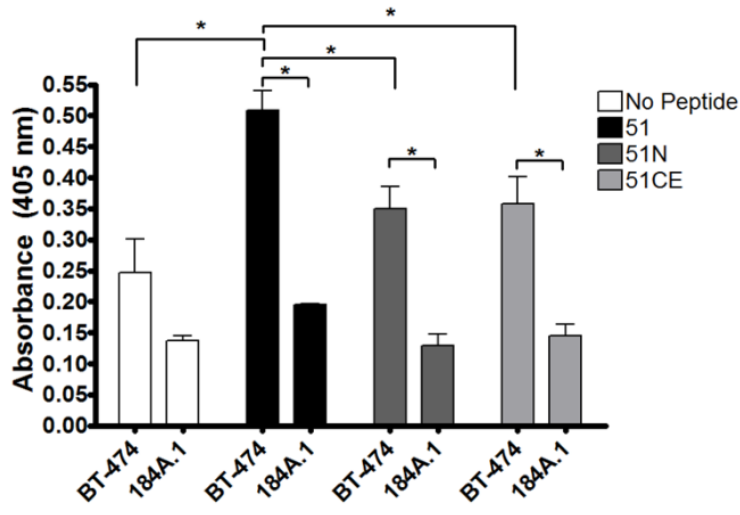

B

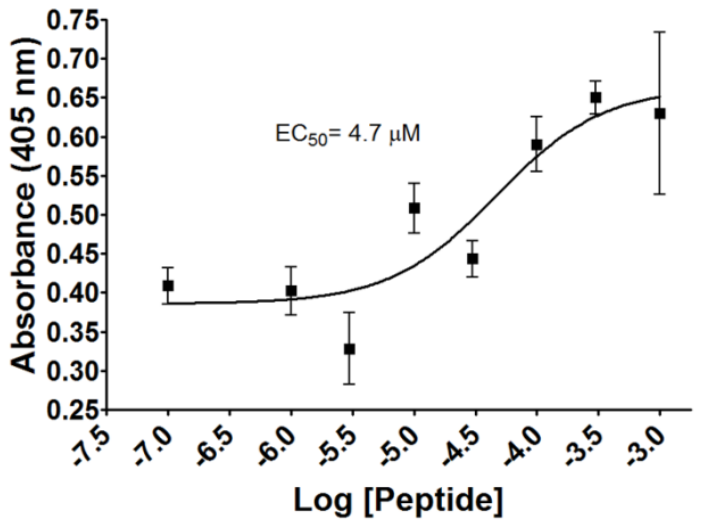

Figure 4.7 Full length (51), N-terminal (51N) a nd C-terminal (51C) truncated peptides were as sessed for BT-474 a nd 184A .1 c ell bi nding us ing a colorimetric $96 \mathrm{w}$ ell c ell binding a ssay. A ) $1 \mu \mathrm{M}$ bi otinylated pe ptide $\mathrm{w}$ as incubated $\mathrm{w}$ ith cells and binding $\mathrm{w}$ as detected by the a ddition of streptavidin-conjugated hor seradish pe roxidase followed by addition of 2,2 -azino-bis(3-ethylbenzothiazoline-6-sulfonic a cid). T otal bound pe ptide was measured by absorbance at $405 \mathrm{~nm}$. Bars represent a mean of 3 replicate experiments and error bars denote standard deviation. B) Peptide 51 binding from $10 \mathrm{nM}$ to $100 \mu \mathrm{M}$ to BT-474 cells is plotted for calculation of $\mathrm{EC}_{50}$. 
126 


\section{Discussion}

Detection an $\mathrm{d}$ ch aracterization of $\mathrm{b}$ reast carcinomas i s es sential $\mathrm{t}$ o effectively treating molecularly distinct malignancies. Therapeutic management of breast cancer has benefitted $\mathrm{f}$ rom $\mathrm{t}$ he $\mathrm{i}$ ntroduction of $\mathrm{t}$ argeted $\mathrm{t}$ herapies $\mathrm{i}$ ncluding $\mathrm{t}$ amoxifen a nd trastuzumab $(121,122)$. U nfortunately, r esistance has be en de monstrated to oc cur for both therapies, negating the beneficial effects of targeted therapy in certain patients (124, 129). Development of a targeted imaging agent, such as a radiolabeled peptide, that could detect human breast carcinomas and simultaneously reveal whether the tumor would be susceptible to de veloping therapeutic r esistance would, therefore, be hi ghly b eneficial. BT-474 human breast cancer cells express the targets of both tamoxifen and trastuzumab, and have innate resistance to tamoxifen and can develop resistance to trastuzumab (127, 137). $\mathrm{T}$ herefore, $\mathrm{t}$ his ce $11 \mathrm{l}$ ine $\mathrm{m}$ ay $\mathrm{s}$ erve as an $\mathrm{i}$ deal $\mathrm{m}$ odel $\mathrm{f}$ or $\mathrm{d}$ eveloping $\mathrm{t}$ argeted peptides for imaging therapy-resistant breast cancer.

In o rder to d evelop a peptide w ith B T-474 ima ging c apabilities, in vivo phage

display $\mathrm{w}$ as pe rformed with $\mathrm{m}$ ice be aring B T-474 hum an br east $\mathrm{c}$ ancer $\mathrm{x}$ enografts. Phages for further characterization were obtained by eliminating target unrelated phages, leaving 68 potential candidates. From these, 14 phages that were identified multiple times in the selection were chosen for cell binding analysis. Binding of the phages was assessed with B T-474 b reast can cer $t$ arget cel ls an d $184 \mathrm{~A} .1 \mathrm{n}$ ormal b reast ep ithelial cel ls as a negative control. Clone $51 \mathrm{w}$ as chosen for analysis as a synthesized peptide because in addition to minimal non-target binding, the phage bound over 18 times higher than wild- 
type pha ge t o B T-474 c ells. D ue t o i ts a pparent s uperior $\mathrm{t}$ argeting pr operties, $\mathrm{t}$ he displayed s equence of $\mathrm{c}$ lone $51 \mathrm{w}$ as s ynthesized a nd a nalyzed for c ell bi nding. Fluorescent $\mathrm{m}$ icroscopy c onfirmed BT-474 s pecific bi nding of the pe ptide, a nd flow cytometry was u sed to quantify a r elative $\mathrm{EC}_{50}=2.33 \mu \mathrm{M}$ of peptide 51 for the target cells. The peptide once again did not bind to $184 \mathrm{~A} .1$ cells at any concentration tested. A calculated $\mathrm{E}_{50}$ that ha $\mathrm{d}$ be en previously $\mathrm{d}$ emonstrated $\mathrm{t}$ o be $\mathrm{s}$ ufficient $\mathrm{f}$ or in vivo imaging, in addition to its specificity for BT-474 cells, lead to synthesis and analysis of the peptide as a radiotracer $(43,131)$.

Radiolabeling of the peptide for in vivo studies was accomplished by conjugating the pe ptide $t$ ot he $\mathrm{m}$ acrocyclic $\mathrm{c}$ helator D OTA a nd $\mathrm{i}$ ncubating $\mathrm{w}$ ith ${ }^{111}{ }^{1 n} \mathrm{I} \mathrm{T}$ he radiolabeled pe ptide $\mathrm{w}$ as $\mathrm{s}$ ubjected t o a pe ptide bi nding i nhibition a ssay t o c onfirm specificity and affinity. ${ }^{111}$ In-DOTA-51 binding inhibition was measured at a relative $\mathrm{IC}_{50}$ $=16.7 \mathrm{nM}$, confirming $\mathrm{r}$ etained a ffinity o $\mathrm{ft}$ he $\mathrm{r}$ adiolabeled $\mathrm{p}$ eptide. The di fference between the $\mathrm{EC}_{50}$ and $\mathrm{IC}_{50}$ could be the result of e nhanced a ffinity of the radiolabeled peptide, radiolabeling providing a more sensitive means of quantification, or a difference between the concentration of peptide necessary to reach half maximal s aturation $\left(\mathrm{EC}_{50}\right)$ and the c oncentration ne cessary to i nhibit $50 \%$ of s ubmaximal pe ptide binding $\left(\mathrm{IC}_{50}\right)$. Further ch aracterization $\mathrm{m}$ ay resolve $\mathrm{t}$ he difference; however, in vitro cell bi nding revealed that the peptide affinity had not been diminished by addition of a radiolabeled chelator, which was the goal of the assay. Therefore, ${ }^{111}$ In-DOTA-51 w as subsequently analyzed i n B T-474 t umor be aring $\mathrm{m}$ ice $\mathrm{f}$ or bi odistribution a nd SPECT $\mathrm{i}$ maging capability. T umor upt ake of the pe ptide was under $1 \% \mathrm{ID} / \mathrm{g}$, but hi ghly s pecific. T wo measures of specificity, tumor to blood (2.3) and muscle (7.1) ratios, w ere both greater 
than 1 , i ndicating tumor uptake was not mediated by blood pooling and was also tissue specific. SPECT imaging of the radiolabeled peptide revealed high uptake in the region surrounding t he $t$ umor, $c$ onsistent $w$ ith $r$ adiolabeled $R$ GD pe ptide and an a nti-VEGF antibody specific for tumor vasculature antigens $(56,92)$. Vasculature targeting peptides have been selected by in vivo and in vitro phage display previously, and it is known that a sequence a s s hort a s 3 a mino a cids, s uch a s R GD, i s s ufficient t o e ndow t umor vasculature $\mathrm{t}$ argeting $\mathrm{p}$ roperties to a pe ptide (45). $\mathrm{T}$ he hi ghly s imilar uptake pa tern between pe ptide 51 a nd ot her $\mathrm{t}$ umor va sculature $\mathrm{i}$ maging a gents $\mathrm{s}$ uggested th at the peptide may have similar targeting properties. Upon a detailed inspection of vasculature targeting peptide sequences in the literature, it was discovered that peptide 51 resembled a N rp1-targeted pe ptide s elected pr eviously b y pha ge di splay (135). The di splayed peptide of $\mathrm{C}$ lone 51, ATWLPVPVVGYFMASA, wa s i dentical i $\mathrm{n}$ i ts $5 \mathrm{~N}$-terminal residues to the Nrp-1 targeted V1 peptide, which has the sequence ATWLPPR. Nrp-1 has been de monstrated $\mathrm{t} o$ be e xpressed i $\mathrm{n} b$ reast can cer, an $\mathrm{d} i$ ts ex pression $\mathrm{h}$ as $\mathrm{b}$ een confirmed in BT-474 cells (138). It was possible therefore, that the binding of Clone 51 was mediated by the $\mathrm{N}$-terminal residues homologous to V1. In order to test this, 51 and V1 were examined for similar ta rgeting characteristics in vitro and in vivo and several truncated versions of 51 were examined to determine the sequence that mediated BT-474 binding.

In vitro cell binding studies revealed that 51 bo und both B T-474 and HUVEC cells, while V1 only targeted HUVEC cells. Although BT-474 cells express Nrp1, it has been shown that they express the receptor at lower levels than HUVEC cells, which may explain the difference in binding of V 1 to B T-474 and HUVEC c ells (138). In fact, a 129 
monoclonal antibody targeting Nrp1 failed to elicit anti-proliferative effects with BT-474 cells in vitro, consistent with the observed results of V1 binding to BT-474 cells (139). However, this doe s not a ccount for the difference in cell binding b etween 51 a nd V 1. Although it was initially thought that the target of $51 \mathrm{~m}$ ay be $\mathrm{Nrp} 1$, the data presented here and previous analysis of V1 indicate this is not likely. In an earlier study examining the critical amino acids necessary for $\mathrm{V} 1$ binding, it was determined that the $\mathrm{C}$-terminal LPPR of V1 was the crucial sequence, as demonstrated by binding assays using alanine scanning a nd truncation $\mathrm{v}$ ariants, an $\mathrm{d} n$ uclear magnetic $\mathrm{r}$ esonance s pectrometry (140). Since peptide 51 does not contain the critical LPPR domain, the similarity between the 51 and V1 peptides may only be coincidental, or the ATWLP sequence by itself may not be enough to contribute to the binding properties of the peptide. Finally, truncated peptides were e xamined to de termine the role of shorter s equences, i ncluding A TWLP, on the binding of full length 51. It was determined that the full length peptide was required for optimal target affinity and specificity.

In addition to comparison of $\mathrm{V} 1$ and 51 in vitro, the in vivo data of this study was compared to previously publ ished V 1 in vivo data for pha rmacokinetics a nd imaging comparison. Unfortunately, V1 has only been tested as a ${ }^{99 \mathrm{~m}} \mathrm{Tc}$ radiolabeled peptide, and it was used with a different tumor model (141). Nevertheless, the in vivo analysis of V1 revealed higher tumor uptake ( $\sim 2 \% \mathrm{ID} / \mathrm{g})$ than 51 , but its tumor to muscle ratio was 0.22 , significantly lower than 51 . Although blood levels of the peptide were not given, it was reported that blood levels of the V 1 peptide prevented de tection of t umors b y S PECT imaging. Though not directly comparable, the stark differences in pharmacokinetic and 
SPECT i maging $\mathrm{p}$ roperties s uggest t hat 51 a nd V 1 do ha ve di fferent properties a nd targets. 


\section{Conclusion}

The data presented here provide evidence that ${ }^{111}$ In-DOTA-51 is a potential candidate for imaging B T-474 hum an breast tumor xenografts. A lthough the peptide's properties a re not $\mathrm{m}$ ediated b y a $\mathrm{N}$ rp 1 targeted s equence, the $\mathrm{p}$ eptide $\mathrm{n}$ onetheless ap pears to $\mathrm{t}$ arget tumor va sculature, a s de monstrated both in vitro and in vivo. In or der to progress the peptide further to the clinic, several questions must be addressed. Solid tumor uptake of the peptide is low, however it remains to be seen whether the vasculature uptake of the peptide will be sufficient for imaging in humans. Additionally, although BT-474 cells are a suitable base for developing a peptide targeted at resistance susceptible breast cancer, more in de pth models m ust be us ed to c onfirm that the pe ptide is i ndeed s pecific for targeted therapy resistant breast cancer. In that same regard, identification of the target of peptide 51, w hile not $\mathrm{t}$ rivial, $\mathrm{c}$ ould pr ovide i nformation $\mathrm{f}$ or $\mathrm{f}$ urther i nvestigation of proteins th at me diate $\mathrm{r}$ esistance. $\mathrm{R}$ egardless, the w ork he re de monstrates that in vivo phage display can be used to select peptides, which target a resistance susceptible breast cancer cell line, and the radiolabeled peptides can be used to identify xenografted tumors in vivo. 


\section{Acknowledgments}

The a uthors w ould 1 ike to a cknowledge the c ontributions of Jessica N ewton-Northup, Marie T. Dickerson and the VA Biomolecular Imaging Core. This material is based upon work supported by the Department of Veterans Affairs, Veterans Health Administration, Office o fR esearch and D evelopment, Biomedical Laboratory Research an d Development, C linical S ciences R esearch an d D evelopment i ncluding the Cooperative Studies Program, Rehabilitation Research and Development Service, and Health Services

Research and D evelopment $\mathrm{t}$ hrough a V A M erit A ward ( I01BX000964). Additional support provided by an NIBIB Training Grant NIBIB 5 T32 EB004822. 
136 


\section{REFERENCES}

1. Siegel R, Naishadham D, Jemal A. Cancer statistics, 2012. CA Cancer J Clin. 2012;62(1):10-29.

2. Bernstein L, Ross RK. Endogenous hormones and breast cancer risk. Epidemiol Rev. 1993;15(1):48-65.

3. Welch H, Schwartz LM, Woloshin S. Are increasing 5-year survival rates evidence of success against cancer? JAMA. 2000;283(22):2975-8.

4. Loft S, Poulsen HE. Cancer risk and oxidative DNA damage in man. J Mol Med. 1996;74(6):297-312.

5. Claus EB. Genetic analysis of breast cancer in the cancer and steroid hormone study. Am J Hum Genet. 1991;48(2):232.

6. Walboomers JMM. Human papillomavirus is a necessary cause of invasive cervical cancer worldwide. The Journal of pathology. 1999;189(1):12.

7. Pim D, Massimi P, Dilworth SM, Banks L. Activation of the protein kinase B pathway by the HPV-16 E7 oncoprotein occurs through a mechanism involving interaction with PP2A. Oncogene. 2005;24(53):7830-8.

8. Elmore S. Apoptosis: A Review of Programmed Cell Death. Toxicol Pathol. 2007;35(4):495-516.

9. Levine AJ. p53, the Cellular Gatekeeper for Growth and Division. Cell. 1997;88(3):323-31. 
10. Alroy I. The ErbB signaling network in embryogenesis and oncogenesis: signal diversification through combinatorial ligand-receptor interactions. FEBS Lett. 1997;410(1):83.

11. Folkman J, Long DM, Becker FF. Growth and metastasis of tumor in organ culture. Cancer. 1963;16(4):453-67.

12. Tannock IF. The relation between cell proliferation and the vascular system in a transplanted mouse mammary tumour. Br J Cancer. 1968;22(2):258-73. PMCID: 2008239.

13. Ausprunk DH, Folkman J. Migration and proliferation of endothelial cells in preformed and newly formed blood vessels during tumor angiogenesis. Microvasc Res. 1977;14(1):53-65.

14. Jain RK. Transport of Molecules in the Tumor Interstitium: A Review. Cancer Res. 1987;47(12):3039-51.

15. Liotta LA. Tumor Invasion and Metastases - Role of the Extracellular Matrix: Rhoads Memorial Award Lecture. Cancer Res. 1986;46(1):1-7.

16. Pantel K, Brakenhoff RH, Brandt B. Detection, clinical relevance and specific biological properties of disseminating tumour cells. Nat Rev Cancer. 2008;8(5):329-40.

17. Hagemeister FB, Buzdar AU, Luna MA, Blumenschein GR. Causes of death in breast cancer a clinicopathologic study. Cancer. 1980;46(1):162-7.

18. Paget S. The distribution of secondary growths in cancer of the breast. The Lancet. 1889;133(3421):571-3.

19. Schottenfeld D, Fraumeni Jr JF. Cancer epidemiology and prevention: Eastbourne, UK; WB Saunders Co; 1982.

20. Poola I, Abraham J, Marshalleck JJ, Yue Q, Fu SW, Viswanath L, et al. Molecular constitution of breast but not other reproductive tissues is rich in growth promoting molecules: A possible link to highest incidence of tumor growths. FEBS Lett. 2009;583(18):3069-75. 
21. Fisher CJ. Histopathology of breast cancer in relation to age. Br J Cancer. 1997;75(4):593.

22. Clemons M, Danson S, Howell A. Tamoxifen ('Nolvadex'): a review: Antitumour treatment. Cancer Treat Rev. 2002;28(4):165-80.

23. Holbro T, Hynes NE. ERBB RECEPTORS: Directing Key Signaling Networks Throughout Life. Annu Rev Pharmacol Toxicol. 2004;44(1):195-217.

24. Olayioye MA, Neve RM, Lane HA, Hynes NE. The ErbB signaling network: receptor heterodimerization in development and cancer. EMBO J. 2000;19(13):3159-67.

25. Hynes NE, Stern DF. The biology of erbB-2/neu/HER-2 and its role in cancer. Biochim Biophys Acta. 1994;1198(2-3):165-84.

26. Baselga J, Tripathy D, Mendelsohn J, Baughman S, Benz CC, Dantis L, et al. Phase II study of weekly intravenous recombinant humanized anti-p185HER2 monoclonal antibody in patients with HER2/neu-overexpressing metastatic breast cancer. J Clin Oncol. 1996;14(3):737-44.

27. Howlader N, Noone A, Krapcho M, Neyman N, Aminou R, Waldron W, et al. SEER cancer statistics review, 1975-2008. Bethesda, MD: National Cancer Institute. 2011;19.

28. Moss SM, Cuckle H, Evans A, Johns L, Waller M, Bobrow L. Effect of mammographic screening from age 40 years on breast cancer mortality at 10 years' follow-up: a randomised controlled trial. The Lancet. 2006;368(9552):2053-60.

29. Dang CV, Semenza GL. Oncogenic alterations of metabolism. Trends Biochem Sci. 1999;24(2):68-72.

30. Fischman AJ, Babich JW, Strauss HW. A Ticket to Ride: Peptide Radiopharmaceuticals. J Nucl Med. 1993;34(12):2253-63.

31. Schottelius M, Wester H-J. Molecular imaging targeting peptide receptors. Methods. 2009;48(2):161-77. 
32. Weissleder R. Molecular Imaging in Cancer. Science. 2006;312(5777):1168-71.

33. Witton CJ, Reeves JR, Going JJ, Cooke TG, Bartlett JMS. Expression of the HER 1-4 family of receptor tyrosine kinases in breast cancer. The Journal of pathology. 2003;200(3):290-7.

34. Yarden Y. Untangling the ErbB signalling network. Nature reviews Molecular cell biology. 2001;2(2):127.

35. Cho H-S, Mason K, Ramyar KX, Stanley AM, Gabelli SB, Denney DW, et al. Structure of the extracellular region of HER2 alone and in complex with the Herceptin Fab. Nature. 2003;421(6924):756-60.

36. Graus-Porta D, Beerli RR, Daly JM, Hynes NE. ErbB-2, the preferred heterodimerization partner of all ErbB receptors, is a mediator of lateral signaling. EMBO J. 1997;16(7):1647-55.

37. Baselga J, Gelmon KA, Verma S, Wardley A, Conte P, Miles D, et al. Phase II trial of pertuzumab and trastuzumab in patients with human epidermal growth factor receptor 2-positive metastatic breast cancer that progressed during prior trastuzumab therapy. J Clin Oncol. 2010;28(7):1138-44.

38. Franklin MC, Carey KD, Vajdos FF, Leahy DJ, de Vos AM, Sliwkowski MX. Insights into ErbB signaling from the structure of the ErbB2-pertuzumab complex. Cancer Cell. 2004;5(4):317-28.

39. Cavaliere A, Sidoni A, Scheibel M, Bellezza G, Brachelente G, Vitali R, et al. Biopathologic profile of breast cancer core biopsy: is it always a valid method? Cancer Lett. 2005;218(1):117-21.

40. Smith GP. Filamentous fusion phage: novel expression vectors that display cloned antigens on the virion surface. Science. 1985;228(4705):1315-7.

41. Thomas WD, Golomb M, Smith GP. Corruption of phage display libraries by target-unrelated clones: diagnosis and countermeasures. Anal Biochem. 2010;407(2):23740 . 
42. Zou J, Glinsky VV, Landon LA, Matthews L, Deutscher SL. Peptides specific to the galectin-3 carbohydrate recognition domain inhibit metastasis-associated cancer cell adhesion. Carcinogenesis. 2005;26(2):309-18.

43. Karasseva NG, Glinsky VV, Chen NX, Komatireddy R, Quinn TP. Identification and Characterization of Peptides That Bind Human ErbB-2 Selected from a Bacteriophage Display Library. J Protein Chem. 2002;21(4):287-96.

44. Peletskaya E, Glinsky G, Deutscher S, Quinn T. Identification of peptide sequences that bind the Thomsen-Friedenreich cancer-associated glycoantigen from bacteriophage peptide display libraries. Mol Divers. 1996;2(1):13-8.

45. Ruoslahti E. RGD AND OTHER RECOGNITION SEQUENCES FOR INTEGRINS. Annu Rev Cell Dev Biol. 1996;12(1):697-715.

46. Day JW, Kim CH, Smider VV, Schultz PG. Identification of metal ion binding peptides containing unnatural amino acids by phage display. Bioorg Med Chem Lett. 2013(0).

47. Kumar SR, Deutscher SL. 111In-Labeled Galectin-3-Targeting Peptide as a SPECT Agent for Imaging Breast Tumors. J Nucl Med. 2008;49(5):796-803.

48. Kumar SR, Quinn TP, Deutscher SL. Evaluation of an 111 In-Radiolabeled Peptide as a Targeting and Imaging Agent for ErbB-2 Receptor-Expressing Breast Carcinomas. Clin Cancer Res. 2007;13(20):6070-9.

49. Arap W, Kolonin MG, Trepel M, Lahdenranta J, Cardo-Vila M, Giordano RJ, et al. Steps toward mapping the human vasculature by phage display. Nat Med. 2002;8(2):121-7.

50. Newton JR, Kelly KA, Mahmood U, Weissleder R, Deutscher SL. In vivo selection of phage for the optical imaging of PC-3 human prostate carcinoma in mice. Neoplasia. 2006;8(9):772-80. PMCID: 1584300.

51. Lobo ED, Hansen RJ, Balthasar JP. Antibody pharmacokinetics and pharmacodynamics. J Pharm Sci. 2004;93(11):2645-68. 
52. Yeh ET, Tong AT, Lenihan DJ, Yusuf SW, Swafford J, Champion C, et al. Cardiovascular complications of cancer therapy diagnosis, pathogenesis, and management. Circulation. 2004;109(25):3122-31.

53. Chen J, Cheng Z, Miao Y, Jurisson SS, Quinn TP. $\alpha$-melanocyte-stimulating hormone peptide analogs labeled with technetium-99m and indium-111 for malignant melanoma targeting. Cancer. 2002;94(S4):1196-201.

54. Hoffman TJ, Gali H, Smith CJ, Sieckman GL, Hayes DL, Owen NK, et al. Novel Series of 111In-Labeled Bombesin Analogs as Potential Radiopharmaceuticals for Specific Targeting of Gastrin-Releasing Peptide Receptors Expressed on Human Prostate Cancer Cells. J Nucl Med. 2003;44(5):823-31.

55. Olsen JO, Pozderac RV, Hinkle G, Hill T, O'Dorisio TM, Schirmer WJ, et al. Somatostatin receptor imaging of neuroendocrine tumors with indium-111 pentetreotide (Octreoscan). Semin Nucl Med. 1995;25(3):251-61.

56. McDonald DM, Choyke PL. Imaging of angiogenesis: from microscope to clinic. Nat Med. 2003;9(6):713-25.

57. Koivunen E, Gay DA, Ruoslahti E. Selection of peptides binding to the alpha 5 beta 1 integrin from phage display library. J Biol Chem. 1993;268(27):20205-10.

58. Bausch D, Thomas S, Mino-Kenudson M, Fernández-del CC, Bauer TW, Williams M, et al. Plectin-1 as a Novel Biomarker for Pancreatic Cancer. Clin Cancer Res. 2011;17(2):302-9.

59. Maecke HR, Riesen A, Ritter W. The molecular structure of indium-DTPA. Journal of nuclear medicine: official publication, Society of Nuclear Medicine. 1989;30(7):1235-9.

60. Harris TD, Sworin M, Williams N, Rajopadhye M, Damphousse PR, Glowacka D, et al. Synthesis of Stable Hydrazones of a Hydrazinonicotinyl-Modified Peptide for the Preparation of 99mTc-Labeled Radiopharmaceuticals. Bioconjug Chem. 1999;10(5):808-14.

61. Prasanphanich AF, Nanda PK, Rold TL, Ma L, Lewis MR, Garrison JC, et al. [64Cu-NOTA-8-Aoc-BBN (7-14) NH2] targeting vector for positron-emission 
tomography imaging of gastrin-releasing peptide receptor-expressing tissues. Proceedings of the National Academy of Sciences. 2007;104(30):12462-7.

62. Sun X, Wuest M, Weisman GR, Wong EH, Reed DP, Boswell CA, et al. Radiolabeling and In Vivo Behavior of Copper-64-Labeled Cross-Bridged Cyclam Ligands. J Med Chem. 2001;45(2):469-77.

63. De Leon-Rodriguez LM, Kovacs Z. The Synthesis and Chelation Chemistry of DOTA-Peptide Conjugates. Bioconjug Chem. 2007;19(2):391-402.

64. Mariani G, Bruselli L, Kuwert T, Kim EE, Flotats A, Israel O, et al. A review on the clinical uses of SPECT/CT. Eur J Nucl Med Mol Imaging. 2010;37(10):1959-85.

65. Liu S, Edwards DS. 99mTc-labeled small peptides as diagnostic radiopharmaceuticals. Chem Rev. 1999;99(9):2235-68.

66. Zeglis BM, Lewis JS. A practical guide to the construction of radiometallated bioconjugates for positron emission tomography. Dalton Transactions. 2011;40(23):6168-95.

67. Bar-Shalom R, Yefremov N, Guralnik L, Gaitini D, Frenkel A, Kuten A, et al. Clinical performance of PET/CT in evaluation of cancer: additional value for diagnostic imaging and patient management. J Nucl Med. 2003;44(8):1200-9.

68. Milenic DE, Yokota T, Filpula DR, Finkelman MAJ, Dodd SW, Wood JF, et al. Construction, Binding Properties, Metabolism, and Tumor Targeting of a Single-Chain Fv Derived from the Pancarcinoma Monoclonal Antibody CC49. Cancer Res. 1991;51(23 Part 1):6363-71.

69. Fujimori K. A modeling analysis of monoclonal antibody percolation through tumors: a binding-site barrier. J Nucl Med. 1990;31(7):1191.

70. Landon LA, Zou J, Deutscher SL. Is Phage Display Technology on Target for Developing Peptide-Based Cancer Drugs? Current Drug Discovery Technologies. 2004;1(2):113-32. 
71. Landon LA, Deutscher SL. Combinatorial discovery of tumor targeting peptides using phage display. J Cell Biochem. 2003;90(3):509-17.

72. Ruoslahti E. Targeting tumor vasculature with homing peptides from phage display. Semin Cancer Biol. 2000;10(6):435-42.

73. Deutscher SL, Figueroa SD, Kumar SR. 111In-labeled KCCYSL peptide as an imaging probe for ErbB-2-expressing ovarian carcinomas. Journal of Labelled Compounds and Radiopharmaceuticals. 2009;52(14):583-90.

74. Kocks C, Rajewsky K. Stepwise intraclonal maturation of antibody affinity through somatic hypermutation. Proc Natl Acad Sci U S A. 1988;85(21):8206-10.

75. Landon LA, Peletskaya EN, Glinsky VV, Karasseva N, Quinn TP, Deutscher SL. Combinatorial Evolution of High-Affinity Peptides That Bind to the ThomsenFriedenreich Carcinoma Antigen. J Protein Chem. 2003;22(2):193-204.

76. Smith GP. G.P. Smith Phage Display Website. 2006 [updated 2006 3/5/2006; cited]; Available from:

http://www.biosci.missouri.edu/smithGP/PhageDisplayWebsite/PhageDisplayWebsiteInd ex.html.

77. Altschul SF, Gish W, Miller W, Myers EW, Lipman DJ. Basic local alignment search tool. J Mol Biol. 1990;215(3):403-10.

78. Huang J, Ru B, Li S, Lin H, Guo F-B. SAROTUP: scanner and reporter of targetunrelated peptides. BioMed Research International. 2010;2010.

79. Molina MA, Codony-Servat J, Albanell J, Rojo F, Arribas J, Baselga J. Trastuzumab (Herceptin), a humanized anti-HER2 receptor monoclonal antibody, inhibits basal and activated HER2 ectodomain cleavage in breast cancer cells. Cancer Res. 2001;61(12):4744-9.

80. Zhang X, Cabral P, Bates M, Pablo Gambini J, Fernandez M, Calzada V, et al. In Vitro and In Vivo Evaluation of [99mTc (CO) 3]-Radiolabeled ErbB-2-Targeting Peptides for Breast Carcinoma Imaging. Current Radiopharmaceuticals. 2010;3(4):30821. 
81. Vegt E, de Jong M, Wetzels JFM, Masereeuw R, Melis M, Oyen WJG, et al. Renal Toxicity of Radiolabeled Peptides and Antibody Fragments: Mechanisms, Impact on Radionuclide Therapy, and Strategies for Prevention. J Nucl Med. 2010;51(7):104958.

82. Miao Y, Fisher DR, Quinn TP. Reducing renal uptake of 90Y- and 177Lu-labeled alpha-melanocyte stimulating hormone peptide analogues. Nucl Med Biol. 2006;33(6):723-33.

83. Froidevaux S, Eberle AN, Christe M, Sumanovski L, Heppeler A, Schmitt JS, et al. Neuroendocrine tumor targeting: Study of novel gallium-labeled somatostatin radiopeptides in a rat pancreatic tumor model. Int J Cancer. 2002;98(6):930-7.

84. Good S, Walter MA, Waser B, Wang X, Müller-Brand J, Béhé MP, et al. Macrocyclic chelator-coupled gastrin-based radiopharmaceuticals for targeting of gastrin receptor-expressing tumours. Eur J Nucl Med. 2008;35(10):1868-77.

85. Chen J, Cheng Z, Owen NK, Hoffman TJ, Miao Y, Jurisson SS, et al. Evaluation of an 111In-DOTA-Rhenium Cyclized $\alpha$-MSH Analog: A Novel Cyclic-Peptide Analog with Improved Tumor-Targeting Properties. J Nucl Med. 2001;42(12):1847-55.

86. Deutscher SL. Phage display in molecular imaging and diagnosis of cancer. Chem Rev. 2010;110(5):3196-211.

87. Derda R, Tang S, Li SC, Ng S, Matochko W, Jafari M. Diversity of PhageDisplayed Libraries of Peptides during Panning and Amplification. Molecules. 2011;16(2):1776-803.

88. Yu D, Hung M-C. Overexpression of ErbB2 in cancer and ErbB2-targeting strategies. Oncogene. 2000;19(53):6115.

89. Krenning EP, Kwekkeboom DJ, Bakker WH, Breeman WAP, Kooij PPM, Oei HY, et al. Somatostatin receptor scintigraphy with [111 In-DTPA-d-Phe1]- and [123ITyr3]-octreotide: the Rotterdam experience with more than 1000 patients. Eur J Nucl Med. 1993;20(8):716-31.

90. Béhé M, Becker W, Gotthardt M, Angerstein C, Behr T. Improved kinetic stability of DTPA-dGlu as compared with conventional monofunctional DTPA in 
chelating indium and yttrium: preclinical and initial clinical evaluation of radiometal labelled minigastrin derivatives. Eur J Nucl Med Mol Imaging. 2003;30(8):1140-6.

91. Ferro-Flores G, de Murphy CA, Rodr'guez-Corte`s J, Pedraza-Lo `pez M, Ram 'rez-Iglesias MaT. Preparation and evaluation of 99mTc-EDDA/HYNIC-[Lys3]bombesin for imaging gastrin-releasing peptide receptor-positive tumours. Nucl Med Commun. 2006;27(4):371-6

92. Thakur ML, Aruva MR, Gariepy J, Acton P, Rattan S, Prasad S, et al. PET Imaging of Oncogene Overexpression Using 64Cu-Vasoactive Intestinal Peptide (VIP) Analog: Comparison with 99mTc-VIP Analog. J Nucl Med. 2004;45(8):1381-9.

93. Rolleman E, Valkema R, de Jong M, Kooij P, Krenning E. Safe and effective inhibition of renal uptake of radiolabelled octreotide by a combination of lysine and arginine. Eur J Nucl Med Mol Imaging. 2003;30(1):9-15.

94. Vegt E, van Eerd JEM, Eek A, Oyen WJG, Wetzels JFM, de Jong M, et al. Reducing Renal Uptake of Radiolabeled Peptides Using Albumin Fragments. J Nucl Med. 2008;49(9):1506-11.

95. Shojaei F. Anti-angiogenesis therapy in cancer: Current challenges and future perspectives. Cancer Lett. 2012;320(2):130-7.

96. Folkman J. Tumor angiogenesis: therapeutic implications. N Engl J Med. 1971;285(21):1182-6.

97. Ruoslahti E, Rajotte D. An address system in the vasculature of normal tissues and tumors. Annu Rev Immunol. 2000;18(1):813-27.

98. Jain RK. The Eugene M. Landis Award Lecture 1996. Delivery of molecular and cellular medicine to solid tumors. Microcirculation (New York, NY : 1994). 1997;4(1):123.

99. Weis SM, Cheresh DA. Tumor angiogenesis: molecular pathways and therapeutic targets. Nat Med. 2011;17(11):1359-70. 
100. Coukos G. Novel surface targets and serum biomarkers from the ovarian cancer vasculature. Cancer biology \& therapy. 2011;12(3):1.

101. DeRisi J, Penland L, Brown PO, Bittner ML, Meltzer PS, Ray M, et al. Use of a cDNA microarray to analyse gene expression patterns in human cancer. Nat Genet. 1996;14(4):457-60.

102. Li J-L, Harris AL. The Potential of New Tumor Endothelium-Specific Markers for the Development of Antivascular Therapy. Cancer Cell. 2007;11(6):478-81.

103. Bild AH, Yao G, Chang JT, Wang Q, Potti A, Chasse D, et al. Oncogenic pathway signatures in human cancers as a guide to targeted therapies. Nature. 2006;439(7074):353-7.

104. Yeung G, Mulero JJ, Berntsen RP, Loeb DB, Drmanac R, Ford JE. Cloning of a Novel Epidermal Growth Factor Repeat Containing Gene EGFL6: Expressed in Tumor and Fetal Tissues. Genomics. 1999;62(2):304-7.

105. Buckanovich RJ, Sasaroli D, O'Brien-Jenkins A, Botbyl J, Hammond R, Katsaros $\mathrm{D}$, et al. Tumor Vascular Proteins As Biomarkers in Ovarian Cancer. J Clin Oncol. 2007;25(7):852-61.

106. Wang X, Gong Y, Wang D, Xie Q, Zheng M, Zhou Y, et al. Analysis of gene expression profiling in meningioma: deregulated signaling pathways associated with meningioma and egfl6 overexpression in benign meningioma tissue and serum. PLoS ONE. 2012;7(12):e52707.

107. Chim SM, Qin A, Tickner J, Pavlos N, Davey T, Wang H, et al. EGFL6 Promotes Endothelial Cell Migration and Angiogenesis through the Activation of Extracellular Signal-regulated Kinase. J Biol Chem. 2011;286(25):22035-46.

108. Jung E, Lee N, Kang S-K, Choi S-H, Kim D, Park K, et al. Identification of tissue-specific targeting peptide. J Comput Aided Mol Des. 2012:1-9.

109. Presta LG, Chen H, O'Connor SJ, Chisholm V, Meng YG, Krummen L, et al. Humanization of an anti-vascular endothelial growth factor monoclonal antibody for the therapy of solid tumors and other disorders. Cancer Res. 1997;57(20):4593-9. 
110. Holash J, Davis S, Papadopoulos N, Croll SD, Ho L, Russell M, et al. VEGFTrap: A VEGF blocker with potent antitumor effects. Proc Natl Acad Sci U S A. 2002;99(17):11393-8.

111. O'Farrell AM, Abrams TJ, Yuen HA, Ngai TJ, Louie SG, Yee KWH, et al. SU11248 is a novel FLT3 tyrosine kinase inhibitor with potent activity in vitro and in vivo. Blood. 2003;101(9):3597-605.

112. Langmuir PB, Yver A. Vandetanib for the treatment of thyroid cancer. Clin Pharmacol Ther. 2012;91(1):71-80.

113. Kerbel RS. Tumor Angiogenesis. N Engl J Med. 2008;358(19):2039-49.

114. Cascone T, Herynk MH, Xu L, Du Z, Kadara H, Nilsson MB, et al. Upregulated stromal EGFR and vascular remodeling in mouse xenograft models of angiogenesis inhibitor-resistant human lung adenocarcinoma. J Clin Invest. 2011;121(4):1313-28.

115. Shojaei F, Wu X, Malik AK, Zhong C, Baldwin ME, Schanz S, et al. Tumor refractoriness to anti-VEGF treatment is mediated by $\mathrm{CD} 11 \mathrm{~b}+\mathrm{Gr} 1+$ myeloid cells. Nat Biotechnol. 2007;25(8):911-20.

116. Sánchez-Martín D, Martínez-Torrecuadrada J, Teesalu T, Sugahara KN, AlvarezCienfuegos A, Ximénez-Embún P, et al. Proteasome activator complex PA28 identified as an accessible target in prostate cancer by in vivo selection of human antibodies. Proceedings of the National Academy of Sciences. 2013.

117. Bjornsti M-A, Houghton PJ. Lost in translation: Dysregulation of cap-dependent translation and cancer. Cancer Cell. 2004;5(6):519-23.

118. Koumenis C, Naczki C, Koritzinsky M, Rastani S, Diehl A, Sonenberg N, et al. Regulation of Protein Synthesis by Hypoxia via Activation of the Endoplasmic Reticulum Kinase PERK and Phosphorylation of the Translation Initiation Factor eIF2 $\alpha$. Mol Cell Biol. 2002;22(21):7405-16.

119. Carmeliet P, Jain RK. Angiogenesis in cancer and other diseases. Nature. 2000;407(6801):249-57. 
120. Haubner R, Beer A, Wang H, Chen X. Positron emission tomography tracers for imaging angiogenesis. Eur J Nucl Med Mol Imaging. 2010;37(1):86-103.

121. Slamon DJ, Leyland-Jones B, Shak S, Fuchs H, Paton V, Bajamonde A, et al. Use of Chemotherapy plus a Monoclonal Antibody against HER2 for Metastatic Breast Cancer That Overexpresses HER2. N Engl J Med. 2001;344(11):783-92.

122. Abe O, Abe R, Enomoto Kt, Kikuchi K, Koyama H, Nomura Y, et al. Tamoxifen for early breast cancer: an overview of the randomised trials. Lancet. 1998;351(9114):1451-67.

123. Borg Å, Baldetorp B, Fernö M, Killander D, Olsson H, Ryden S, et al. ERBB2 amplification is associated with tamoxifen resistance in steroid-receptor positive breast cancer. Cancer Lett. 1994;81(2):137-44.

124. Berns K, Horlings HM, Hennessy BT, Madiredjo M, Hijmans EM, Beelen K, et al. A Functional Genetic Approach Identifies the PI3K Pathway as a Major Determinant of Trastuzumab Resistance in Breast Cancer. Cancer Cell. 2007;12(4):395-402.

125. Doane AS, Danso M, Lal P, Donaton M, Zhang L, Hudis C, et al. An estrogen receptor-negative breast cancer subset characterized by a hormonally regulated transcriptional program and response to androgen. Oncogene. 2006;25(28):3994-4008.

126. Charafe-Jauffret E, Ginestier C, Monville F, Finetti P, Adelaide J, Cervera N, et al. Gene expression profiling of breast cell lines identifies potential new basal markers. Oncogene. 2005;25(15):2273-84.

127. Tang Y, Wang J, Scollard DA, Mondal H, Holloway C, Kahn HJ, et al. Imaging of HER2/neu-positive BT-474 human breast cancer xenografts in athymic mice using < sup $>111</$ sup $>$ In-trastuzumab (Herceptin) Fab fragments. Nucl Med Biol. 2005;32(1):51-8.

128. van Slooten HJ, Bonsing BA, Hiller AJ, Colbern GT, van Dierendonck JH, Cornelisse CJ, et al. Outgrowth of BT-474 human breast cancer cells in immune-deficient mice: a new in vivo model for hormone-dependent breast cancer. Br J Cancer.

1995;72(1):22-30. 
129. Chung YL, Sheu ML, Yang SC, Lin CH, Yen SH. Resistance to tamoxifen-induced apoptosis is associated with direct interaction between Her2/neu and cell membrane estrogen receptor in breast cancer. Int J Cancer. 2002;97(3):306-12.

130. Scott J, Smith G. Searching for peptide ligands with an epitope library. Science. 1990;249(4967):386-90.

131. Larimer B, Thomas W, Smith G, Deutscher S. Affinity Maturation of an ERBB2Targeted SPECT Imaging Peptide by In Vivo Phage Display. Mol Imaging Biol. 2014:110.

132. Rooy I, Cakir-Tascioglu S, Couraud P-O, Romero I, Weksler B, Storm G, et al. Identification of Peptide Ligands for Targeting to the Blood-Brain Barrier. Pharm Res. 2010;27(4):673-82.

133. Matsubara T, Onishi A, Saito T, Shimada A, Inoue H, Taki T, et al. Sialic AcidMimic Peptides As Hemagglutinin Inhibitors for Anti-Influenza Therapy. J Med Chem. 2010;53(11):4441-9.

134. Yao Z-J, Kao MC, Chung MC. Epitope identification by polyclonal antibody from phage-displayed random peptide library. J Protein Chem. 1995;14(3):161-6.

135. Binetruy-Tournaire R, Demangel C, Malavaud B, Vassy R, Rouyre S, Kraemer $\mathrm{M}$, et al. Identification of a peptide blocking vascular endothelial growth factor (VEGF)mediated angiogenesis. EMBO J. 2000;19(7):1525-33.

136. Barr M, Byrne A, Duffy A, Condron C, Devocelle M, Harriott P, et al. A peptide corresponding to the neuropilin-1-binding site on VEGF165 induces apoptosis of neuropilin-1-expressing breast tumour cells. Br J Cancer. 2005;92(2):328-33.

137. Kute T, Lack CM, Willingham M, Bishwokama B, Williams H, Barrett K, et al. Development of Herceptin resistance in breast cancer cells. Cytometry Part A. 2004;57A(2):86-93.

138. Glinka Y, Mohammed N, Subramaniam V, Jothy S, Prud'homme GJ. Neuropilin1 is expressed by breast cancer stem-like cells and is linked to NF- $\mathrm{kB}$ activation and tumor sphere formation. Biochem Biophys Res Commun. 2012;425(4):775-80. 
139. Pan Q, Chanthery Y, Liang W-C, Stawicki S, Mak J, Rathore N, et al. Blocking Neuropilin-1 Function Has an Additive Effect with Anti-VEGF to Inhibit Tumor Growth. Cancer Cell. 2007;11(1):53-67.

140. Starzec A, Ladam P, Vassy R, Badache S, Bouchemal N, Navaza A, et al. Structure-function analysis of the antiangiogenic ATWLPPR peptide inhibiting VEGF165 binding to neuropilin-1 and molecular dynamics simulations of the ATWLPPR/neuropilin-1 complex. Peptides. 2007;28(12):2397-402.

141. Perret GY, Starzec A, Hauet N, Vergote J, Le Pecheur M, Vassy R, et al. In vitro evaluation and biodistribution of a 99mTc-labeled anti-VEGF peptide targeting neuropilin-1. Nucl Med Biol. 2004;31(5):575-81. 


\section{VITA}

Ben Larimer was born September $26^{\text {th }}$, 1986, in Normal, Illinois. In May 2005, he graduated from O'Fallon Township High School in O'Fallon, Illinois. He received his Bachelor of Science degree in Biochemistry from the University of Missouri in May 2009. He will complete his Ph.D. in Biochemistry in May 2014 from the University of Missouri. 